Wh.

$$
\begin{gathered}
\text { MA } 07989 \\
0511
\end{gathered}
$$

\section{TRANSPORTATION SYSTEM RISK ASSESSMENT (TSRA) BOUNDING RELEASE MODEL}

J. C. Anderson

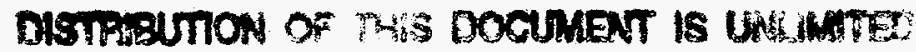

MANAGED BY LOCKUEED WARTN ENERGY SYSTEMS, INC. FOR THE UNIED STATES DEPARTWENT OF ENERGY 


\section{DISCLAIMER}

This report was prepared as an account of work sponsored by an agency of the United States Government. Neither the United States Government nor any agency thereof, nor any of their employees, makes any warranty, express or implied, or assumes any legal liability or responsibility for the accuracy, completeness, or usefulness of any information, apparatus, product, or process disclosed, or represents that its use would not infringe privately owned rights. Reference herein to any specific commercial product, process, or service by trade name, trademark, manufacturer, or otherwise, does not necessarily constitute or imply its endorsement, recommendation, or favoring by the United States Government or any agency thereof. The views and opinions of authors expressed herein do not necessarily state or reflect those of the United States Government or any agency thereof. 


\section{DISCLAIMER}

Portions of this document may be illegible in electronic image products. Images are produced from the best available original document. 
Lockheed Martin Energy Systems, Inc., Central Engineering Services Specialty Engineering Services

\title{
TRANSPORTATION SYSTEM RISK ASSESSMENT (TSRA) BOUNDING RELEASE MODEL
}

\author{
Prepared by J. C. Anderson
}

\author{
October 1997 \\ Prepared for the Oak Ridge Y-12 Plant \\ Nuclear Packaging Systems \\ Y-12 Defense Programs Division
}

Prepared by

LOCKHEED MARTIN ENERGY SYSTEMS, INC.

managing the

East Tennessee Technology Park

Oak Ridge Y-12 Plant

under Contract DE-AC05-84OR21400

for the

U.S. DEPARTMENT OF ENERGY 


\section{DISCLAIMER}

This report was prepared as an account of work sponsored by an agency of the United States Government. Neither the United States Government nor any agency thereof, nor any of their employees, makes any warranty, express or implied, or assumes any legal liability or responsibility for the accuracy, completeness, or usefulness of any information, apparatus, product, or process disclosed, or represents that its use would not infringe privately owned rights. Reference herein to any specific commercial product, process, or service by trade name, trademark, manufacturer, or otherwise, does not necessarily constitute or imply its endorsement, recommendation, or favoring by the United States Government or any agency thereof. The views and opinions of authors expressed herein do not necessarily state or reflect those of the United States Government or any agency thereof. 


\section{CONTENTS}

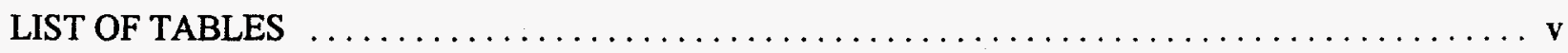

ACKNOWLEDGMENTS $\ldots \ldots \ldots \ldots \ldots \ldots \ldots \ldots \ldots \ldots \ldots \ldots \ldots \ldots \ldots \ldots \ldots \ldots$ vii

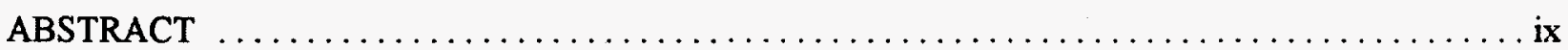

1. INTRODUCTION $\ldots \ldots \ldots \ldots \ldots \ldots \ldots \ldots \ldots \ldots \ldots \ldots \ldots \ldots \ldots \ldots \ldots \ldots \ldots \ldots \ldots$

2. DESCRIPTION OF NUMERICAL MODEL $\ldots \ldots \ldots \ldots \ldots \ldots \ldots \ldots \ldots \ldots \ldots \ldots \ldots$

2.1 PROGRAM DEFAULT VALUES $\ldots \ldots \ldots \ldots \ldots \ldots \ldots \ldots \ldots \ldots \ldots \ldots \ldots \ldots \ldots \ldots \ldots \ldots \ldots \ldots$

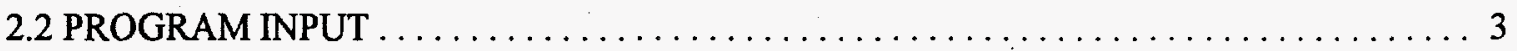

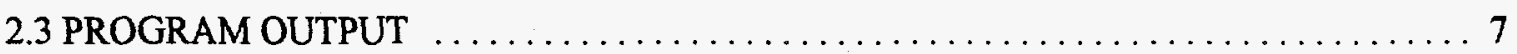

3. MATERIALS CONSIDERED IN MODEL $\ldots \ldots \ldots \ldots \ldots \ldots \ldots \ldots \ldots \ldots \ldots \ldots$

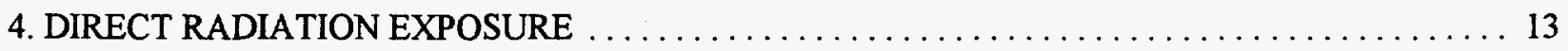

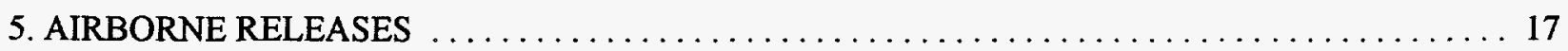

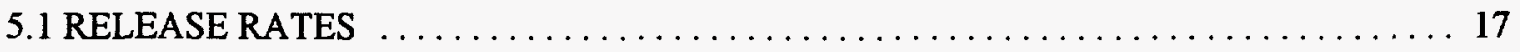

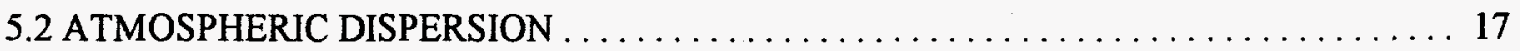

5.3 RADIOLOGICAL CONSEQUENCES OF INHALATION $\ldots \ldots \ldots \ldots \ldots \ldots \ldots \ldots .22$

5.4 CHEMICAL CONSEQUENCES OF INHALATION $\ldots \ldots \ldots \ldots \ldots \ldots \ldots \ldots \ldots \ldots \ldots$

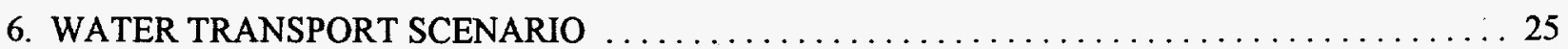

6.1 RADIOLOGICAL CONSEQUENCES OF INGESTION $\ldots \ldots \ldots \ldots \ldots \ldots \ldots \ldots \ldots$

6.2 CHEMICAL CONSEQUENCES OF INGESTION $\ldots \ldots \ldots \ldots \ldots \ldots \ldots \ldots \ldots \ldots$

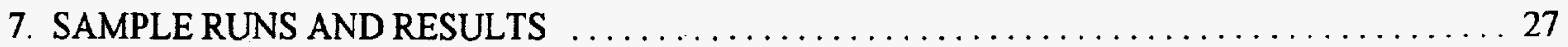

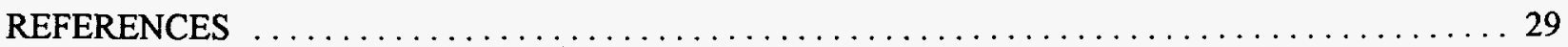

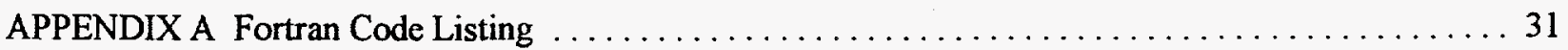

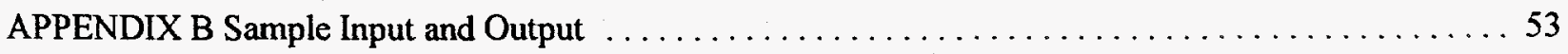

APPENDIX C Letters from Local Water Treatment Plants $\ldots \ldots \ldots \ldots \ldots \ldots \ldots \ldots \ldots \ldots$ 



\section{LIST OF TABLES}

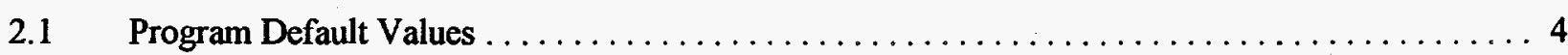

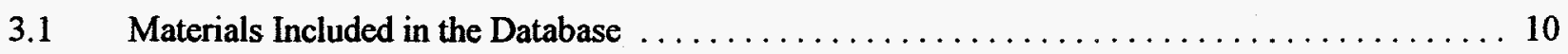

3.2 Isotopic Compositions of Radiological Materials $\ldots \ldots \ldots \ldots \ldots \ldots \ldots \ldots \ldots \ldots \ldots$

4.1 Response Terms for All Nuclides $\ldots \ldots \ldots \ldots \ldots \ldots \ldots \ldots \ldots \ldots \ldots \ldots \ldots \ldots$

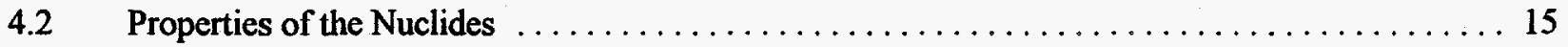

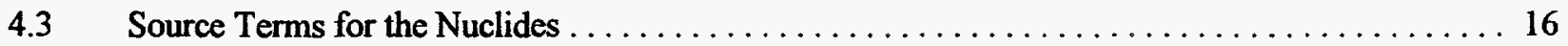

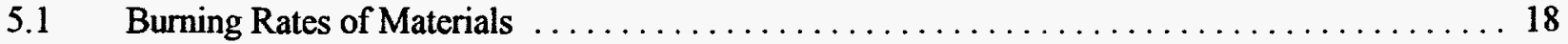

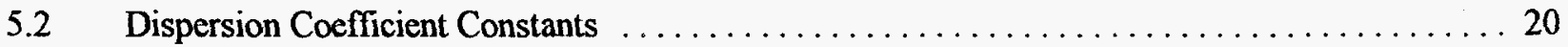

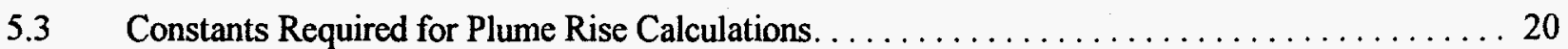

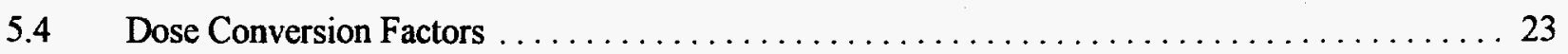

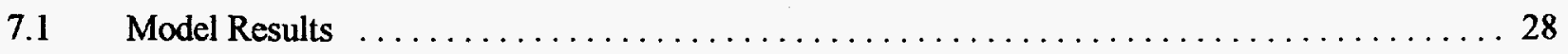





\section{ACKNOWLEDGMENTS}

The author of this report acknowledges, with appreciation, the support of B. L. Broadhead of the Nuclear Engineering Applications Section and S. N. Cramer of the Radiation Shielding Information Center, both of which are a part of the Computational Physics and Engineering Division at Lockheed Martin Energy Research, R. A. Just of the Facility Safety Analysis Department in the Central Engineering Services Division, C. P. Kerr formerly of the Engineering Analysis Department in the Central Engineering Services Division and D. A. Tollefson of the Health, Safety, Environment and Accountability Division toward the development of the TSRA Bounding Release Model.

The author also acknowledges the support of S. G. Bloom, J. H. Clinton and W. R. Williams of the Engineering Analysis Department in the Central Engineering Services Division for reviewing the document and providing original ideas and comments as this work progressed.

This report was sponsored by and funding provided through DOE/AL Nuclear Explosives Safety Division (NESD) and Y-12 Nuclear Packaging Systems (NPS). 



\begin{abstract}
Transportation System Risk Assessments (TSRAs) document the compliance of proposed shipments of nuclear components with applicable federal regulations as well as the associated risks involved. If a relatively simple bounding analysis can show that the consequences resulting from a worst case scenario are acceptably low, a more time intensive and costly risk analysis can be avoided. Therefore, a bounding release FORTRAN model has been developed to determine the consequences of a worst case non-criticality transportation accident. The consequences of three conservative bounding accidents are determined by the model: 1) direct radiation exposure, 2) airborne release of radiological and/or hazardous solid material, and 3) release of radiological and/or hazardous solid material into a waterway and subsequent uptake by an individual through drinking water. Program output includes the direct radiation exposure (mrem), maximum downwind concentration $\left(\mathrm{mg} / \mathrm{m}^{3}\right)$, radiation dose $(\mathrm{mrem})$ received as a result of the postulated airborne release of radiological material, intake $(\mathrm{mg})$ due to inhalation, radiation dose $(\mathrm{mrem})$ received by an individual resulting from a release of radiological material into a waterway and uptake into drinking water, and uptake (mg) due to ingestion. This report documents the methodologies and correlations used in the numerical model to perform the bounding consequence calculations.
\end{abstract}





\section{INTRODUCTION}

The Nuclear Explosive Safety Division (NESD) of the Department of Energy, Albuquerque Area Office (DOE-AL) is responsible for evaluating Transportation System Risk Assessments (TSRAs). TSRAs document the compliance of proposed shipments of nuclear components with applicable federal regulations as well as the associated risks involved. If a relatively simple bounding analysis can show that the consequences resulting from a worst case scenario are acceptably low, a more time intensive and costly risk analysis can be avoided. Therefore, the purpose of this project is to develop a model which will determine the consequences of a worst case non-criticality transportation accident. It is expected that if a criticality accident is credible, modifications will be required prior to shipment to prevent this from occurring. Therefore, analysis of a postulated criticality incident is not considered in this model. model:

The consequences of the following three conservative bounding accidents are determined by the

(1) Direct radiation exposure,

(2) Airborne release of radiological and/or hazardous solid material,

(3) Release of radiological and/or hazardous solid material into a waterway and subsequent uptake by an individual through drinking water.

Historically, the Nuclear Regulatory Commission has considered only radiological hazards in licensing the transport of radiological material because the U. S. Department of Transportation considers licensing requirements of nonradiological (i.e., chemically toxic) materials. A TSRA is prepared when it is not possible to meet the licensing requirements of 10 CFR 71 . These requirements are based primarily on consideration of radiological hazards. For completeness, this report provides information for assessing the effects of chemical toxicity.

For the direct radiation calculation, it is assumed that $100 \%$ of the potentially hazardous material is exposed and unshielded. Excluding a criticality event, a fire or explosion are the only plausible mechanisms identified for dispersing significant amounts of solid hazardous materials into the atmosphere. At the present time, the model only calculates the consequences resulting from a fire. The fire is assumed to be fueled by the gasoline or diesel fuel present in the transport vehicle. Both radiological and chemical effects are determined. The third accident scenario involves the spill or release of hazardous material into a waterway and the subsequent uptake by an individual. Both radiological and chemical consequences will be determined for this scenario. The model conservatively neglects any mitigative or emergency response actions such as notification of possible danger, efforts to extinguish the fire, actions to prevent people from drinking contaminated water, etc. The model also assumes that an individual remains at a given location throughout the duration of the exposure.

A FORTRAN model has been constructed to evaluate the accident scenarios described above. Output from the program includes:

(1) Direct radiation exposure (mrem) to the Maximally Exposed Individual,

(2) Maximum downwind concentration $\left(\mathrm{mg} / \mathrm{m}^{3}\right)$ and the product of concentration and exposure time $\left(\mathrm{mg}-\mathrm{hr} / \mathrm{m}^{3}\right)$,

(3) Maximum radiation dose (mrem) to the Maximally Exposed Individual as a result of the postulated airborne release of radiological material, 
(4) Maximum intake (mg) the Maximally Exposed Individual receives as a result of the postulated airborne release of toxic material,

(5) Radiation dose (mrem) received by an individual resulting from a release of radiological material into a waterway and uptake into drinking water,

(6) Uptake ( $\mathrm{mg}$ ) received by an individual resulting from the release of toxic material into a waterway.

This report presents the correlations, assumptions and other background information required to perform the bounding consequence calculations. In addition, a brief discussion is presented regarding the construction and use of the numerical model. Results from sample runs for all the materials of interest are also presented and discussed. 


\section{DESCRIPTION OF NUMERICAL MODEL}

A FORTRAN model has been constructed to perform bounding analysis calculations for a worst case non-criticality transportation accident. A complete listing of the FORTRAN model is presented in Appendix A. The model consists of the following program units:

(1) A MAIN program in which variables are initialized, the user is given the opportunity to change default program values, and the input is read. Calls to the various subroutines used to calculate the consequences of the accident scenarios are made from the MAIN program.

(2) SUBROUTINE DRAD performs the direct radiation calculations. Output from this subroutine includes the radiological dose received (mrem) due to direct exposure.

(3) SUBROUTINE DISPERSE performs the atmospheric dispersion calculations for stability classes A-G. Output from this subroutine includes the highest value of concentration $\left(\mathrm{mg} / \mathrm{m}^{3}\right)$ at a given downwind distance along with the stability class which results in this maximum concentration.

(4) SUBROUTINE INHAL determines the radiological and/or chemical consequences of inhalation due to the airborne release of hazardous material. Output from this subroutine includes the radiation dose $(\mathrm{mrem})$ and the uptake $(\mathrm{mg})$ received due to inhalation.

(5) SUBROUTINE WATER calculates the amount of contaminant which reaches the public drinking supply due to a spill into a waterway. Output from this subroutine includes the mass of contaminant (mg) present in an individual's daily water uptake.

(6) SUBROUTINE INGST determines the radiological and/or chemical consequences of ingestion resulting from a spill of material into a waterway. Output from this subroutine includes the radiation dose (mrem) and intake $(\mathrm{mg})$ received due to ingestion.

(7) DATABASE is the block data subprogram containing the pre-defined material data.

\subsection{PROGRAM DEFAULT VALUES}

Several variables which are given default values in the program can easily be changed by the user. The user is interactively given the opportunity to change any or all of the values shown in Table 2.1. The bases for selecting these default values are discussed in Chapters 4-6 as the variables are introduced in relation to the calculations.

\subsection{PROGRAM INPUT}

The FORTRAN program operates in an interactive mode. Upon program execution, the user will be prompted to enter the name of the output file. The extension. OUT will automatically be added to the file name. The default output file name is TSRA.OUT. Next, the user will be given the opportunity to change the default values presented in Table 2.1. At this point, any user-defined material data will be read 
Table 2.1. Program Default Values

\begin{tabular}{|c|c|}
\hline Variable & Value \\
\hline \multicolumn{2}{|c|}{ Direct Radiation Calculations } \\
\hline Distance from the source & $152.4 \mathrm{~m}(500 \mathrm{ft})$ \\
\hline Exposure time & $3 \mathrm{hr}$ \\
\hline \multicolumn{2}{|c|}{ Atmospheric Dispersion Calculations } \\
\hline Minimum downwind distance & $100 \mathrm{~m}$ \\
\hline Maximum downwind distance & $2000 \mathrm{~m}$ \\
\hline Downwind distance increment & $100 \mathrm{~m}$ \\
\hline Elevation of receptor & 0 \\
\hline Ambient temperature & $298 \mathrm{~K}$ \\
\hline Initial plume radius & $0.5 \mathrm{~m}$ \\
\hline Wind velocity at elevation of $2 \mathrm{~m}$ & $1 \mathrm{~m} / \mathrm{s}$ \\
\hline \multicolumn{2}{|c|}{ Inhalation Calculations } \\
\hline Breathing rate & $1.2 \mathrm{~m}^{3} / \mathrm{hr}$ \\
\hline Exposure time & Fire duration \\
\hline \multicolumn{2}{|c|}{ Water Transport Calculations } \\
\hline Volume of water $\operatorname{tank}$ & $473 \mathrm{~m}^{3}$ \\
\hline Individual's daily uptake of water & $0.002 \mathrm{~m}^{3}$ \\
\hline
\end{tabular}


from the file TSRA.DAT created by the user (see following discussion for file format). Next, the user will be presented with a list of available materials (see Chapter 3 for a complete list and discussion of the available materials). The user will be asked to choose the materials of interest for the bounding calculations. Next, the user will be asked to enter the total mass present of each material chosen. For standard program execution, this is the only input required. The screen output from two sample runs (one without and one with user-supplied materials) is presented in Appendix B which shows everything printed to the screen during execution of the program.

Currently, a total of 18 materials are defined in the material database (see Chapter 3 for a discussion of the materials included). For all of these pre-defined materials, properties required for the bounding release calculations are contained in data statements in the block data subprogram (see Appendix A). A total of 32 additional materials may be defined by the user, as required. If the user wishes to analyze a material that is not contained in the database, a file named TSRA.DAT must be created to contain the required material data. The remainder of this section describes the process of adding a material to the database. All user-defined entries in the database are free format. All entries in each card should be separated by either a comma or a space. Character variables, such as Material Name and Isotope Name, should be enclosed in single quotes if the string contains any embedded spaces (i.e., 'Depleted Uranium'). The single quote character is obtained in WordPerfect by using character $(0,39)$ from the ASCII character set. If the character string contains no spaces (i.e., Th-232), single quotes are not required. Each user-defined material entry has the following format:

\section{CARD 1}

\section{Material ID, Material Name, Number of Isotopes}

The Material ID is simply an integer (19-50) which identifies the material. Material IDs 1-18 are used for the materials already in the database; therefore, any new materials being added should have a Material ID of 19 or greater. Material IDs should be numbered consecutively without skipping any integer values.

The Material Name is a character string of up to 30 characters which identifies the material (i.e., Lithium Hydride, Uranium, etc.).

Number of Isotopes is an integer (0-10) that indicates the number of radionuclides of the particular element to be considered in the radiation calculations. For example, Natural Uranium has three radionuclides (U-234, U-235, U-238) which are considered in the radiation calculations. Therefore, an entry of 3 is entered for Number of Isotopes for Natural Uranium. If the material does not pose a radiological hazard, a value of 0 should be entered for this variable.

\section{CARD 2}

Molecular Weight of Plume, Burn Rate of Material, Flame Temperature

Molecular Weight of Plume is the initial molecular weight of the plume in $\mathrm{kg} / \mathrm{kmole}(\mathrm{lbm} / \mathrm{lbmole})$.

Burn Rate of Material is the rate at which the material burns in $\% / \mathrm{s}$.

Flame Temperature is the fire temperature in degrees Kelvin .

If Number of Isotopes is given a value of 0 (no radiological hazard) in Card 1. Cards 3-8 should be omitted. 
CARD 3

Isotope Name, Mass Fraction of Isotope

Isotope Name is a character string of up to 6 characters which identifies the radionuclide (i.e., U-234, Th-232, etc.).

Mass Fraction of Isotope is the mass fraction of the isotope which is present in the material. It should be noted that the mass fractions of all isotopes of a material should sum to 1.0 . If this is not the case, the program will print a warning message.

\section{CARD 4}

Molecular Weight of Isotope, Half Life of Isotope, Density of Isotope, Inhalation Dose Factor, Ingestion Dose Factor

Molecular Weight of Isotope is the molecular weight in $\mathrm{kg} / \mathrm{kmole}$ (or $\mathrm{lbm} / \mathrm{lbmole}$ ) of the radionuclide.

Half Life of Isotope is the half life (in years) of the radionuclide.

Density of Isotope is the density in $\mathrm{g} / \mathrm{cm}^{3}$ of the radionuclide.

Representative values for the molecular weight, half life and density of various radionuclides may be found in the CRC Handbook of Chemistry and Physics.

Inhalation Dose Factor is the dose factor (e.g., 50-year C.E.D.E.) in rem/Ci for inhalation.

Ingestion Dose Factor is the dose factor (e.g., 50-year C.E.D.E) in rem/Ci for ingestion.

Values of the inhalation and ingestion dose factors for various radionuclides may be found in Internal Dose Conversion Factors for Calculation of Dose to the Public (DOE/EH-0071).

\section{CARD 5}

\section{Direct Radiation Flag, Direct Radiation Constant}

Direct Radiation Flag is given an integer value of either 1 or 2 . A value of 2 indicates that the source data for direct radiation calculations is given as a constant $\left(\sum R_{j} S_{i j}\right)$. A value of 1 indicates that the source data $\left(S_{i j}\right)$ are given individually and the program performs the summation.

Direct Radiation Constant is required if the Direct Radiation Flag above is given a value of 2. This constant is given by $\sum R_{j} S_{i j}$ and has units of $\mathrm{mrem} / \mathrm{hr}-\mathrm{cm}$. Although this entry is not used in the calculations if the Direct Radiation Flag has a value of 1 , it must still be given a value (a value of 0 is recommended).

Cards 6-8 should be omitted if the Direct Radiation Flag has a value of 2. 


\section{CARD 6}

$S_{1}, S_{2}, S_{3}, S_{4}, S_{5}, S_{6}$

$S_{1}-S_{6}$ are the source terms for the radionuclide in $\gamma / \mathrm{cm}^{3} / \mathrm{s}$. These values should be obtained from a computer code such as ORIGEN.'

\section{CARD 7}

$S_{7}, S_{8}, S_{9}, S_{10}, S_{11}, S_{12}$

$S_{7}-S_{12}$ are the source terms for the radionuclide in $\gamma / \mathrm{cm}^{3} / \mathrm{s}$. These values should be obtained from a computer code such as ORIGEN.'

\section{CARD 8}

$S_{13}, S_{14}, S_{15}, S_{16}, S_{17}, S_{18}$

$S_{13}-S_{18}$ are the source terms for the radionuclide in $\gamma / \mathrm{cm}^{3} / \mathrm{s}$. These values should be obtained from a computer code such as ORIGEN. ${ }^{1}$

Cards 3-8 should be repeated for each radionuclide. In other words, there should be $\mathrm{n}$ sets of Cards 3-8 where $\mathrm{n}$ is the number of isotopes entered in Card 1.

An end of file card is required to indicate the termination of material data. This card should have the following format:

\section{0,'END OF FILE', 0}

A sample input file (TSRA.DAT) containing user-defined materials is presented in Appendix B.

\subsection{PROGRAM OUTPUT}

For each material chosen, the following output is provided:

(1) Radiological dose in rem received from direct exposure,

(2) Maximum downwind concentration in $\mathrm{mg} / \mathrm{m}^{3}$ and the product of concentration and exposure time in $\mathrm{mg}-\mathrm{hr} / \mathrm{m}^{3}$,

(3) Maximum radiological dose in rem received from inhalation,

(4) Maximum uptake in $\mathrm{mg}$ due to inhalation,

(5) Radiological dose in rem received from ingestion,

(6) Intake in $\mathrm{mg}$ due to ingestion.

An extensive listing of program output is provided in the file TSRA.OUT. In addition to the final output listed above, values of intermediate calculated variables as well as the input values used in the calculations are given in this output file for each material analyzed. All user-defined material data is also echoed to the output file. Sample output files are presented in Appendix B for cases with and without user-supplied materials. 



\section{MATERIALS CONSIDERED IN MODEL}

Table 3.1 contains the materials used in weapons packages that are included in the TSRA Bounding Release Model database. The list of materials selected for inclusion in the model was based on consideration of typical materials associated with weapons components and consultation with DOE/AL Nuclear Explosives Safety Division. A comprehensive treatment of components in a fire is outside the scope of this evaluation.

Since magnesium, polyethylene, polyethylpentene, silicone, tungsten and urethane are assumed to be standard industrial hazards, no consequence calculations will be performed for these materials, although they are included in the model database. The only materials which pose a radiological hazard are thorium, uranium and the alloys containing uranium. The isotopes of these elements considered in the radiation dose calculations are also shown in Table 3.1.

Isotopic compositions are needed for those materials which pose a radiological hazard. Table 3.2 contains the assumed radionuclide mass fractions for the radiological materials contained in the database. Thorium is assumed to consist of $100 \%$ Th-232. If compositions other than those shown in Table 3.2 are desired, a new material would need to be added to the database as described in Section 2.2. 
Table 3.1. Materials Included in the Database

\begin{tabular}{|c|c|}
\hline Material & $\begin{array}{l}\text { Radionuclides Considered in Radiation Dose } \\
\text { Calculations }\end{array}$ \\
\hline \multicolumn{2}{|l|}{ Beryllium } \\
\hline \multicolumn{2}{|l|}{ Beryllium Oxide [BeO] } \\
\hline \multicolumn{2}{|l|}{ Boron } \\
\hline \multicolumn{2}{|l|}{ Lithium Deuteride [LiD] } \\
\hline \multicolumn{2}{|l|}{ Lithium Hydride [LiH] } \\
\hline \multicolumn{2}{|l|}{ Magnesium } \\
\hline \multicolumn{2}{|l|}{ Polyethylene } \\
\hline \multicolumn{2}{|l|}{ Polyethylpentene } \\
\hline \multicolumn{2}{|l|}{ Silicone $\left[\mathrm{SiO}\left(\mathrm{CH}_{3}\right)_{2}\right]$} \\
\hline \multicolumn{2}{|l|}{ Tantalum } \\
\hline Thorium & Th-232 \\
\hline \multicolumn{2}{|l|}{ Tungsten } \\
\hline Highly Enriched Uranium & U-232, U-234, U-235, U-236, and U-238 \\
\hline Natural Uranium & U-234, U-235 and U-238 \\
\hline Depleted Uranium & $\mathrm{U}-235$ and U-238 \\
\hline Uranium-Niobium Alloy & $\mathrm{U}-235$ and $\mathrm{U}-238$ \\
\hline Uranium-Niobium-Zirconium Alloy & $\mathrm{U}-235$ and $\mathrm{U}-238$ \\
\hline Urethane $\left[\mathrm{C}_{3} \mathrm{H}_{2} \mathrm{NO}_{2}\right]$ & \\
\hline
\end{tabular}


Table 3.2. Isotopic Compositions of Radiological Materials

\begin{tabular}{|c|c|c|c|c|c|}
\hline \multirow{2}{*}{ Compound } & \multicolumn{5}{|c|}{ Mass Fraction } \\
\hline & $\mathrm{U}-232$ & U-234 & $\mathrm{U}-235$ & U-236 & $\mathrm{U}-238$ \\
\hline Highly Enriched Uranium ${ }^{\mathrm{a}}$ & $4.0 \mathrm{E}-08$ & 0.012 & 0.94 & 0.0048 & 0.04319996 \\
\hline Natural Uranium ${ }^{b}$ & - & $5.6 \mathrm{E}-05$ & 0.00705 & - & 0.992894 \\
\hline Depleted Uranium $^{b}$ & - & - & 0.00195 & - & 0.99805 \\
\hline $\begin{array}{l}\text { Uranium -Niobium Alloy } \\
\text { [94.8\% U (Depleted), 5.2\% Nb] }\end{array}$ & - & - & 0.0018486 & - & 0.9461514 \\
\hline $\begin{array}{l}\text { Uranium-Niobium-Zirconium Alloy } \\
{[90 \% \mathrm{U} \text { (Depleted), } 7.5 \% \mathrm{Nb}, 2.5 \%} \\
\mathrm{Zr}]\end{array}$ & - & - & 0.001755 & - & 0.898245 \\
\hline
\end{tabular}

Sources: $\quad$ a. Internal memorandum to R. A. Just from J. F. DeClue and D. A. Tollefson, October $11,1995$.

b. Internal memorandum to R. A. Just from J. F. DeClue and D. A. Tollefson, October $20,1995$. 



\section{DIRECT RADIATION EXPOSURE}

If all of the material is conservatively assumed to be exposed and unshielded and all the radiation emanates from a single point source, the dose rate for a specific material may be calculated as

$$
D=\frac{1}{4 \pi r^{2}} \sum_{i=1}^{N} \sum_{j=1}^{18} \frac{m_{i}}{\rho_{i}} S_{i j} R_{j},
$$

where

$$
\begin{aligned}
D & =\text { dose rate }(\mathrm{mrem} / \mathrm{hr}) \\
r & =\text { distance from source }(\mathrm{cm}) \\
N & =\text { number of isotopes being considered, } \\
m_{i} & =\text { mass present of isotope } i(\mathrm{~g}) \\
\rho_{i} & =\text { density of isotope } i\left(\mathrm{~g} / \mathrm{cm}^{3}\right) \\
S_{i j} & =\text { source term for isotope } i \text { and group } j\left(\gamma / \mathrm{cm}^{3} / \mathrm{s}\right) \\
R_{j} & =\text { response term for group } j\left[(\mathrm{mrem} / \mathrm{hr}) /\left(\gamma / \mathrm{cm}^{2} / \mathrm{s}\right)\right]
\end{aligned}
$$

Guidance from DOE-AL indicates that in the event of an accident which does not involve high energy explosives, the security force will establish a perimeter of $500 \mathrm{ft}$ around the accident site. Therefore, the Maximally Exposed Individual is assumed to be located a minimum of $152.4 \mathrm{~m}(500 \mathrm{ft})$ from the postulated point source. This default value may be easily changed if direct dose calculations are desired at other distances (e.g., to evaluate the dose to security forces moving the SST contents). The radiological dose received in mrem is simply the product of the dose rate $(D)$ and the exposure time. In the event of a major accident, it might take several hours to restore the hazardous material to a proper environment. Although there is no definitive basis for predicting the exposure time, a value of 3 hours is assumed as the default.

The response terms $\left(R_{j}\right)$ needed in the direct radiation calculations are independent of the material or nuclide and are presented in Table 4.1. The densities of the radionuclides of interest in this study are presented in Table 4.2. The nuclide densities in Table 4.2 were calculated as the product of the density of the most abundant nuclide and the molecular weight ratio between the isotope of interest and the most abundant isotope. S. N. Cramer of the Radiation Shielding Information Center in the Computational Physics and Engineering Division used the ORIGEN computer code to predict the source terms $\left(S_{i j}\right)$ for the various isotopes.' B. L. Broadhead of the Nuclear Engineering Applications Section in the Computational Physics and Engineering Division performed an independent verification of Cramer's analyses. Results of both analyses as well as the assumed decay times are presented in Table 4.3. The decay times listed in Table 4.3 indicate the time at which the dose rate is a maximum. In general, Cramer and Broadhead's results are fairly consistent. Cramer's results were used in the FORTRAN code.

Bremsstrahlung, which is the electromagnetic radiation produced by a charged particle subjected to a change in velocity, was included in the direct dose calculations. Including the Bremsstrahlung should result in conservative results. The determination as to whether or not the Bremsstrahlung are included usually depends on the medium. For instance, if an oxide or water medium is assumed, the Bremsstrahlung should definitely be included. Usually the effect of neglecting the Bremsstrahlung on total dose rate is insignificant; however, for some isotopes such as U-238, it has a very significant effect (i.e., $32.06 \mathrm{mrem} / \mathrm{hr}-\mathrm{cm}$ without Bremsstrahlung and 134.9 with Bremsstrahlung). 
Table 4.1. Response Terms for All Nuclides

\begin{tabular}{|c|c|}
\hline$j$ & $R_{i}\left[(\mathrm{mrem} / \mathrm{hr}) /\left(\mathrm{\gamma} / \mathrm{cm}^{2} / \mathrm{s}\right)\right]$ \\
\hline 1 & $8.771 \mathrm{E}-03$ \\
\hline 2 & $7.478 \mathrm{E}-03$ \\
\hline 3 & $6.374 \mathrm{E}-03$ \\
\hline 4 & $5.413 \mathrm{E}-03$ \\
\hline 5 & $4.622 \mathrm{E}-03$ \\
\hline 6 & $3.959 \mathrm{E}-03$ \\
\hline 7 & $3.468 \mathrm{E}-03$ \\
\hline 8 & $3.019 \mathrm{E}-03$ \\
\hline 9 & $2.627 \mathrm{E}-03$ \\
\hline 10 & $2.205 \mathrm{E}-03$ \\
\hline 11 & $1.832 \mathrm{E}-03$ \\
\hline 12 & $1.522 \mathrm{E}-03$ \\
\hline 13 & $1.172 \mathrm{E}-03$ \\
\hline 14 & $8.759 \mathrm{E}-04$ \\
\hline 15 & $6.306 \mathrm{E}-04$ \\
\hline 16 & $3.833 \mathrm{E}-04$ \\
\hline 17 & $2.669 \mathrm{E}-04$ \\
\hline 18 & $9.347 \mathrm{E}-04$ \\
\hline
\end{tabular}

Source: ANSI/ANS-6.1.1-1977, Neutron and Gamma-Ray Flux-to-Dose-Rate Factors, American Nuclear Society, 1977. 
Table 4.2. Properties of the Nuclides

\begin{tabular}{|c|c|c|c|}
\hline Nuclide & Molecular Weight & $\begin{array}{l}\text { Half Life } \\
\text { (years) }\end{array}$ & $\begin{array}{l}\text { Density } \\
\left(\mathrm{g} / \mathrm{cm}^{3}\right) \\
\end{array}$ \\
\hline Th-232 & 232.038054 & $1.4 \mathrm{E} 10$ & 11.7 \\
\hline U-232 & 232.03713 & 68.9 & 18.57 \\
\hline U-234 & 234.040946 & $2.450 \mathrm{E} 05$ & 18.72 \\
\hline U-235 & 235.043924 & $7.04 \mathrm{E} 08$ & 18.81 \\
\hline U-236 & 236.045562 & $2.34 \mathrm{E} 07$ & 18.89 \\
\hline U-238 & 238.050784 & $4.46 \mathrm{E} 09$ & 19.05 \\
\hline
\end{tabular}

Sources: $\quad$ a. $\quad$ CRC Handbook of Chemistry and Physics, 73rd ed., CRC Press, Inc., 1993.

b. Uranium radionuclide densities calculated as the product of the density of the most abundant nuclide (U-238) and the molecular weight ratio between the isotope of interest and U-238. 
Table 4.3. Source Terms for the Nuclides

\begin{tabular}{|c|c|c|c|c|c|}
\hline \multirow[t]{2}{*}{ Nuclide } & \multicolumn{3}{|c|}{$\sum S_{i} R_{j}($ mrem/hr-cm) } & \multicolumn{2}{|c|}{$\begin{array}{l}\text { Decay Time for Maximur } \\
\text { Dose }(y)\end{array}$} \\
\hline & Cramer & Broadhead & Percent Difference & Cramer & Broadhead \\
\hline Th-232 & $2.628 \mathrm{E} 02^{*}$ & $2.620 \mathrm{E} 02$ & 0.30 & 100 & 100 \\
\hline $\mathrm{U}-232$ & 4.342E $10^{*}$ & $4.438 \mathrm{E} 10$ & 2.15 & 10 & 10 \\
\hline $\mathrm{U}-234$ & $1.841 \mathrm{E} 05^{*}$ & $1.831 \mathrm{E} 05$ & 0.53 & 100 & 10 \\
\hline U-235 & $1.131 \mathrm{E} 03^{*}$ & $1.122 \mathrm{E} 03$ & 0.73 & 100 & 10 \\
\hline U-236 & $2.478 \mathrm{E} 00^{*}$ & $2.557 \mathrm{E} 00$ & 3.11 & 10 & 10 \\
\hline $\mathrm{U}-238$ & $1.349 \mathrm{E} 02^{*}$ & $1.346 \mathrm{E} 02$ & 0.28 & 10 & 10 \\
\hline
\end{tabular}

- Note Dose rates based on gammas only [dose rates from neutrons are several orders of magnitude (2-6) smaller than dose rates from gammas]. 


\section{AIRBORNE RELEASES}

One of the accident scenarios which must be considered involves the airborne release of material resulting from a fire. Both the radiological and chemical hazards due to inhalation to an individual downwind of the fire must be calculated.

\subsection{RELEASE RATES}

Information or data regarding oxidation or burning rates of metals and other materials considered in this analysis is scarce. In the absence of a better model, the release factor value of $8.9 \times 10^{-3} \% / \mathrm{s}$ recommended by R. A. Just is used for all the metals. ${ }^{7}$ This value is based on data presented in the Nuclear Fuel Cycle Facility Accident Analysis Handbook ${ }^{2}$ and information provided in J. M. Napier's Release of Uranium to Air During Oxidation of Uranium Chips ${ }^{3}$. It should be noted that this value results in burn durations of $3.12 \mathrm{hr}$ regardless of the initial mass of the material present. Although unrealistic, this release rate represents an average rate throughout the process and should lead to reasonable results for relatively small quantities of metal. Although this model is very crude, it is believed to be conservative since test data for pyrophoric metals indicate significantly longer burn times. Experimental data were available for the combustion of lithium hydride. ${ }^{4}$ In order to be consistent with the other values, this data was converted into units of $\% / s$. It is assumed that the release rate for lithium deuteride is equal to that of lithium hydride.

The release rates assumed for the analyses are presented in Table 5.1. Since it is assumed that beryllium oxide will not oxidize further, no burning rate is presented in Table 5.1 for this material. Available information and comments regarding the flammability of the materials considered in this analysis are also presented in Table 5.1

These analyses conservatively assume that $100 \%$ of the burned material becomes airborne. This assumption insures conservative results given the inherent uncertanties in dispersion analysis and to account for the possibility that a receptor may be at an elevated location. If this assumption results in unfavorable consequences, the analysis should be refined by choosing a more realistic value for the the airborne release fraction.

\subsection{ATMOSPHERIC DISPERSION}

The concentration may be evaluated using the standard Gaussian dispersion equation. ${ }^{5}$ The concentration at coordinates $X, Y, Z$ is

$$
\dot{C}=\left(\frac{Q}{2 \pi \sigma_{y} \sigma_{z} U}\right) \exp \left(\frac{-Y^{2}}{2 \sigma_{y}^{2}}\right)\left[\exp \left(\frac{-(Z-h)^{2}}{2 \sigma_{z}^{2}}\right)+\exp \left(\frac{-(Z+h)^{2}}{2 \sigma_{z}^{2}}\right)\right]
$$

where

$$
\begin{aligned}
& C=\text { concentration }\left(\mathrm{mg} / \mathrm{m}^{3}\right) \\
& Q=\text { release rate }(\mathrm{mg} / \mathrm{s}) \\
& \sigma_{y}=\text { crosswind dispersion coefficient }(\mathrm{m}), \\
& \sigma_{z}=\text { vertical dispersion coefficient }(\mathrm{m}),
\end{aligned}
$$


Table 5.1 Burning Rates of Materials

\begin{tabular}{||l|l|c||}
\hline \multicolumn{1}{|c|}{ Material } & \multicolumn{1}{|c|}{ Notes Regarding Flammability } & Burn Rate $(\% / \mathrm{s})$ \\
\hline Beryllium & $\begin{array}{l}\text { Moderate fire hazard in dust or powder } \\
\text { form }^{\mathrm{a}}\end{array}$ & $8.9 \mathrm{E}-03$ \\
\hline Beryllium Oxide & Not expected to oxidize further $^{-03}$ & \\
\hline Boron & Flammable in dust form & \\
\hline Lithium Deuteride & Highly flammable & $8.9 \mathrm{E}-03$ \\
\hline Lithium Hydride & Highly flammable & $6.846 \mathrm{E}-01$ \\
\hline Tantalum & Dry powder ignites spontaneously in air & $6.846 \mathrm{E}-01$ \\
\hline Thorium & Powder may ignite spontaneously in air ${ }^{\mathrm{a}}$ & $8.9 \mathrm{E}-03$ \\
\hline Uranium & $\begin{array}{l}\text { Flammable in the solid or dust form when } \\
\text { exposed to heat or flame }\end{array}$ & $8.9 \mathrm{E}-03$ \\
\hline Uranium-Niobium Alloy & Niobium is flammable in dust form & $8.9 \mathrm{E}-03$ \\
\hline $\begin{array}{l}\text { aranium-Niobium-Zirconium } \\
\text { Alloy }\end{array}$ & $\begin{array}{l}\text { Zirconium is very dangerous fire hazard } \\
\text { in dust form }^{\mathrm{a}}\end{array}$ & $8.9 \mathrm{E}-03$ \\
\hline
\end{tabular}

Sources: $\quad$ a. $\quad$ Lewis, R. J. Sr., Sax's Dangerous Properties of Industrial Materials (Vol. I-III), Eighth edition, Van Nostrand Reinhold, N.Y., 1992. 


$$
\begin{aligned}
U & =\text { average ambient wind velocity between elevations } 0 \text { and } \mathrm{h}(\mathrm{m} / \mathrm{s}), \\
Y & =\text { crosswind distance }(\mathrm{m}), \\
Z & =\text { elevation }(\mathrm{m}), \\
h & =\text { plume height }(\mathrm{m}) .
\end{aligned}
$$

Centerline, ground level air concentrations are predicted by assuming $Y=0$ and $Z=0$. The release rate is assumed to be equal to the burning rate of the material (see Table 5.1). The crosswind dispersion coefficient is calculated as ${ }^{6}$

$$
\sigma_{y}=y_{1} X(1.0+0.0001 X)^{-1 / 2} \text {, }
$$

where $\quad X=$ downwind distance $(\mathrm{m})$.

The values of the constant $y_{1}$ are given in Table 5.2 for stability classes A-G. The vertical dispersion coefficient is calculated $a^{6}$

$$
\sigma_{z}=z_{1} X\left(z_{2}+z_{3} X\right)^{z_{4}}
$$

The values of the constants $z_{1}-z_{4}$ are given in Table 5.2 for stability classes A-G. Equations 5.2 and 5.3 are valid for $100 \leq X \leq 10,000 \mathrm{~m}$.

The equilibrium or maximum plume rise $\left(h_{\max }\right)$ may be estimated by ${ }^{7}$

$$
h_{\max }=2.6^{\frac{3}{3+p}}\left[\frac{g(p+1)\left(1-\frac{T_{a} M_{o}}{T_{o} M_{a}}\right) w_{o} r_{o}^{2}}{\frac{u_{2} s}{2^{p}}}\right]^{\frac{1}{3+p}},
$$

where

$$
\begin{aligned}
p & =\text { constant, } \\
g & =\text { acceleration due to gravity }\left(\mathrm{m} / \mathrm{s}^{2}\right), \\
T_{a} & =\text { ambient temperature }(\mathrm{K}), \\
M_{o} & =\text { initial molecular weight of the plume, } \\
T_{o} & =\text { flame temperature }(\mathrm{K}), \\
M_{a} & =\text { molecular weight of ambient air, } \\
w_{0} & =\text { initial vertical velocity of the plume }(\mathrm{m} / \mathrm{s}), \\
r_{o} & =\text { initial plume radius }(\mathrm{m}), \\
u_{2} & =\text { wind velocity at an elevation of } 2 \mathrm{~m}(\mathrm{~m} / \mathrm{s}), \\
s & =\text { stability parameter }\left(\mathrm{s}^{-2}\right) .
\end{aligned}
$$

Values of $298 \mathrm{~K}\left(77^{\circ} \mathrm{F}\right)$ and $28.964 \mathrm{~kg} / \mathrm{kmole}$ may be assumed for the ambient temperature and molecular weight of ambient air, respectively. The ambient temperature has an effect on the plume rise and the initial plume temperature. As the ambient temperature increases, the plume rise and the initial plume temperature 
increase. However, the effects of varying the ambient temperature from -25 to $50^{\circ} \mathrm{C}$ on the plume rise and Table 5.2. Dispersion Coefficient Constants

\begin{tabular}{|c|c|c|c|c|c|}
\hline Stability Class & $y_{1}$ & $z_{2}$ & $z_{2}$ & $z_{3}$ & $z_{3}$ \\
\hline \hline $\mathrm{A}^{\mathrm{a}}$ & 0.22 & 0.2 & 1 & 0 & 0 \\
\hline $\mathrm{B}^{\mathrm{a}}$ & 0.16 & 0.12 & 1 & 0 & 0 \\
\hline $\mathrm{C}^{\mathrm{a}}$ & 0.11 & 0.08 & 1 & 0.0002 & -0.5 \\
\hline $\mathrm{D}^{\mathrm{a}}$ & 0.08 & 0.06 & 1 & 0.0015 & -0.5 \\
\hline $\mathrm{E}^{\mathrm{a}}$ & 0.06 & 0.03 & 1 & 0.0003 & -1 \\
\hline $\mathrm{F}^{\mathrm{a}}$ & 0.04 & 0.016 & 1 & 0.0003 & -1 \\
\hline $\mathrm{G}^{\mathrm{b}}$ & $0.67(0.04)=0.0268$ & $0.6(0.016)=0.0096$ & 1 & 0.0003 & -1 \\
\hline
\end{tabular}

Sources: $\quad$ a. $\quad$ Hanna, S. R., Briggs, G. A. And Hosker, R. P. Jr., Handbook on Atmospheric Diffusion, DOE/TIC-11223, U. S. Department of Energy, Office of Energy Research, Washington, D. C., 1982.

b. U. S. Nuclear Regulatory Commission, On-Site Meteorological Programs, Regulatory Guide 1.23, 1972. 
initial plume temperature are estimated to be less than $6 \%{ }^{7}$ Values of the constant $(p)$ and stability parameter $(s)$ are given in Table 5.3 for stability classes A-G. Since a value of $p$ is not defined for G stability, the analysis will use the value of 0.55 associated with $F$ stability. Details regarding the determination of the stability parameter are provided in R. A. Just's report. ${ }^{7}$ Hydrocarbon pool fires typically have initial upward velocities ranging from 1 to $4 \mathrm{~m} / \mathrm{s}^{8}$ Since lower initial vertical plume velocities result in lower plume rise and subsequently higher downwind concentrations, it is conservative to assume a value of $1 \mathrm{~m} / \mathrm{s}$ for the initial plume velocity. Since a significant fire would more than likely be at least $1 \mathrm{~m}$ in diameter, an initial plume radius of $0.5 \mathrm{~m}$ is assumed to be reasonable. Since this analysis is intended for an arbitrary location, site specific wind velocity data is unobtainable. For most situations, ground level concentrations increase with decreasing wind velocities. Since the Gaussian dispersion coefficients are valid for wind velocities of $1 \mathrm{~m} / \mathrm{s}$ or greater, a wind velocity of $1 \mathrm{~m} / \mathrm{s}$ should provide conservative results.

The plume height at any downwind distance may be calculated by ${ }^{7}$

$$
h=\left[\frac{\left.1.6(p+1)\left[g\left(1-\frac{T_{a} M_{o}}{T_{o} M_{a}}\right) w_{o} r_{o}^{2}\right]^{1 / 3}\right]^{\frac{1}{1+p}}}{\frac{u_{2}}{2^{p}}} X^{\frac{2}{3+3 p}}\right.
$$

Since the plume height predicted by Eq. 5.5 should not exceed the maximum plume rise predicted by Eq. 5.4 , the smaller of these two values should be used as the plume height in the calculation of the downwind concentration (Eq. 5.1).

The general form of the vertical velocity profile is given in Reference 9. The following form is written specifically for an elevation of 2 meters:

$$
u=u_{2}\left(\frac{h}{2}\right)^{p}
$$

The average ambient wind velocity may be obtained by integrating Eq. 5.6 from $h=0$ to $h=h_{\max }$. This yields

$$
U=\frac{\left[u_{2}\left(\frac{h_{\max }}{2}\right)^{p}\right]}{p+1} .
$$


Table 5.3. Constants Required for Plume Rise Calculations

\begin{tabular}{|c|c|c||}
\hline \hline Stability Class & (Rural terrain) & 0.0 \\
\hline A & $0.07^{\mathrm{a}}$ & $1.6 \mathrm{E}-04^{\mathrm{b}}$ \\
\hline $\mathrm{B}$ & $0.07^{\mathrm{a}}$ & $1.6 \mathrm{E}-04^{\mathrm{b}}$ \\
\hline $\mathrm{C}$ & $0.1^{\mathrm{a}}$ & $1.6 \mathrm{E}-04^{\mathrm{b}}$ \\
\hline $\mathrm{D}$ & $0.15^{\mathrm{a}}$ & $1.6 \mathrm{E}-04^{\mathrm{b}}$ \\
\hline $\mathrm{E}$ & $0.35^{\mathrm{a}}$ & $8.2 \mathrm{E}-04^{\mathrm{b}}$ \\
\hline $\mathrm{F}$ & $0.55^{\mathrm{a}}$ & $1.6 \mathrm{E}-03^{\mathrm{b}}$ \\
\hline $\mathrm{G}$ & $0.55^{\mathrm{b}}$ & $1.6 \mathrm{E}-03^{\mathrm{b}}$ \\
\hline
\end{tabular}

Sources: a. Hanna, S. R., Briggs, G. A. And Hosker, R. P. Jr., Handbook on Atmospheric Diffusion, DOE/TIC-1 1223, U. S. Department of Energy, Office of Energy Research, Washington, D. C., 1982.

b. Just, R. A., Support for Nuclear Explosive Safety Division, Department of Energy, Albuquerque Operations - Effects of a Postulated Uranium Transportation Accident, Y/LF-504, January 1996.

\subsection{RADIOLOGICAL CONSEQUENCES OF INHALATION}

The radiological exposure received due to inhalation resulting from the fire may be calculated as

$$
D_{\text {fire }}=\frac{(C)\left[\sum_{i=1}^{N}\left(A_{i}\right)\left(D F_{\text {inhale, } i}\right)\left(F_{i}\right)\right](b)(t)}{1 \times 10^{3}}
$$

where $\quad D_{\text {fire }}=$ radiological dose received from inhalation (rem),

$C=$ downwind concentration $\left(\mathrm{mg} / \mathrm{m}^{3}\right)$,

$N=$ number of isotopes considered for the material,

$A_{i}=$ activity of isotope $i(\mathrm{Ci} / \mathrm{g})$,

$D F_{\text {inhale }, i}=$ inhalation dose conversion factor for isotope $i(\mathrm{rem} / \mathrm{Ci})$,

$F_{i}=$ mass fraction of isotope $i$,

$b=$ breathing rate $\left(\mathrm{m}^{3} / \mathrm{hr}\right)$,

$t=$ exposure time (hr).

Equation 5.8 gives the radiological dose received due to the burning of a single material containing $N$ isotopes. If the postulated fire involves several materials, the doses for each material should be calculated by Eq. 5.8 and then summed to obtain the total radiation dose received. 
The activity is calculated as ${ }^{9}$

$$
A_{i}=\frac{3.578 \times 10^{5}}{\left(M W_{i}\right)\left(\tau_{i}\right)},
$$

where $\quad M W_{i}=$ molecular weight of isotope $i$,

$\tau_{i}=$ half life of isotope $i$ (years).

The inhalation dose conversion factors for the radionuclides of interest in this study are presented in Table 5.4. The values in Table 5.4 represent 50 -year committed effective dose equivalents (C.E.D.E.). A typical value of breathing rate is approximately $1.2 \mathrm{~m}^{3} / \mathrm{hr}$. As a default, the exposure time is assumed to be equal to the duration of the fire, which is calculated as

$$
t=\frac{m}{3600 Q}
$$

where

$$
\begin{aligned}
t & =\text { exposure time }(\mathrm{hr}) \\
m & =\text { initial mass of material }(\mathrm{mg}) \\
Q & =\text { release rate }(\mathrm{mg} / \mathrm{s})
\end{aligned}
$$

\subsection{CHEMICAL CONSEQUENCES OF INHALATION}

The uptake in mg due to inhalation is calculated as

$$
\text { Uptake }=(C)(b)(t) .
$$


Table 5.4. Dose Conversion Factors

\begin{tabular}{|c|c|c||}
\hline Nuclide $^{*}$ & $\begin{array}{c}\text { Inhalation Dose Conversion } \\
\text { Factor (rem/Ci) }\end{array}$ & $\begin{array}{c}\text { Ingestion Dose Conversion } \\
\text { Factor (rem/Ci) }\end{array}$ \\
\hline Th-232 & $1.6 \mathrm{E} 09$ & $2.8 \mathrm{E} 06$ \\
\hline $\mathrm{U}-232$ & $6.7 \mathrm{E} 08$ & $1.3 \mathrm{E} 06$ \\
\hline $\mathrm{U}-234$ & $1.3 \mathrm{E} 08$ & $2.6 \mathrm{E} 05$ \\
\hline $\mathrm{U}-235$ & $1.2 \mathrm{E} 08$ & $2.5 \mathrm{E} 05$ \\
\hline $\mathrm{U}-236$ & $1.2 \mathrm{E} 08$ & $2.5 \mathrm{E} 05$ \\
\hline $\mathrm{U}-238$ & $1.2 \mathrm{E} 08$ & $2.3 \mathrm{E} 05$ \\
\hline
\end{tabular}

Source: Internal Dose Conversion Factors for Calculation of Dose to the Public, DOE/EH-0071, U.S. Department of Energy, Washington, D.C., July 1988. 


\section{WATER TRANSPORT SCENARIO}

Another accident scenario which must be considered involves a transportation accident which results in loss of containment and release of the hazardous material into a waterway. Subsequently, the material is assumed to be transported downstream, taken into a municipal water supply, and ingested by the public through drinking water. One possible mechanism for such a release would be runoff from a fire where water is applied to the burning material. Direct ingestion from a waterway is not considered due to low probability of a person drinking water directly downstream of a major highway following a transportation accident.

The amount of contaminant which is available to be ingested by an individual is calculated as

$$
m_{\text {cont }}=\frac{(m)(f)\left(V_{\text {drimk }}\right)}{V_{\text {tank }}}
$$

where $\quad m_{\text {cont }}=$ amount of contaminant ingested $(\mathrm{kg})$,

$m=$ initial mass of material released $(\mathrm{kg})$,

$f=$ fraction of contaminant which reaches public drinking supply,

$V_{\text {drink }}=$ individual daily uptake of water $\left(\mathrm{m}^{3}\right)$,

$V_{\text {tank }}=$ volume of water $\operatorname{tank}\left(\mathrm{m}^{3}\right)$.

A significant fraction of the small particles generated by the fire would likely become airborne. Those particles that remain on the ground and are available to be washed into the waterway would tend to be significantly larger than those that become airborne. In addition, fire fighting actions would probably extinguish the fire before combustion of the material is complete. Therefore, only a portion of the initial material would be expected to wash into the waterway. However, this analysis assumes that $100 \%$ of the material is released in a dispersable form to the waterway, either directly or due to runoff from a fire extinguishing stream.

Once the material reaches the waterway, advection and convection phenomena dilute the contaminated water and soil and sediment interaction will remove some of the contaminant from the waterway. Furthermore, the municipal water supply system will remove a significant portion of the contaminant through filtration and settling prior to public distribution. Information received from the Knoxville Utilities Board and ETMC/Johnson Controls (see Appendix C) indicates that only 0.29-0.6\% of the particles (in the 2-15 micron size range) at the water intake will pass through the filtration system. These data also indicate that no particles greater than 15 micron pass though the filtration system. If the material reaches a municipal water supply and is detected at an unacceptably high level, actions would be taken to prevent people from drinking the contaminated water. The Clean Water Act specifies disinfectant contact values for public water supplies. Required contact time is based on these values and determined by water temperature, $\mathrm{Ph}$, and disinfectant values. Since no notification is assumed, the material reaching the public is dependent on the effectiveness of the municipal system.

Although 500,000 to 2,000,000 gallon tanks are typical for main water systems, managers at local water treatment facilities indicated that 125,000 to 250,000 gallon tanks were also in use. Therefore, a minimum tank size of 125,000 gallons is assumed in the analysis. The analysis also assumes that an individual drinks an entire days supply of water (estimated to be two liters) from the contaminated source. Public ingestion through drinking is the only exposure pathway considered in the model; absorption through bodily contact and ingestion due to contaminated food are neglected. 
Taking into account these dilution and depletion mechanisms, the analysis conservatively assumes that $0.01(1 \%)$ of the initial quantity of hazardous material initially released passes through the municipal water system and is available for public ingestion. Neglecting emergency response actions, assuming a minimum tank size, and assuming an individual drinks an entire days supply of water from the contaminated source adds additional conservatism. It should be noted that the value of 0.01 is valid only for insoluble materials. Since lithium deuteride and lithium hydride are assumed to be completely water soluble, the analysis assumes that $100 \%$ of the initial material is available for public ingestion for these two compounds.

\subsection{RADIOLOGICAL CONSEQUENCES OF INGESTION}

The radiological dose received by an individual resulting from a spill into a waterway and subsequent uptake of the contaminated water may be calculated as

$$
D_{\text {spill }}=m_{\text {cont }}\left[\sum_{i=1}^{N}\left(A_{i}\right)\left(D F_{\text {ingest, } i}\right)\left(F_{i}\right)\right]\left(1 \times 10^{3}\right),
$$

where

$$
\begin{aligned}
D_{\text {spill }} & =\text { radiological dose received from ingestion (rem) } \\
N & =\text { number of isotopes considered for the material, } \\
A_{i} & =\text { activity of isotope } i(\mathrm{Ci} / \mathrm{g}) \\
D F_{\text {ingest }, i} & =\text { ingestion dose conversion factor for isotope } i(\mathrm{rem} / \mathrm{Ci}), \\
F_{i} & =\text { mass fraction of isotope } i
\end{aligned}
$$

Equation 6.2 gives the radiological dose received due to the ingestion of a single material containing $N$ isotopes. If the postulated release involves several materials, the doses for each material should be calculated by Eq. 6.2 and then summed to obtain the total radiation dose received. The activity is calculated as ${ }^{9}$

$$
A_{i}=\frac{3.578 \times 10^{5}}{\left(M W_{i}\right)\left(\tau_{i}\right)}
$$

where $\quad M W_{i}=$ molecular weight of isotope $i$,

$\tau_{i}=$ half life of isotope $i$ (years).

The ingestion dose conversion factors for the radionuclides of interest in this study are presented in Table 5.4. The values in Table 5.4 represent 50 -year committed effective dose equivalents (C.E.D.E.).

\subsection{CHEMICAL CONSEQUENCES OF INGESTION}

The intake in $\mathrm{mg}$ due to a spill into a waterway is

$$
\text { Intake }=\left(1 \times 10^{6}\right) m_{\text {cont }} .
$$




\section{SAMPLE RUNS AND RESULTS}

Sample runs were performed by arbitrarily assuming that $10 \mathrm{~kg}$ of each material was exposed for each of the accident scenarios (direct exposure, fire and spill into waterway). Since magnesium, polyethylene, polyethylpentene, silicone, tungsten and urethane are assumed to be standard industrial hazards, they were not analyzed. Since it is assumed that beryllium oxide will not oxidize further, calculations for this compound were not performed for the fire accident. The results of the sample runs are presented in Table 7.1. The initial molecular weight of the plume and the flame temperature were assumed to have values of 28.964 (molecular weight of air) and $1200 \mathrm{~K}$, respectively, for all the materials considered in the sample runs. Since an open flame is assumed, excess oxygen will probably be available for combustion. Therefore, an initial plume molecular weight equal to the molecular weight of air is assumed. Typical flame temperatures of hydrocarbon pool fires range from approximately 1200 to $1400 \mathrm{~K} .{ }^{10}$ Assuming a flame temperature of 1200 $\mathrm{K}$ should lead to conservative values of plume rise and, subsequently, concentration.

As mentioned in Chapter 3, the only materials which pose a radiological hazard are thorium, uranium and the alloys containing uranium. As evident from the results presented in Table 7.1, of the materials considered, Highly Enriched Uranium presents the worst radiological hazard. As seen from Table 7.1, the values of uptake due to inhalation resulting from a fire predicted by the model were identical regardless of the material. This implies that the uptake is independent of the burn rate. The explanation for this is related to the way in which the default exposure time is calculated by the model. As explained in Section 5.3, as the default, the exposure time is assumed to be equal to the fire duration which is inversely proportional to the burn rate (Eq. 5.10). Since the concentration is directly proportional to the burn rate (Eq. 5.1), the uptake, which is the product of the concentration, exposure time and breathing rate, is independent of the burn rate. Although the default values for exposure time were used for these sample runs, the exposure time for the fire accident is included as a user input so that values less than the fire duration may be used if desired. Using the fire duration for the exposure time will, however, result in the worst case scenario.

The intake due to ingestion resulting from a spill into a waterway is also the same for all the materials considered in this study with the exception of lithium hydride and lithium deuteride. This occurs since the fraction of material which reaches the public drinking system is assumed to be the same (0.01) for all the materials except the lithium compounds. In reality, this value is probably a function of the material solubility, size of the particles, etc. 
Table 7.1. Model Results

\begin{tabular}{|c|c|c|c|c|c|c|c|}
\hline \multirow{2}{*}{ Material } & \multirow{2}{*}{$\begin{array}{l}\text { Direct Exposure } \\
\text { Direct Radiation } \\
\text { Dose } \\
\text { (rem) } \\
\end{array}$} & \multicolumn{4}{|c|}{$\begin{array}{l}\text { Fire Accident } \\
\text { (Inhalation) }\end{array}$} & \multicolumn{2}{|c|}{$\begin{array}{l}\text { Spill into Waterway } \\
\text { (Ingestion) }\end{array}$} \\
\hline & & $\begin{array}{l}\text { Concentration } \\
\\
\left(\mathrm{mg} / \mathrm{m}^{3}\right) \\
\end{array}$ & $\begin{array}{l}\text { Concentration } \\
\text { *Exposure Time } \\
\left(\mathrm{mg}-\mathrm{hr} / \mathrm{m}^{3}\right)\end{array}$ & $\begin{array}{c}\text { Radiation } \\
\text { Dose } \\
\text { (rem) } \\
\end{array}$ & $\begin{array}{l}\text { Uptake } \\
\text { (mg) }\end{array}$ & $\begin{array}{c}\text { Radiation } \\
\text { Dose } \\
(\mathrm{rem})\end{array}$ & $\begin{array}{l}\text { Intake } \\
\text { (ng) }\end{array}$ \\
\hline Beryllium & 0 & $1.0325 \mathrm{E}-01$ & $3.2224 \mathrm{E}-01$ & 0 & $3.8669 \mathrm{E}-01$ & 0 & $4.2268 \mathrm{E}-01$ \\
\hline Beryllium Oxide & 0 & not calculated & not calculated & 0 & not calculated & 0 & $4.2268 \mathrm{E}-01$ \\
\hline Boron & 0 & $1.0325 \mathrm{E}-01$ & $3.2224 \mathrm{E}-01$ & 0 & $3.8669 \mathrm{E}-01$ & 0 & $4.2268 \mathrm{E}-01$ \\
\hline Lithium Deuteride & 0 & 7.9418 & $3.2224 \mathrm{E}-01$ & 0 & $3.8669 \mathrm{E}-01$ & 0 & 42.268 \\
\hline Lithium Hydride & 0 & 7.9418 & $3.2224 \mathrm{E}-01$ & 0 & $3.8669 \mathrm{E}-01$ & 0 & 42.268 \\
\hline Tantalum & 0 & $1.0325 \mathrm{E}-01$ & $3.2224 \mathrm{E}-01$ & 0 & $3.8669 \mathrm{E}-01$ & 0 & $4.2268 \mathrm{E}-01$ \\
\hline Thorium & $2.3088 \mathrm{E}-07$ & $1.0325 \mathrm{E}-01$ & $3.2224 \mathrm{E}-01$ & $6.8145 \mathrm{E}-02$ & $3.8669 \mathrm{E}-01$ & $1.3035 \mathrm{E}-04$ & $4.2268 \mathrm{E}-01$ \\
\hline $\begin{array}{l}\text { Uranium } \\
\text { HighlyEnriched } \\
\text { Natural } \\
\text { Depleted }\end{array}$ & $\begin{array}{l}2.7582 \mathrm{E}-06 \\
8.2306 \mathrm{E}-08 \\
7.3871 \mathrm{E}-08\end{array}$ & $\begin{array}{l}1.0325 \mathrm{E}-01 \\
1.0325 \mathrm{E}-01 \\
1.0325 \mathrm{E}-01\end{array}$ & $\begin{array}{l}3.2224 \mathrm{E}-01 \\
3.2224 \mathrm{E}-01 \\
3.2224 \mathrm{E}-01\end{array}$ & $\begin{array}{c}4.1055 \\
3.3800 \mathrm{E}-02 \\
1.5803 \mathrm{E}-02\end{array}$ & $\begin{array}{l}3.8669 \mathrm{E}-01 \\
3.8669 \mathrm{E}-01 \\
3.8669 \mathrm{E}-01\end{array}$ & $\begin{array}{l}8.9699 \mathrm{E}-03 \\
7.2542 \mathrm{E}-05 \\
3.3144 \mathrm{E}-05\end{array}$ & $\begin{array}{l}4.2268 \mathrm{E}-01 \\
4.2268 \mathrm{E}-01 \\
4.2268 \mathrm{E}-01\end{array}$ \\
\hline $\begin{array}{l}\text { Uranium-Niobium } \\
\text { Alloy }\end{array}$ & $7.0029 \mathrm{E}-08$ & $1.0325 \mathrm{E}-01$ & $3.2224 \mathrm{E}-01$ & $1.4981 \mathrm{E}-02$ & $3.8669 \mathrm{E}-01$ & $3.1420 \mathrm{E}-05$ & 4.2268E-01 \\
\hline $\begin{array}{l}\text { Uranium-Niobium } \\
\text {-Zirconium Alloy }\end{array}$ & $6.6484 \mathrm{E}-08$ & $1.0325 \mathrm{E}-01$ & $3.2224 \mathrm{E}-01$ & $1.4223 \mathrm{E}-02$ & $3.8669 \mathrm{E}-01$ & $2.9829 \mathrm{E}-05$ & $4.2268 \mathrm{E}-01$ \\
\hline
\end{tabular}




\section{REFERENCES}

1. Hermann, O. W. And Westfall, R. M., “ORIGEN-S: SCALE System Module to Calculate Fuel Depletion, Actinide Transmutation, Fission Product Buildup and Decay, and Associated Radiation Source Terms", as described in Sect. F6 of SCALE: A Modular Code System for Performing Standardized Computer Analyses for Licensing Evaluation, Vols. 1-3, NUREG/CR-0200, U. S. Nuclear Regulatory Commission, Rev. 3, December 1984.

2. Ayer, J. E., et. al., Nuclear Fuel Cycle Facility Accident Analysis Handbook, NUREG-1320, U. S. Nuclear Regulatory Commission, May 1988.

3. Napier, J. M., Release of Uranium to Air During Oxidation of Uranium Chips, Internal Correspondence to I. Darling, Martin Marietta Energy Systems, Inc., Oak Ridge, TN, July 9, 1984.

4. Leckey, J. H. and Nulf, L. E., Lithium Hydride Combustion, Y/DZ-1044, April 1994.

5. Atmospheric Science and Power Production, DOE/TIC-27601 (DE84005177), U. S. Department of Energy, Office of Energy Research, Washington, D. C., 1984.

6. Hanna, S. R., Briggs, G. A. And Hosker, R. P. Jr., Handbook on Atmospheric Diffusion, DOE/TIC-1 1223, U. S. Department of Energy, Office of Energy Research, Washington, D. C., 1982.

7. Just, R. A., Support for Nuclear Explosive Safety Division, Department of Energy, Albuquerque Operations - Effects of a Postulated Uranium Transportation Accident, Y/LF-504, October 1997.

8. Zamejc, E. R. And Chao, C. C., Consequence Analysis of PCB-Containing Liquid Pool Fires, Battelle and Ontario Waste Management Corporation, Ontario, Canada, 1990.

9. Hazard Screening Application Guide, CSET-2, U. S. Department of Energy, Martin Marietta Energy Systems, Inc., Oak Ridge, TN, December 1990.

10. Professional Loss Control, Fire and Explosion Risk Assessment and Consequence Modeling Seminar, August 1994. 



\section{APPENDIX A}

FORTRAN Code Listing 


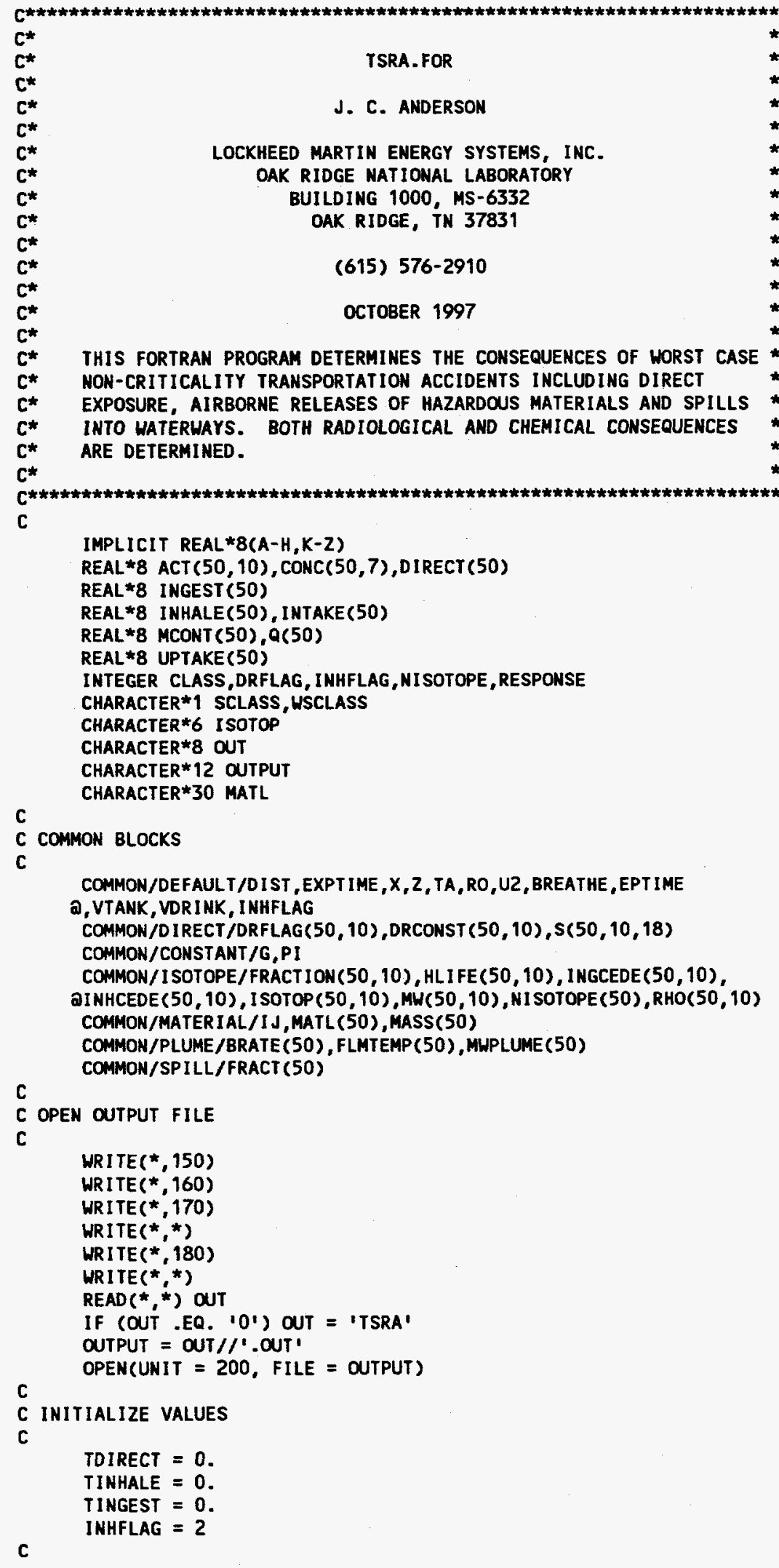


C SET DEFAULT VALUES

C

C ENTER THE DISTANCE FROM THE SOURCE FOR DIRECT RADIATION CALCULATIONS

$C(m)$

DIST $=152.4$

C ENTER THE EXPOSURE TIME FOR DIRECT RADIATION CALCULATIONS (hr) EXPTIME $=3$.

C ENTER THE MINIMUM DOWNHIND DISTANCE FOR DISPERSION CALCULATIONS (m) $X M I N=100$.

C ENTER THE MAXIMUM DOWNHIND DISTANCE FOR DISPERSION CALCULATIONS (m) $X M A X=2000$.

C ENTER THE DONNHIND DISTANCE INCREMENT (m) XSTEP $=100$.

C ENTER THE ELEVATION TO BE USED IN DISPERSION CALCULATIONS (m) $Z=0$.

C ENTER THE AMBIENT TEMPERATURE (K) $T A=298$.

C ENTER THE INITIAL PLUME RADIUS (m) $R O=0.5$

C ENTER THE WIND VELOCITY AT AN ELEVATION OF $2 \mathrm{~m}(\mathrm{~m} / \mathrm{s})$ U2 $=1$.

C ENTER THE BREATHING RATE $(\mathrm{m} 3 / \mathrm{hr})$ BREATHE $=1.2$

C ENTER THE VOLUME OF THE WATER TANK (m3) VTANK $=473.175$

C ENTER THE INDIVIDUALS DAILY UPTAKE OF HATER ( $\mathrm{m} 3)$ VDRINK $=0.002$

C

C ALLOW USER TO CHANGE DEFAULT VALUES

C

WRITE(**) 'DEFAULT VALUES ASSUMED BY PROGRAM:'

WRITE $(*, *)$

WRITE(*,220) DIST

WRITE $(*, 230)$ EXPTIME

WRITE $(*, 240)$ XMIN

URITE $(*, 242)$ XMAX

WRITE $(*, 244)$ XSTEP

WRITE (*,250) Z

WRITE $(*, 260)$ TA

WRITE $(*, 270)$ RO

WRITE $(*, 280)$ U2

WRITE $(*, 290)$ BREATHE

URITE $(*, 300)$

URITE $(*, 310)$ VTAHK

URITE $(*, 320)$ VDRINK

$\operatorname{URITE}(*, *)$

WRITE $(* *)$ 'DO YOU WISH TO CHANGE ANY OF THESE VALUES?'

WRITE(*,*) $11=$ YES OR 2 = NO

$\operatorname{HRITE}(* * *)$

READ (*,*) RESPONSE

IF (RESPONSE .EQ. 2) GOTO 5

IF (RESPONSE .EQ. 1) THEN

2

CONTINUE

WRITE $(* *)$ 'ENTER NUMBER OF VARIABLE YOU HISH TO CHANGE'

WRITE $(* * *)$

$\operatorname{READ}(*, *)$ INUM

HRITE $(*, *)$ 'ENTER NEW VALUE'

WRITE $(* *)$

IF (INUM .EQ. 1) READ(*,*) DIST

IF (INUM .EQ. 2) READ(*,*) EXPTIME

IF (INUM .EQ. 3) READ(*,*) XMIN

IF (INUM .EQ. 4) READ(*,*) XMAX

IF (INUM .EQ. 5) READ(*,*) XSTEP

IF (INUM .EQ. 6) READ(*,*) Z

IF (INUM .EQ. 7) READ(*,*) TA

IF (INUM .EQ. 8) READ (*,*) RO

If (INUM .EQ. 9) READ(*,*) U2

IF (INUM .EQ. 10) READ(*,*) BREATHE 


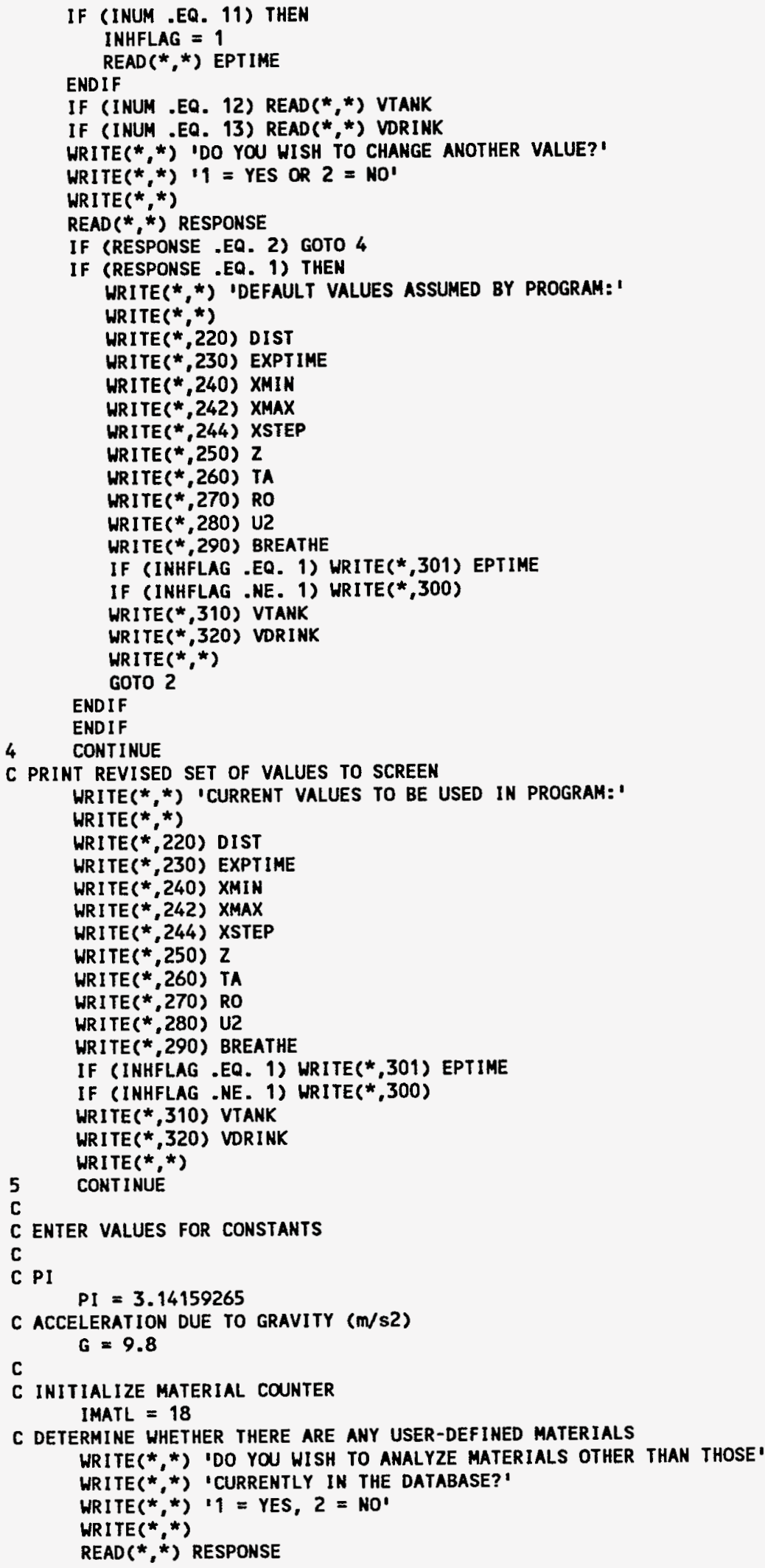




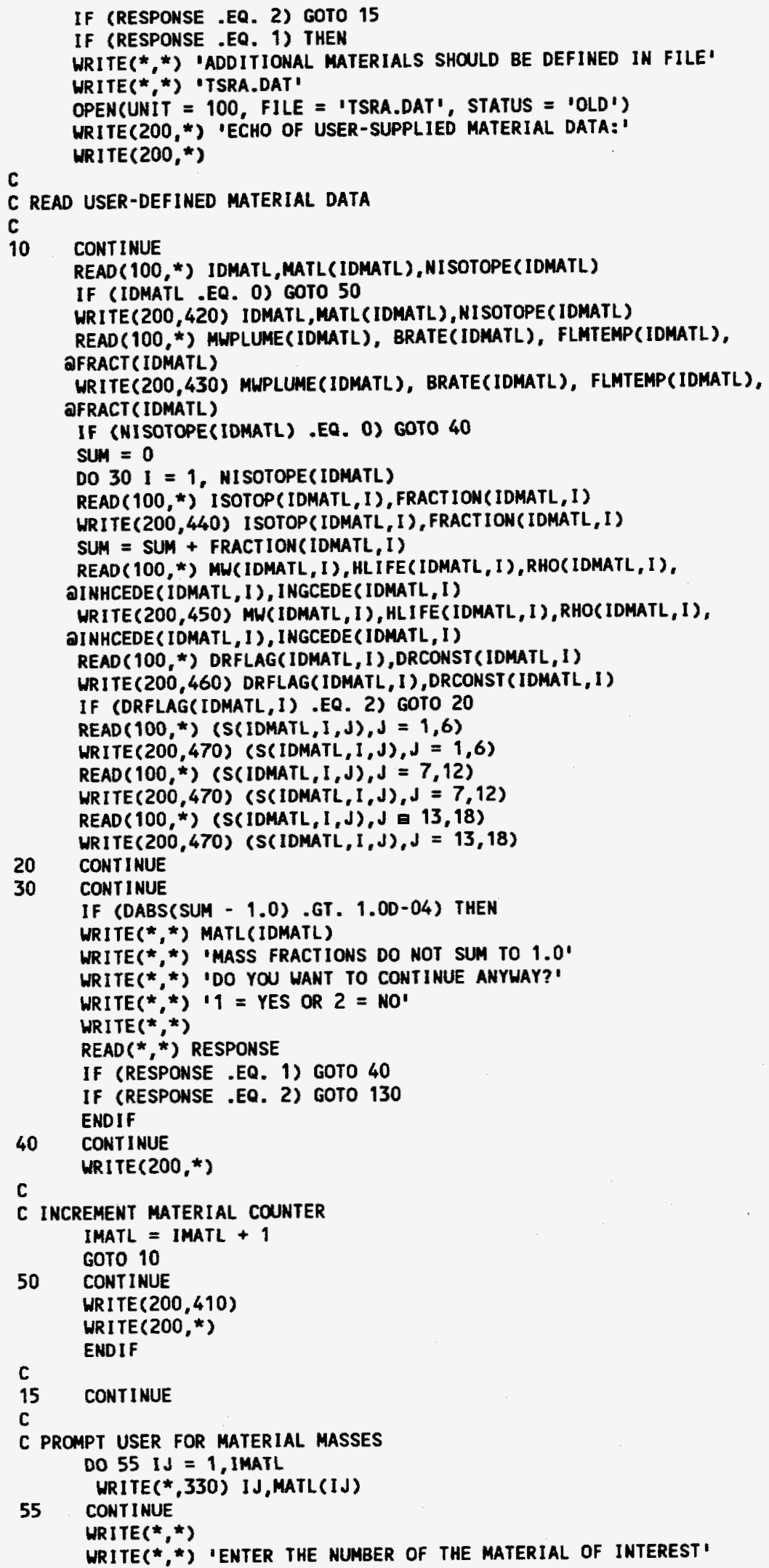




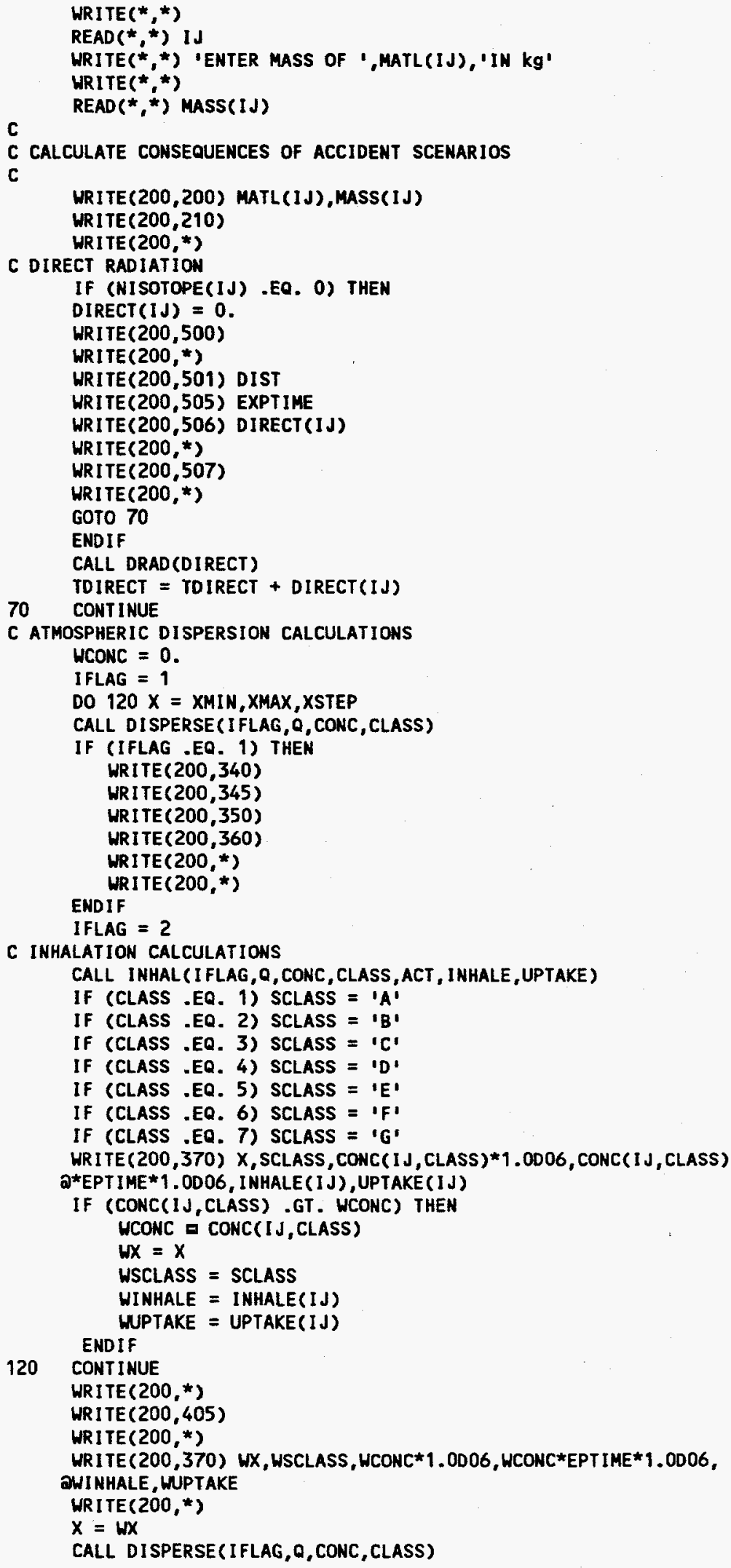


IFLAG $=1$

CALL INHAL (IFLAG, Q, CONC, CLASS, ACT, INHALE, UPTAKE)

TINHALE = TINHALE+WINHALE

C INGESTION CALCULATIONS

CALL HATER (MCONT)

CALL INGST (ACT, MCONT, INGEST, INTAKE)

C

TINGEST = TINGEST + INGEST $(I \mathrm{~J})$

WRITE(**) 'DO YOU HISH TO CHOOSE ANOTHER MATERIAL?'

WRITE $(*, *) 19$ 曰 YES OR $2=$ NO'

URITE $(*, *)$

READ $(*, *)$ RESPONSE

IF (RESPONSE .EQ. 2) GOTO 130

130

IF (RESPONSE .EO. 1) GOTO 15

C URITE TOTAL RADIOLOGICAL DOSES TO OUTPUT FILE

WRITE $(200 *$ *)

WRI TE(200,375)

WRITE(200,380) TDIRECT

WRITE(200,390) TINHALE

C

WRI TE $(200,400)$ TINGEST

C FORMAT STATEMENTS

150 FORMATS

a' ENTER THE NAME (UP TO 8 CHARACTERS) OF THE OUTPUT FILE. DO')

160 FORMATC

a' NOT PROVIDE AN EXTENSION. THE FILE WILL AUTOMATICALLY BE')

170 FORMATC

a' GIVEN THE EXTENSION .OUT')

180 FORMAT(' ENTER A 0 IF YOU WISH TO ACCEPT THE DEFAULT OUTPUT')

190 FORMAT(' NAME OF TSRA.OUT')

200 FORMAT(A30,' [', 1P,E10.4,' kg]')

210 FORMATS

220

230

240

242

244

250

260

270

280

290

300

301

310

320

330

340

FORMAT( ' 1. DISTANCE FROW THE SOURCE $=', F 6.2, ' \mathrm{~m}$ ')

FORMAT(' 2. EXPOSURE TIME FOR DIRECT RADIATION $=1, F 5.2,1 \mathrm{hr}$ ')

FORMAT $\left(13\right.$. MINIMUM DOWNIIMD DISTANCE $\left.=1, F 6.1, \mathrm{~m}^{\prime}\right)$

FORMAT ( ' 4. MAXIMUM DOWNWIND DISTANCE $=', F 6.1, \mathrm{c}^{\prime} \mathrm{m}$ )

FORMAT(' 5. DOWNHIND DISTANCE INCREMENT $=', F 6.1, \mathrm{~m}^{\prime} \mathrm{m}$ )

FORMAT ( 1 6. ELEVATION $=1, F 6.1,1 \mathrm{~m}$ ')

FORMAT ( ' 7. AMBIENT TEMPERATURE $=1, F 6.2,1 \mathrm{~K} \cdot$ )

FORMAT( 1 8. INITIAL PLUME RADIUS $\left.=1, F 5.2, \mathrm{~m}^{\prime} \mathrm{m}^{\prime}\right)$

FORMAT( ' 9. WIND VELOCITY AT AN ELEVATION OF $2 \mathrm{~m}=1, F 5.2,1 \mathrm{~m} / \mathrm{s}^{\prime}$ )

FORMAT(' 10. BREATHING RATE $=1, F 5.2,1 \mathrm{~m} 3 / \mathrm{hr}$ ')

FORMAT( 1 11. EXPOSURE TIME FOR INHALATION = BURN DURATION')

FORMAT( ' 11. EXPOSURE TIME FOR INHALATION $=$ ', F5.2, ' $h r^{\prime}$ ')

FORMAT ( 1 12. VOLUME OF THE WATER TANK $=1, F 6.2, ' \mathrm{~m} 3$ ')

FORMAT(' 13. INDIVIDUAL DAILY UPTAKE OF WATER $=1,76.4,1 \mathrm{~m} 3 \prime$ ')

FORMAT (1 $X, 12, '$. 'A30)

FORMAT( 'DOWnwind', 2X, 'Stability', 2X, 'Concentration', 1X,

a'Concentration', $1 \mathrm{X}$, ' Inhalat ion', 4X, 'Uptake')

345

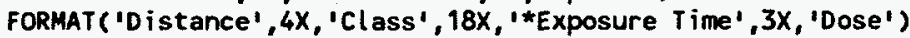

350

FORMAT $\left(3 \mathrm{X},{ }^{\prime}(\mathrm{m}) ', 18 \mathrm{X}, \mathrm{\prime}^{\prime}(\mathrm{mg} / \mathrm{m} 3)^{\prime}, 6 \mathrm{X},{ }^{\prime}(\mathrm{mg}-\mathrm{hr} / \mathrm{m} 3)^{\prime}, 5 \mathrm{X},{ }^{\prime}(\mathrm{rem})^{\prime}, 7 \mathrm{X}\right.$,

a'(mg)'s

360

a'

370 FORMAT(1X,F6.1,7X,A1,8X,1P,E10.4,4X,1P,E10.4,2X,1P,E10.4,2X,1P, aE 10.4)

375 FORMAT('TOTAL RADIOLOGICAL DOSES FOR SHIPMENT: ')

380 FORMAT (5X, 'TOTAL RADIOLOGICAL DOSE DUE TO DIRECT RADIATION = ', DIP,E10.4,' ren')

390 FORMAT( $5 X$, 'TOTAL RADIOLOGICAL DOSE DUE TO INHALATION = ', QIP,E10.4,' rem')

400 FORMAT( $5 X$, 'TOTAL RADIOLOGICAL DOSE DUE TO INGESTION = ', DIP,E10.4,' rem')

405 FORMAT( $5 X$, "WORST CASE VALUES:')

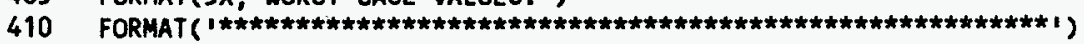


420 FORMAT $(5 X, 12,2 X, A 30,2 X, 12)$

430 FORMAT(5X,1P,E10.4,2X,1P,E10.4,2X,1P,E10.4,2X,1P,E10.4)

440 FORMAT( $5 X, A 6,2 X, 1 P, E 10.4)$

450 FORMAT $(5 X, 1 P, E 10.4,2 X, 1 P, E 10.4,2 X, 1 P, E 10.4,2 X, 1 P, E 10.4,2 X, 1 P$, DE 10.4)

460 FORMAT $(5 X, 11,2 X, 1 P, E 10.4)$

470 FORMAT ( $5 X, 1 P, E 10.4,2 X, 1 P, E 10.4,2 X, 1 P, E 10.4,2 X, 1 P, E 10.4,2 X, 1 P$, DE10.4,2X, 1P,E10.4)

500 FORMAT('DIRECT RADIATION EXPOSURE:' ')

501 FORMAT ( $5 X$, 'DISTANCE FROM SOURCE $=1, F 6.2,1 \mathrm{~m} '$ )

505 FORMAT(5X, 'EXPOSURE TIME $=1$, F5.2,' hours')

506 FORMAT (5X, 'DOSE DUE TO DIRECT RADIATION $=1,1 \mathrm{P}, \mathrm{E} 10.4,1$ rem')

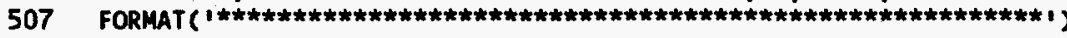

END 


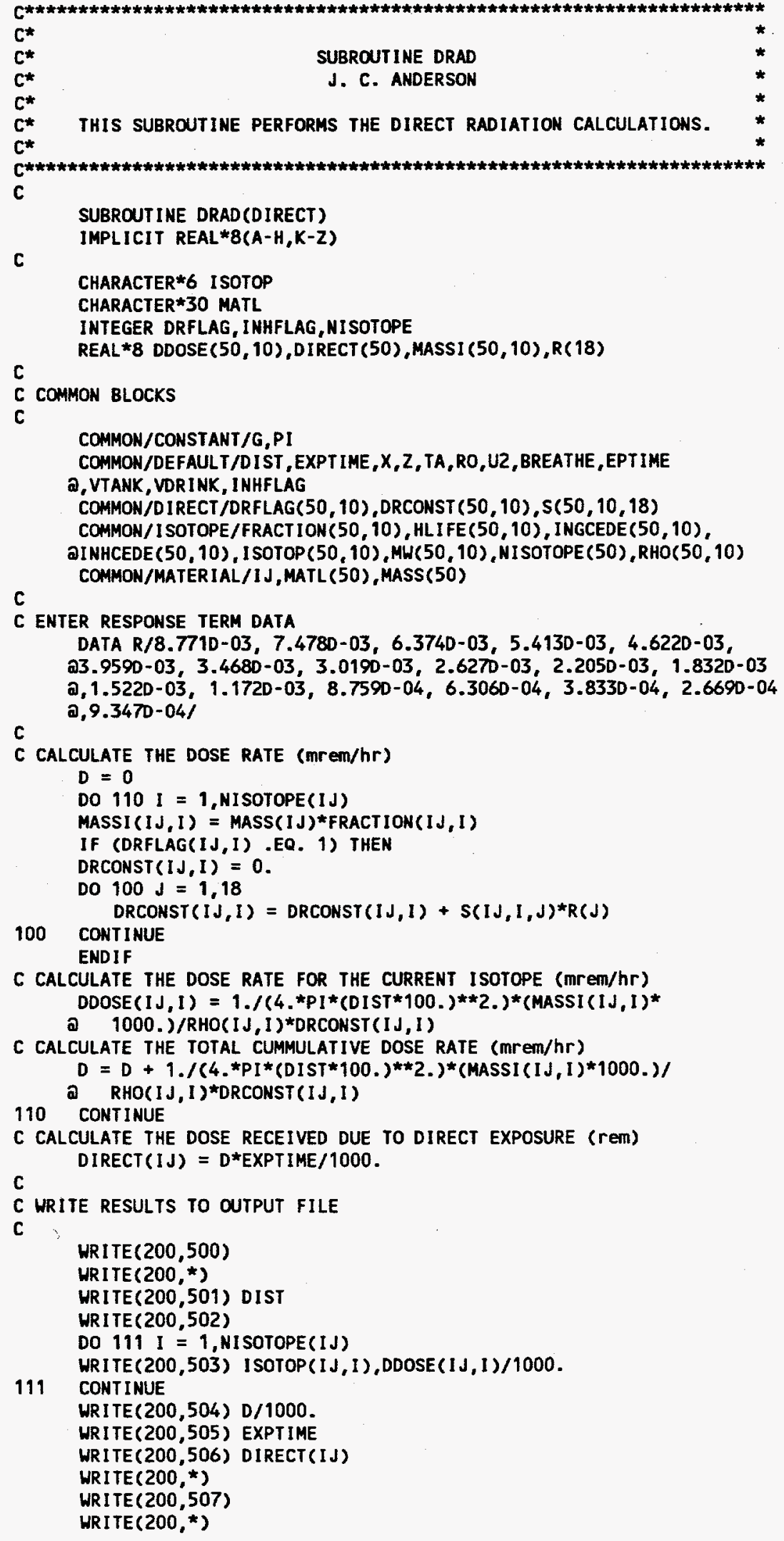




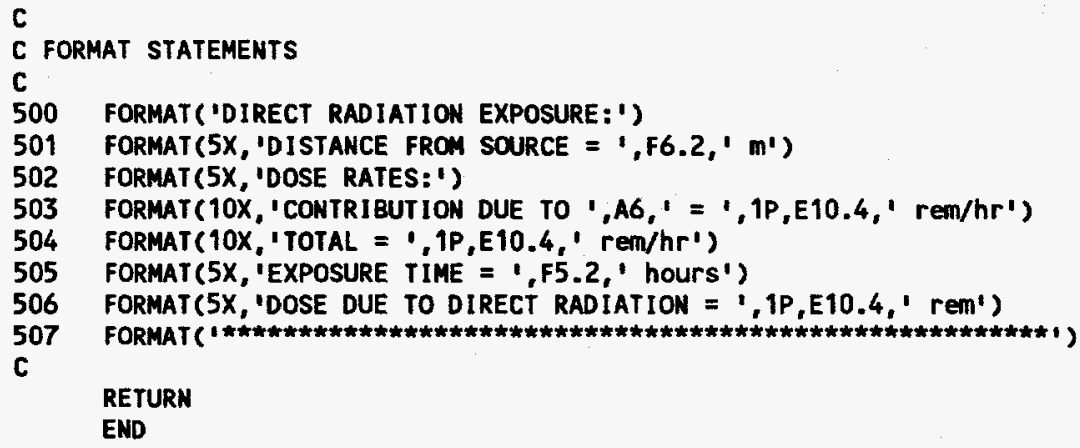




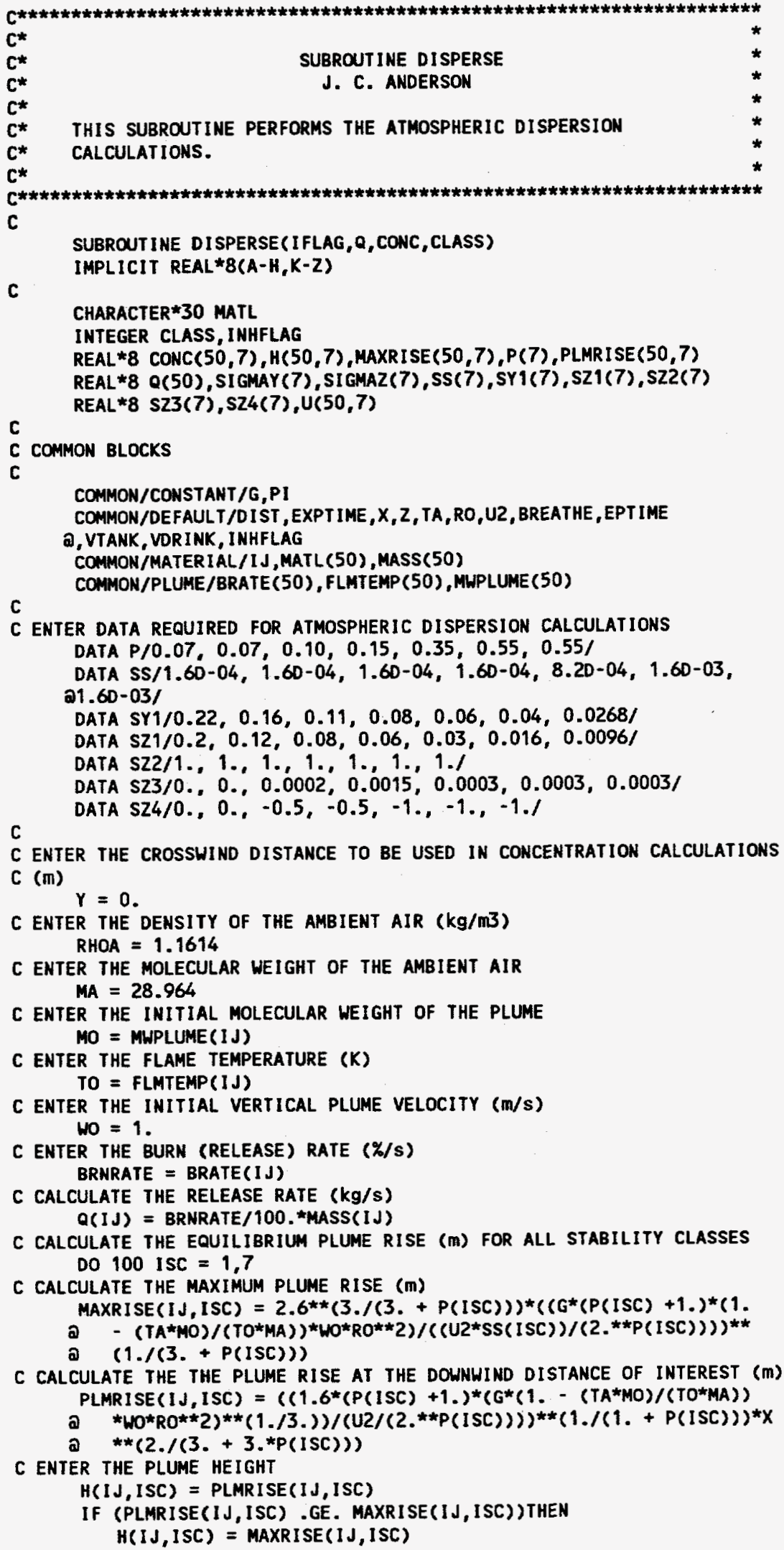

C ENTER THE CROSSWIND DISTANCE TO BE USED IN CONCENTRATION CALCULATIONS C (m) $Y=0$.

C ENTER THE DENSITY OF THE AMBIENT AIR $(\mathrm{kg} / \mathrm{m} 3)$ RHOA $=1.1614$

C ENTER THE MOLECULAR WEIGHT OF THE AMBIENT AIR $M A=28.964$

C ENTER THE INITIAL MOLECULAR WEIGHT OF THE PLUME MO $=$ MUPLUME $(I J)$

C ENTER THE FLAME TEMPERATURE (K) TO = FLMTEMP (IJ)

C ENTER THE INITIAL VERTICAL PLUME VELOCITY $(\mathrm{m} / \mathrm{s})$ WO $=1$.

C ENTER THE BURN (RELEASE) RATE (\%/s) BRNRATE = BRATE $(I \mathrm{~J})$

C CALCULATE THE RELEASE RATE ( $\mathrm{kg} / \mathrm{s})$ $Q(I J)=$ BRNRATE $/ 100$. *MASS $(I J)$

C CALCULATE THE EQUILIBRIUM PLUME RISE (m) FOR ALL STABILITY CLASSES DO $10015 C=1,7$

C CALCULATE THE MAXIMUM PLUME RISE (m) MAXRISE $(I J, I S C)=2.6 * \star(3 . /(3 .+P(I S C)))^{*}\left(\left(G^{*}(P(I S C)+1) *.(1\right.\right.$. a $\left.\left.\left.-\left(T A^{\star M O}\right) /\left(T O^{*} M A\right)\right)^{*} W O^{*} R O^{* *} 2\right) /((U 2 * S S(I S C)) /(2 . * * P(I S C)))\right) * *$ a $(1 . /(3 .+P(I S C)))$

C CALCULATE THE THE PLUME RISE AT THE DOWNWIND DISTANCE OF INTEREST (m) PLMRISE $(1 \mathrm{~J}, 1 \mathrm{ISC})=\left(\left(1.6^{\star}(P(1 S C)+1 .)^{*}\left(G^{*}\left(1 .-\left(T A^{\star} M O\right) /\left(T O^{\star} M A\right)\right)\right.\right.\right.$ a $\left.\left.\left.* W_{0} R_{0} 0^{*} 2\right) * *(1 . / 3).\right) /(U 2 /(2 . * * P(I S C)))\right) * *(1 . /(1 .+P(I S C))) * X$ a $* *(2 . /(3 .+3 . * P(I S C)))$

C ENTER THE PLUME HEIGHT $H(I J, I S C)=$ PLMRISE $(I J, I S C)$ IF (PLMRISE(IJ,ISC) .GE. MAXRISE(IJ,ISC)) THEN $H(I J, I S C)=\operatorname{MAXRISE}(I J, I S C)$ 
ENDIF

C CALCULATE THE AVERAGE AMBIENT HIND VELOCITY $(\mathrm{m} / \mathrm{s})$

$U(I J, I S C)=U 2 *(H(I J, I S C) / 2) * * P.(I S C) /(P(I S C)+1$.

C CALCULATE THE CROSSWIND DISPERSION COEFFICIENT (m)

SIGMAY ISC $)=\operatorname{SYI}(I S C) * X *(1 .+0.0001 * X) * *(-0.5)$

C CALCULATE THE VERTICAL DISPERSION COEFFICIENT

SIGMAZ(ISC) $=$ SZ1 (ISC)*X*(SZ2(ISC) + SZ3 (ISC)*X)**(SZ4(ISC))

C CALCULATE THE CONCENTRATION USING THE STANDARD GAUSSIAN DISPERSION

C EQUATION ( $\mathrm{kg} / \mathrm{m} 3$ )

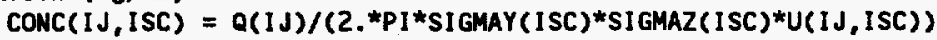

a DEXP $-\gamma * \star 2.1(2 . * \operatorname{SIGMAY}(I S C) * \star 2)) *.(\operatorname{DEXP}(-(Z-H(I J, I S C)) * * 2.1$

a $(2 . * \operatorname{SIGMAZ}(1 S C) * 2)).+\operatorname{DEXP}(-(Z+H(I J, I S C)) * * 2.1(2 . * S I G M A Z$

100 CONTINUE

C DETERMINE THE WORST CASE CONCENTRATION AND THE ASSOCIATED STABILITY

C CLASS

WORST $=0$

DO 110 ISC $=1,7$

IF (CONC(IJ,ISC) .GT. WORST) THEN

WORST $=\operatorname{CONC}(I \mathrm{~J}, I S C)$

CLASS $=$ ISC

ENDIF

110 CONTINUE

C WRITE RESULTS TO OUTPUT FILE

IF (IFLAG .EQ. 1) THEN

WRITE $(200,600)$

WRITE $(200, *)$

WRITE $(200,602)$ TA

URITE $(200,605)$ MA

WRI TE (200,608) RHOA

URITE $(200,610)$ U2

URITE $(200, *)$

WRITE $(200,603)$ MO

WRITE $(200,604)$ TO

WRITE $(200,606)$ RO

WRITE $(200,607)$ Q(IJ)

WRITE $(200,609)$ Wo

WRITE $(200$, *)

WRI TE $(200,613) Y$

WRITE $(200,614) Z$

URITE $(200,615)$ EPTIME

WRITE $(200,616)$ BREATHE

WRITE $(200, *)$

ENDIF

C FORMAT STATEMENTS

600 FORMAT('ATMOSPHERIC DISPERSION CALCULATIONS:')

602 FORMAT (5X,'Ambient Properties: ' $6 \mathrm{X}$, ' AMBIENT TEMPERATURE = 1

a, F6.1, ' $K$ ')

603 FORMAT(5X,'Plume Properties: ' , 8X, 'MOLECULAR UEIGHT OF PLUME $=$ '

a, F6.2)

604 FORMAT (30X,' FLAME TEMPERATURE $=1, F 6.1,1 \mathrm{~K}$ ')

605 FORMAT (30X, 'MOLECULAR WEIGHT OF AMBIENT AIR $=1, F 6.2$ )

606 FORMAT(30X,'INITIAL PLUME RADIUS $\left.=1,75.2, \mathrm{~m}^{\prime}\right)$

607 FORMAT (30X,'BURN RATE $=1,1 P, E 10.4,1 \mathrm{~kg} / \mathrm{s}^{\prime}$ )

608 FORMAT (30X, 'DENSITY OF AMBIENT AIR $=1,1 \mathrm{P}, \mathrm{E} 10.4,1 \mathrm{~kg} / \mathrm{m} 3^{\prime}$ ')

609 FORMAT(30X,'INITIAL VERTICAL PLUME VELOCITY $\left.=1,55.2,1 \mathrm{~m} / \mathrm{s}^{\prime}\right)$

610 FORMAT (30X, 'WIHD VELOCITY AT $2 \mathrm{~m}=1, F 5.2,1 \mathrm{~m} / \mathrm{s}^{\prime}$ )

612 FORMAT ( $30 X$, 'BURN TIME $\left.=1,1 P, E 10.4,1 \mathrm{~s}^{\prime}\right)$

613 FORMAT $(5 x$, 'Receptor Information: $1,4 x$, ' CROSSWIND DISTANCE $=1$

Q, $\left.1 \mathrm{P}, \mathrm{E} 10.4, \mathrm{~g}^{\prime} \mathrm{m}^{\prime}\right)$

614 FORMAT(30X, 'ELEVATION OF RECEPTOR $\left.=1,1 \mathrm{P}, E 10.4, \mathrm{~g}^{\mathrm{m}} \mathrm{m}\right)$

615 FORMAT (30X, 'EXPOSURE TIME $=1,1 \mathrm{P}, \mathrm{E} 10.4, \mathrm{~h} \mathrm{hr}$ ')

616 FORMAT (30X, 'BREATHING RATE $=1, \mathrm{F5} .2,1 \mathrm{m3} / \mathrm{hr}$ ')

C 
RETURN

END 


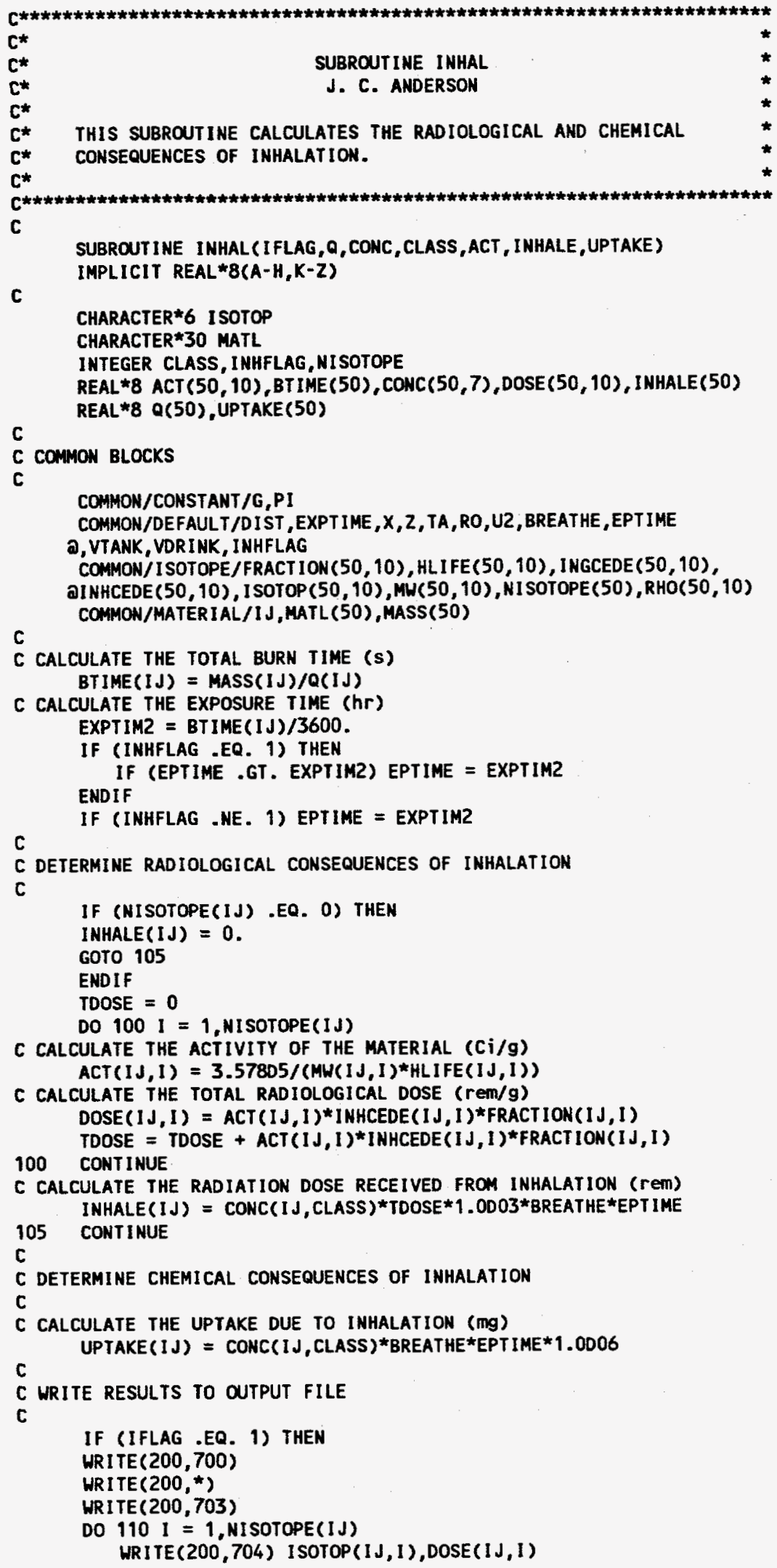


110 CONTINUE

WRITE $(200,705)$ TDOSE

WRITE(200,706) INHALE(IJ)

WRITE $(200, *)$

WRI TE $(200,707)$

$\operatorname{HRITE}(200, *)$

WRITE $(200,708)$ UPTAKE(IJ)

WRI TE $(200, *)$

WRITE(200,709)

WRITE $(200, *)$

ENDIF

C

C FORMAT STATEMENTS

700

703

704

705

706

707

708

709

FORMAT('MAXIMUM RADIOLOGICAL CONSEOUENCES OF INHALATION: ')

FORMAT (5X, 'RADIOLOGICAL DOSES: ')

FORMAT (10X, 'CONTRIBUTION DUE TO ',A6, ' $=1,1 \mathrm{P}, \mathrm{E} 10.4, \mathrm{l}^{\prime} \mathrm{rem} / \mathrm{g}^{\prime}$ ')

FORMAT (10X,'TOTAL = ',1P,E10.4,' rem/g')

FORMAT (5X, 'DOSE DUE TO INHALATION = ', 1 P,E10.4,' rem')

FORMAT ('MAXIMUM CHEMICAL CONSEQUENCES OF INHALATION: ')

FORMAT ( $5 X$, 'UPTAKE DUE TO INHALATION $=1,1 P, E 10.4, ' \mathrm{mg}$ ')

c.

RETURN

END 


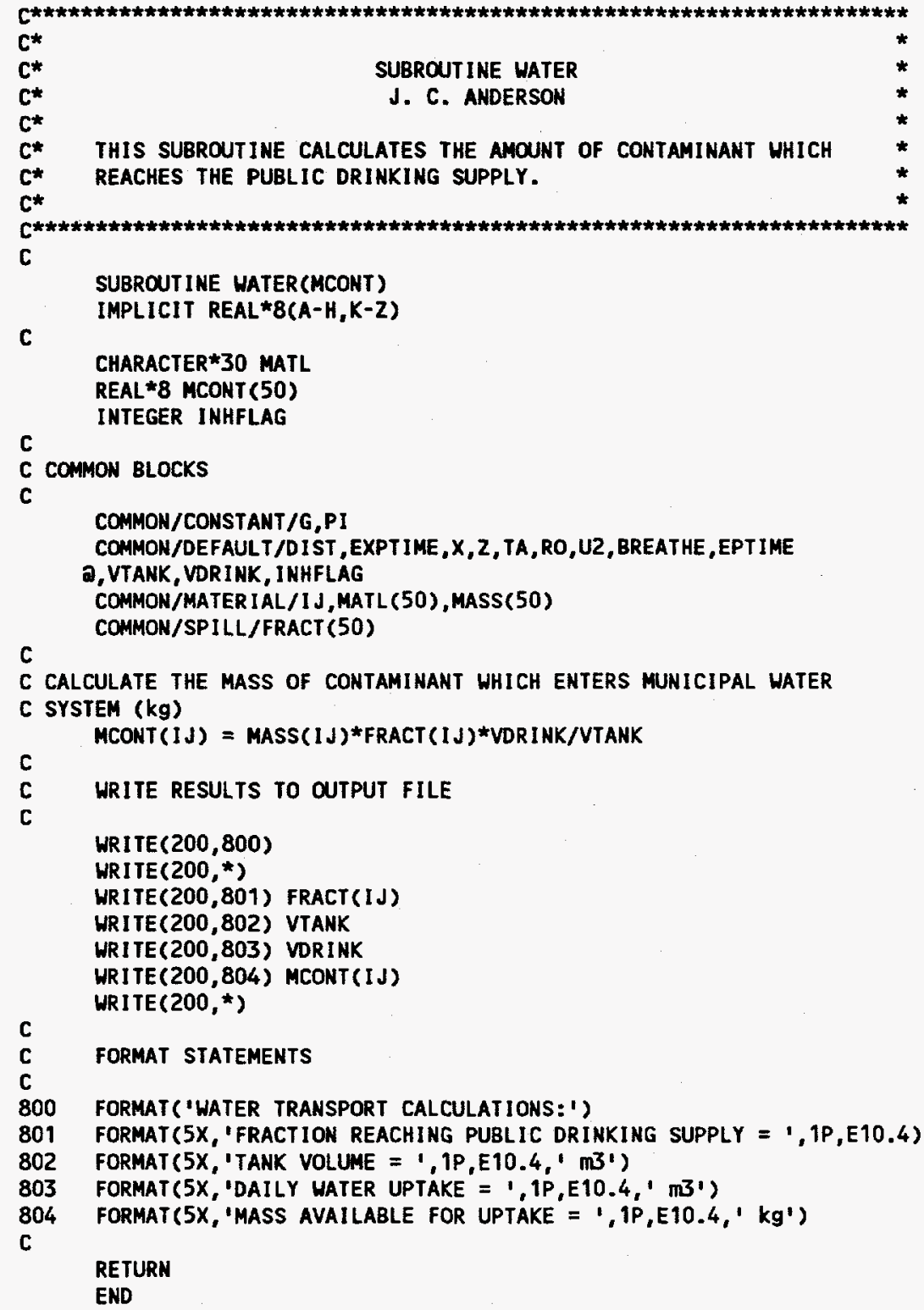




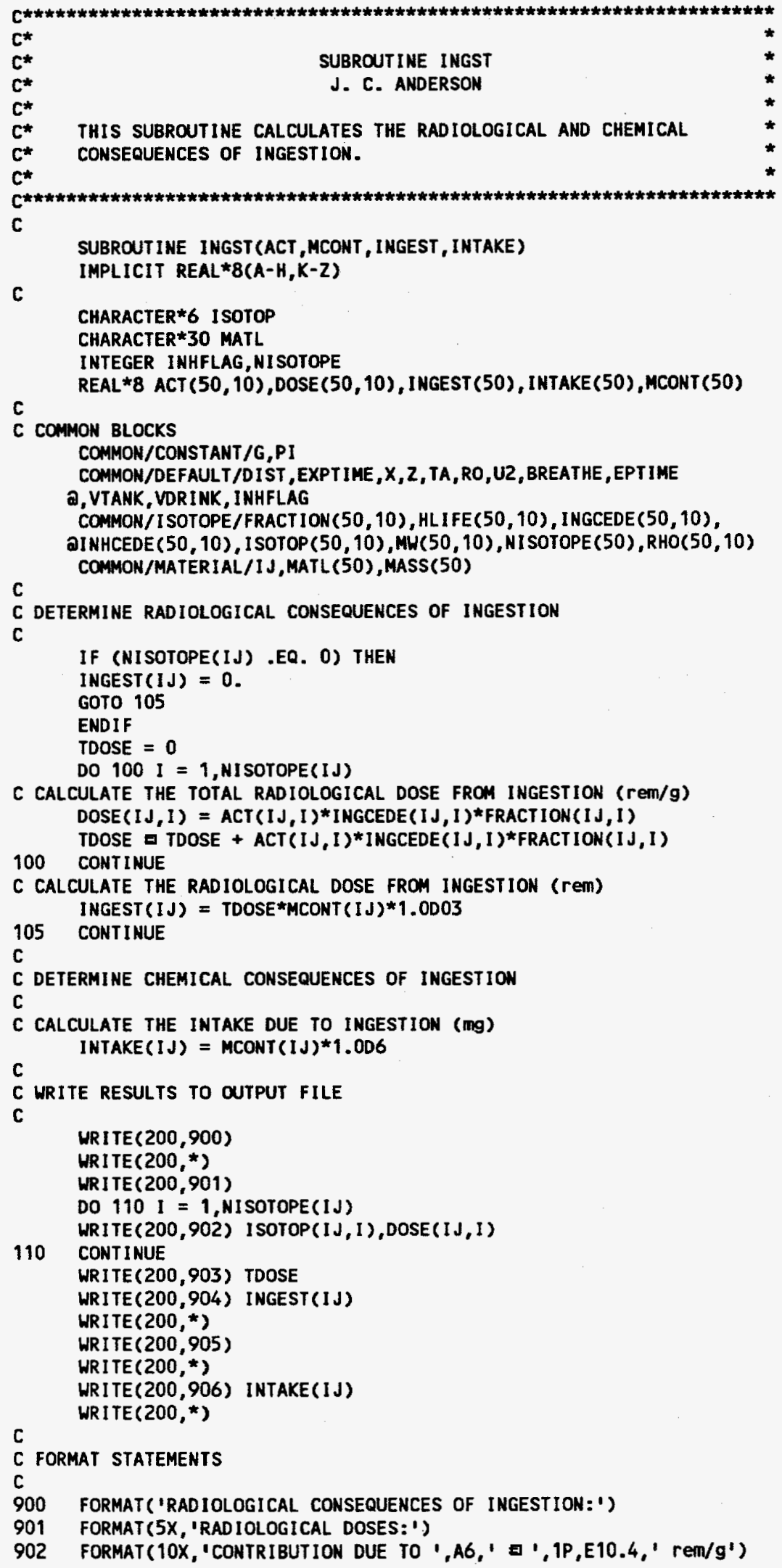


903 FORMAT(10X,'TOTAL $\left.=1,1 \mathrm{P}, \mathrm{E} 10.4, \mathrm{I}^{\prime} \mathrm{rem} / \mathrm{g}^{\prime}\right)$

904 FORMAT ( $5 X$, 'DOSE DUE TO INGESTION $=1,1 \mathrm{P}, \mathrm{E10} .4, \mathrm{r}^{1} \mathrm{rem}$ ')

905 FORMAT( 'CHEMICAL CONSEQUENCES OF INGESTION:')

906 FORMAT (5X,'INTAKE DUE TO INGESTION = ',1P,E10.4,' $\mathrm{mg}$ ')

RETURN

END 


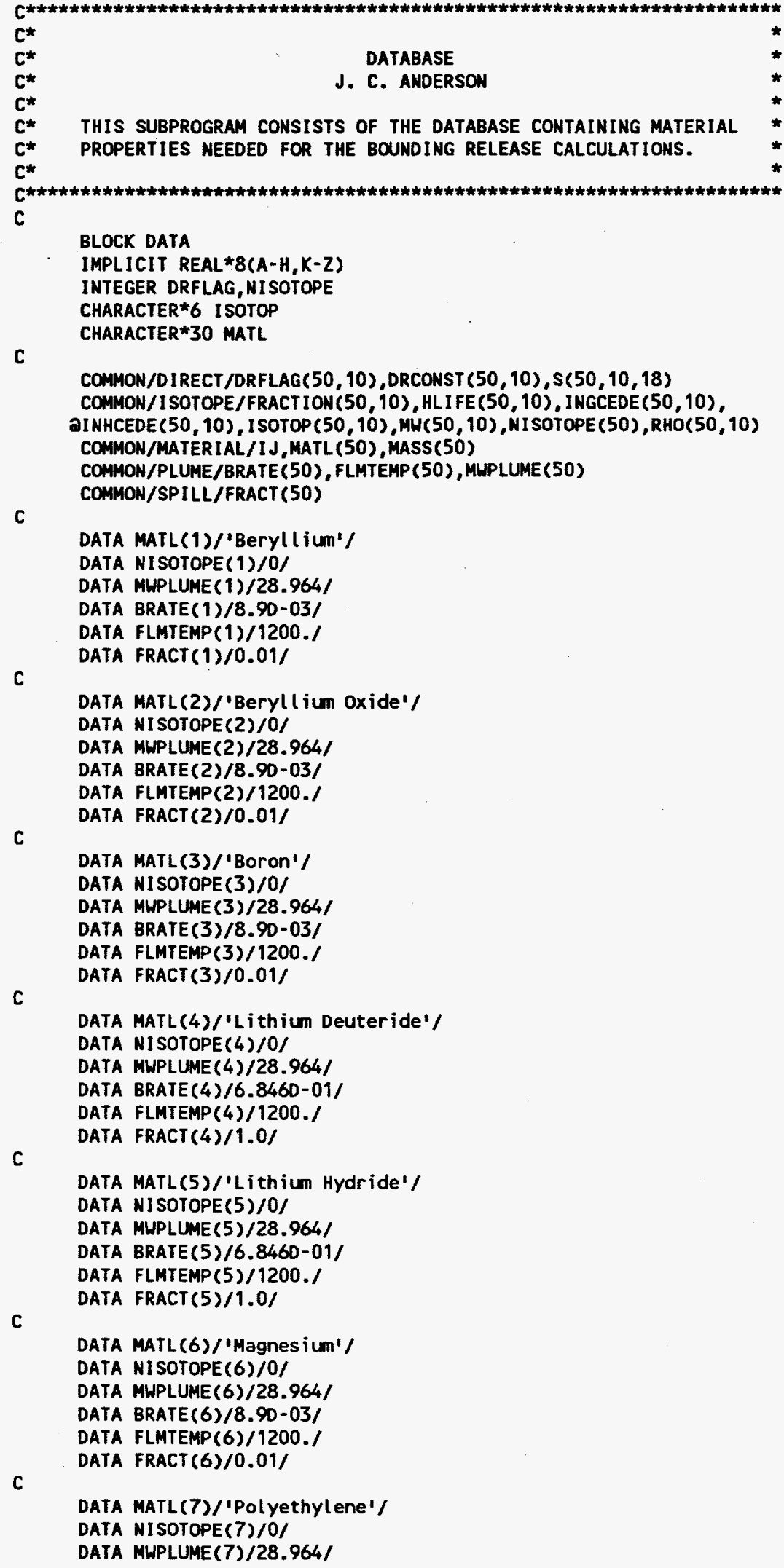


DATA BRATE(7)/8.90-03/

DATA FLMTEMP(7)/1200./

DATA FRACT(7)/0.01/

C

DATA MATL(8)/'Polyethylpentene'/

DATA NISOTOPE $(8) / 0 /$

DATA MWPLUME(8)/28.964/

DATA BRATE(8)/8.90-03/

DATA FLMTEMP(8)/1200./

C

DATA FRACT(8)/0.01/

DATA MATL(9)/'silicone'/

DATA NISOTOPE( 9$) / 0 /$

DATA MWPLUME( 9$) / 28.964 /$

DATA BRATE(9)/8.9D-03/

DATA FLMTEMP $(9) / 1200 . /$

C

DATA FRACT(9)/0.01/

DATA MATL(10)/'Tantalum'/

DATA NISOTOPE (10)/0/

DATA MWPLUME(10)/28.964/

DATA BRATE(10)/8.90-03/

DATA FLMTEMP(10)/1200./

c

DATA FRACT(10)/0.01/

DATA MATL(11)/'Thoriun'/

DATA NISOTOPE(11)/1/

DATA MWPLUME(11)/28.964/

DATA BRATE(11)/8.90-03/

DATA FLMTEMP(11)/1200./

DATA FRACT(11)/0.01/

DATA ISOTOP $(11,1) /$ 'Th-232'/

DATA FRACTION $(11,1) / 1.0 /$

DATA MW(11,1)/232.038054/

DATA HLIFE $(11,1) / 1.4010 /$

DATA RHO(11,1)/11.7/

DATA INHCEDE $(11,1) / 1.6009 /$

DATA INGCEDE $(11,1) / 2.8 D 06 /$

DATA DRFLAG $(11,1) / 21$

DATA DRCONST $(11,1) / 262.81$

C

DATA MATL(12)/'Tungsten'/

DATA NISOTOPE(12)/0/

DATA MWPLUME(12)/28.964/

DATA BRATE(12)/8.9D-03/

DATA FLMTEMP(12)/1200./

DATA FRACT(12)/0.01/

C

DATA MATL(13)/'Highly Enriched Uranium'/

DATA NISOTOPE (13)/5/

DATA MUPLUME(13)/28.964/

DATA BRATE(13)/8.90-03/

DATA FLMTEMP (13)/1200./

DATA FRACT(13)/0.01/

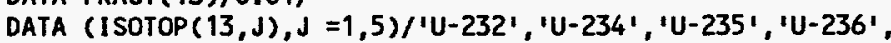
QU-2381

DATA (FRACTION $(13, \mathrm{~J}$ ), J=1,5)/4.00-08,0.012,0.94,0.0048,0.04319996/ DATA (MW(13,J), J=1,5)/232.03713,234.040946,235.043924,236.045562, 2238.050784/

DATA (HLIFE(13, J), J=1,5)/68.9,2.45D05,7.04D08,2.34D07,4.46D09/

DATA $(R H O(13, J), J=1,5) / 18.57,18.72,18.81,18.89,19.05 /$

DATA (INHCEDE $(13, J), J=1,5) / 6.7 D 08,1.3 D 08,1.2 D 08,1.2 D 08,1.2 D 08 /$

DATA (INGCEDE (13,J), J=1,5)/1.3D06,2.6005,2.5005,2.5005,2.3005/

DATA CDRFLAG $(13, j), j=1,5) / 5 * 1 /$

DATA CDRCONST $(13, j), J=1,5) / 5 * 0 /$

DATA $(S(13,1, j), j=1,18) / 1.744001,1.306002,1.027003,3.562 D 03$,

a1.408004,4.563012,4.517006,4.378010,4.770D 11, 1.502D11,7.149011, a2.080D12,6.026012,3.518011,7.191D12,7.405011,6.771D12,5.533012/ 
DATA $(S(13,2, J), J=1,18) / 1.0080-03,7.3590-03,5.6960-02$, a1.961D-01,2.786001,1.190002,7.181003,1.880004,1.126004, 22.218004,5.088003,4.300004,5.580003,3.415004,2.899004, Q1.401D06,3.652006,1.950008/

DATA $(s(13,3, J), J=1,18) / 6.573 D-06,3.1880-05,1.693 D-04$, Q4.4090-04, 1.373D-03, 1.594D-03,2.846D-03,4.881D-03,3.4470-05 a, 2.862000,6.911001,3.932001,3.289002,3.037003,7.224004, a1.318006,3.044005,5.301005/

DATA $(S(13,4, J), J=1,18) / 9.6420-05,4.815 D-04,2.6580-03,7.1900-03$, a2.3290-02,5.754D-02,5.100D-02,9.078D-02,1.348D-02,2.065D-01, a6.182D-02,4.755D-01,4.843D-02,1.773D-02,7.087D-01,6.457D03, Q5.182D-02,6.614D-02i

DATA $(S(13,5, J), J=1,18) / 1.9290-04,9.0870-04,4.632 D-03$, a1.154D-02,3.4200-02,3.8060-02,4.075D-01,1.600D02,1.616002, จ9.743002,1.772003,2.360003,3.240003,4.756003,6.656003,

DATA MATL(14)/'Natural Uranium'/

DATA NISOTOPE(14)/3/

DATA MUPLUME(14)/28.964/

DATA BRATE(14)/8.90-03/

DATA FLMTEMP(14)/1200./

DATA FRACT(14)/0.01/

DATA (ISOTOP $(14, \mathrm{~J}), \mathrm{J}=1,3) / \cdot U-234^{\prime}, \mathrm{U} U-235^{\prime}, \mathrm{U} U-238 \cdot /$

DATA (FRACTION $(14, \mathrm{~J}), \mathrm{J}=1,3$ ) $/ 0.000056,0.007050,0.992894 /$

DATA (MW(14,J), J=1,3)/234.040946,235.043924,238.050784/

DATA (HLIFE $(14, \mathrm{~J}), \mathrm{J}=1,3) / 2.45005,7.04008,4.46009$ /

DATA (RHO $(14, J), J=1,3) / 18.72,18.81,19.05$ /

DATA (INHCEDE $(14, \mathrm{~J}), \mathrm{J}=1,3) / 1.3008,1.2008,1.2008 /$

DATA (INGCEDE $(14, \mathrm{~J}), \mathrm{J}=1,3) / 2.6005,2.5005,2.3005$ /

DATA CDRFLAG $(14, j), J=1,3) / 3 * 1 /$

DATA (DRCONST $(14, \mathrm{~J}), \mathrm{J}=1,3) / 3 * 0 /$

DATA $(s(14,1, J), J=1,18) / 1.0080-03,7.3590-03,5.6960-02$, a1.9610-01,2.786001, 1.190002,7.181003,1.880004,1.126004, a2.218D04,5.088003,4.300004,5.580003,3.415004,2.899004, a1.401006,3.652006,1.950008;

DATA $(S(14,2, J), J=1,18) / 6.5730-06,3.1880-05,1.6930-04$, Q4.4090-04,1.3730-03,1.5940-03,2.8460-03,4.8810-03,3.4470-05 a, 2.862000,6.911001,3.932001,3.289002,3.037003,7.224004, a1.318006,3.044005,5.301005/

DATA $(S(14,3, \mathrm{~J}), \mathrm{J}=1,18) / 1.9290-04,9.0870-04,4.6320-03$, จ1.1540-02,3.4200-02,3.8060-02,4.075D-01,1.600002,1.616002, a9.743002,1.772003,2.360003,3.240003,4.756003,6.656003,

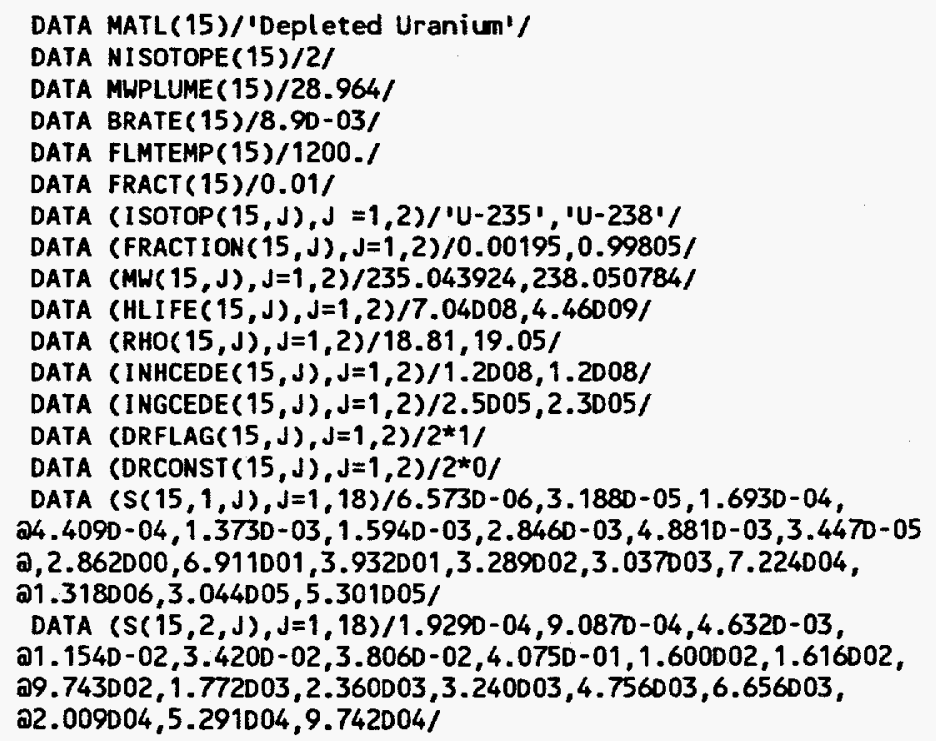


DATA MATL(16)/'Uranium-Niobium Alloy'/

DATA NISOTOPE $(16) / 2 /$

DATA MUPLUME(16)/28.964/

DATA BRATE $(16) / 8.90-03 /$

DATA FLMTEMP $(16) / 1200 . /$

DATA FRACT(16)/0.01/

DATA (ISOTOP $(16, J), J=1,2) / \mathrm{U}-235$ ', $\mathrm{U} U-238$ '/

DATA (FRACTION(16, J), J=1,2)/0.0018486, 0.9461514/

DATA (MH(16, J), J=1, 2)/235.043924, 238.050784/

DATA (HLIFE( $16, j), J=1,2) / 7.04008,4.46009 /$

DATA (RHO $(16, J), J=1,2) / 18.81,19.05 /$

DATA (INHCEDE $(16, \mathrm{~J}), \mathrm{J}=1,2) / 1.2008,1.2008 /$

DATA (INGCEDE $(16, \mathrm{~J}), \mathrm{J}=1,2) / 2.5005,2.3005 /$

DATA (DRFLAG $(16, j), j=1,2) / 2 * 1 /$

DATA (DRCONST $(16, \mathrm{~J}), \mathrm{J}=1,2) / 2 * 0 /$

DATA $(S(16,1, J), J=1,18) / 6.573 D-06,3.1880-05,1.693 D-04$,

$24.4090-04,1.373 \mathrm{D}-03,1.594 \mathrm{D}-03,2.846 \mathrm{D}-03,4.881 \mathrm{D}-03,3.447 \mathrm{D}-05$

a, 2.862000,6.911D01,3.932D01,3.289002,3.037003,7.224D04,

a1.318006,3.044005,5.301005/

DATA $(s(16,2, J), J=1,18) / 1.9290-04,9.087 D-04,4.632 D-03$, a1.154D-02,3.420D-02,3.806D-02,4.075D-01,1.600D02,1.616D02, a9.743002,1.772003,2.360003,3.240003,4.756003,6.656003, a2.009004,5.291004,9.742004/

C

DATA MATL(17)/'Uranium-Niobium-Zirconium ALloy'/

DATA NISOTOPE (17)/2/

DATA MWPLUME(17)/28.964/

DATA BRATE(17)/8.90-03/

DATA FLMTEMP(17)/1200./

DATA FRACT(17)/0.01/

DATA (I SOTOP $(17, \mathrm{~J}), \mathrm{J}=1,2) / \mathrm{U}-235 \mathrm{\prime}, \mathrm{U} \mathrm{U}-2381 /$

DATA (FRACTION(17,J), J=1,2)/1.7550-03,8.982450-01/

DATA (NW(17, J), J=1, 2)/235.043924, 238.050784/

DATA (HLIFE $(17, \mathrm{~J}), \mathrm{J}=1,2) / 7.04008,4.46009 /$

DATA (RHO(17, J), J=1,2)/18.81, 19.05/

DATA (INHCEDE $(17, J), J=1,2) / 1.2008,1.2008 /$

DATA (INGCEDE $(17, j), J=1,2) / 2.5005,2.3005 /$

DATA (DRFLAG $(17, \mathrm{~J}), \mathrm{J}=1,2) / 2 * 1 /$

DATA CDRCONST $(17, j), j=1,2) / 2 * 0 /$

DATA $(s(17,1, J), J=1,18) / 6.5730-06,3.1880-05,1.6930-04$

$24.4090-04,1.3730-03,1.594 \mathrm{D}-03,2.8460-03,4.8810-03,3.447 \mathrm{D}-05$ $0,2.862000,6.911001,3.932001,3.289002,3.037003,7.224004$, 21.318006,3.044005,5.301D05/

DATA $(S(17,2, J), J=1,18) / 1.9290-04,9.0870-04,4.6320-03$, 21.154D-02,3.4200-02,3.8060-02,4.075D-01,1.600002,1.616002, $29.743002,1.772003,2.360003,3.240003,4.756003,6.656003$, a2.009004,5.291004,9.742004/

DATA MATL(18)/'Urethane'/

DATA NISOTOPE (18)/0/

DATA MWPLUME(18)/28.964/

DATA BRATE( 18$) / 8.90-03 /$

DATA FLMTEMP (18)/1200.1

DATA FRACT(18)/0.01/

END 
APPENDIX B

Sample Input and Output 


\section{Screen Dump for Run without User-Supplied Materials}

\section{C:ITSRAITSRA}

32-bit Power for Lahey Computer Systems

Phar Lap's 386|DOS-Extender(tm) Version 5.1

Copyright (C) 1986-93 Phar Lap Software, Inc.

Available Memory $=14580 \mathrm{~Kb}$

ENTER THE NAME (UP TO 8 CHARACTERS) OF THE OUTPUT FILE. DO NOT PROVIDE AN EXTENSION. THE FILE WILL AUTOMATICALLY BE GIVEN THE EXTENSION .OUT

\section{ENTER A 0 IF YOU WISH TO ACCEPT THE DEFAULT OUTPUT}

\section{REPORT}

DEFAULT VALUES ASSUMED BY PROGRAM:

1. DISTANCE FROM THE SOURCE $=152.40 \mathrm{~m}$

2. EXPOSURE TIME FOR DIRECT RADIATION $=3.00 \mathrm{hr}$

3. MINIMUM DOWNWIND DISTANCE $=100.0 \mathrm{~m}$

4. MAXIMUM DOWNWIND DISTANCE $=2000.0 \mathrm{~m}$

5. DOWNWIND DISTANCE INCREMENT $=100.0 \mathrm{~m}$

6. ELEVATION $=0.0 \mathrm{~m}$

7. AMBIENT TEMPERATURE $=298.00 \mathrm{~K}$

8. INITIAL PLUME RADIUS $=0.50 \mathrm{~m}$

9. WIND VELOCITY AT AN ELEVATION OF $2 \mathrm{~m}=1.00 \mathrm{~m} / \mathrm{s}$

10. BREATHING RATE $=1.20 \mathrm{~m} 3 / \mathrm{hr}$

11. EXPOSURE TIME FOR INHALATION $=$ BURN DURATION

12. VOLUME OF THE WATER TANK $=473.17 \mathrm{~m} 3$

13. INDIVIDUAL DAILY UPTAKE OF WATER $=0.0020 \mathrm{~m} 3$

DO YOU WISH TO CHANGE ANY OF THESE VALUES?

$1=$ YES OR $2=$ NO

2

DO YOU WISH TO ANALYZE MATERIALS OTHER THAN THOSE

CURRENTLY IN THE DATABASE?

$1=$ YES, $2=$ NO

2

1. Beryllium

2. Beryllium Oxide

3. Boron

4. Lithium Deuteride

5. Lithium Hydride 
6. Magnesium

7. Polyethylene

8. Polyethylpentene

9. Silicone

10. Tantalum

11. Thorium

12. Tungsten

13. Highly Enriched Uranium

14. Natural Uranium

15. Depleted Uranium

16. Uranium-Niobium Alloy

17. Uranium-Niobium-Zirconium Allo

18. Urethane

\section{ENTER THE NUMBER OF THE MATERIAL OF INTEREST}

13

ENTER MASS OF Highly Enriched Uranium IN kg

10

DO YOU WISH TO CHOOSE ANOTHER MATERIAL?

$1=$ YES OR 2 = NO

1

1. Beryllium

2. Beryllium Oxide

3. Boron

4. Lithium Deuteride

5. Lithium Hydride

6. Magnesium

7. Polyethylene

8. Polyethylpentene

9. Silicone

10. Tantalum

11. Thorium

12. Tungsten

13. Highly Enriched Uranium

14. Natural Uranium

15. Depleted Uranium

16. Uranium-Niobium Alloy

17. Uranium-Niobium-Zirconium Allo

18. Urethane

ENTER THE NUMBER OF THE MATERIAL OF INTEREST

14

ENTER MASS OF Natural Uranium IN kg

10 
DO YOU WISH TO CHOOSE ANOTHER MATERIAL?

$1=$ YES OR $2=$ NO

1

1. Beryllium

2. Beryllium Oxide

3. Boron

4. Lithium Deuteride

5. Lithium Hydride

6. Magnesium

7. Polyethylene

8. Polyethylpentene

9. Silicone

10. Tantalum

11. Thorium

12. Tungsten

13. Highly Enriched Uranium

14. Natural Uranium

15. Depleted Uranium

16. Uranium-Niobium Alloy

17. Uranium-Niobium-Zirconium Allo

18. Urethane

ENTER THE NUMBER OF THE MATERIAL OF INTEREST

15

ENTER MASS OF Depleted Uranium IN kg

10

DO YOU WISH TO CHOOSE ANOTHER MATERIAL?

$1=$ YES OR $2=$ NO

2

C:ITSRA $>$ 


\section{Output File for Run without User-Supplied Materials}

Highly Enriched Uranium

[1.0000E+01 kg]

DIRECT RADIATION EXPOSURE:

DISTANCE FROM SOURCE $=152.40 \mathrm{~m}$

DOSE RATES:

CONTRIBUTION DUE TO U-232 $=3.2048 \mathrm{E}-07 \mathrm{rem} / \mathrm{hr}$

CONTRIBUTION DUE TO U-234 $=4.0427 \mathrm{E}-07 \mathrm{rem} / \mathrm{hr}$

CONTRIBUTION DUE TO U-235 $=1.9360 E-07 \mathrm{rem} / \mathrm{hr}$

CONTRIBUTION DUE TO U-236 $=2.1572 E-12 \mathrm{rem} / \mathrm{hr}$

CONTRIBUTION DUE TO U-238 $=1.0484 E-09 \mathrm{rem} / \mathrm{hr}$

TOTAL $=9.1941 \mathrm{E}-07 \mathrm{rem} / \mathrm{hr}$

EXPOSURE TIME $=3.00$ hours

DOSE DUE TO DIRECT RADIATION $=2.7582 E-06 \mathrm{rem}$

ATMOSPHERIC DISPERSION CALCULATIONS:

AMBIENT PROPERTIES: $\quad$ AMBIENT TEMPERATURE $=298.0 \mathrm{~K}$

MOLECULAR MEIGHT OF AMBIENT AIR $=28.96$

DENSITY OF AMBIENT AIR $=1.1614 E+00 \mathrm{~kg} / \mathrm{m3}$

WIND VELOCITY AT $2 \mathrm{~m}=1.00 \mathrm{~m} / \mathrm{s}$

PLUME PROPERTIES:

MOLECULAR UEIGHT OF PLUME $=28.96$

FLAME TEMPERATURE $=1200.0 \mathrm{~K}$

INITIAL PLUME RADIUS $=0.50 \mathrm{~m}$

BURN RATE $=8.9000 E-04 \mathrm{~kg} / \mathrm{s}$

INITIAL VERTICAL PLUME VELOCITY $=1.00 \mathrm{~m} / \mathrm{s}$

EQUILIBRIUM PLUME RISE $=3.6867 \mathrm{E}+01 \mathrm{~m}$

RECEPTOR INFORMATION: CROSSWIND DISTANCE $=0.0000 E+00 \mathrm{~m}$

ELEVATION OF RECEPTOR $=0.0000 E+00 \mathrm{~m}$

EXPOSURE TIME $=0.0000 \mathrm{E}+00 \mathrm{hr}$

BREATHING RATE $=1.20 \mathrm{~m} 3 / \mathrm{hr}$

Downwind

Stability

Concentration Concentration Inhalation

Uptake

istance

Class

*Exposure Time Dose

(m)

( $(\mathrm{mg} / \mathrm{m} 3)$

(mg-hr/m3)

(rem)

(mg)

$\begin{array}{rlllll}100.0 & \text { A } & 1.0325 E-01 & 3.2224 E-01 & 4.1055 E+00 & 3.8669 E-01 \\ 200.0 & \text { A } & 5.2527 E-02 & 1.6394 E-01 & 2.0887 E+00 & 1.9673 E-01 \\ 300.0 & \text { B } & 4.2874 E-02 & 1.3382 E-01 & 1.7049 E+00 & 1.6058 E-01 \\ 400.0 & \text { B } & 4.0805 E-02 & 1.2736 E-01 & 1.6226 E+00 & 1.5283 E-01 \\ 500.0 & \text { E } & 4.1906 E-02 & 1.3079 E-01 & 1.6664 E+00 & 1.5695 E-01 \\ 600.0 & \text { E } & 5.4997 E-02 & 1.7165 E-01 & 2.1869 E+00 & 2.0598 E-01 \\ 700.0 & \text { E } & 6.0561 E-02 & 1.8902 E-01 & 2.4082 E+00 & 2.2682 E-01 \\ 800.0 & \text { E } & 6.1264 E-02 & 1.9121 E-01 & 2.4361 E+00 & 2.2945 E-01 \\ 900.0 & \text { F } & 6.0137 E-02 & 1.8769 E-01 & 2.3913 E+00 & 2.2523 E-01 \\ 1000.0 & \text { F } & 6.4247 E-02 & 2.0052 E-01 & 2.5547 E+00 & 2.4062 E-01 \\ 1100.0 & \text { F } & 6.5887 E-02 & 2.0564 E-01 & 2.6199 E+00 & 2.4677 E-01 \\ 1200.0 & \text { F } & 6.5847 E-02 & 2.0552 E-01 & 2.6184 E+00 & 2.4662 E-01 \\ 1300.0 & \text { F } & 6.4727 E-02 & 2.0202 E-01 & 2.5738 E+00 & 2.4242 E-01 \\ 1400.0 & \text { F } & 6.2949 E-02 & 1.9647 \mathrm{E}-01 & 2.5031 E+00 & 2.3576 E-01 \\ 1500.0 & \text { F } & 6.0798 E-02 & 1.8976 E-01 & 2.4176 E+00 & 2.2771 E-01 \\ 1600.0 & \text { F } & 5.8464 E-02 & 1.8247 E-01 & 2.3248 E+00 & 2.1897 E-01 \\ 1700.0 & \text { F } & 5.6071 E-02 & 1.7500 E-01 & 2.2296 E+00 & 2.1000 E-01 \\ 1800.0 & \text { F } & 5.3695 E-02 & 1.6759 E-01 & 2.1351 E+00 & 2.0110 E-01 \\ 1900.0 & F & 5.1384 E-02 & 1.6037 E-01 & 2.0433 E+00 & 1.9245 E-01 \\ 2000.0 & \text { F } & 4.9167 E-02 & 1.5345 E-01 & 1.9551 E+00 & 1.8414 E-01\end{array}$


HORST CASE VALUES:

$\begin{array}{llllll}100.0 & A & 1.0325 E-01 & 3.2224 E-01 & 4.1055 E+00 & 3.8669 E-01\end{array}$

MAXIMUM RADIOLOGICAL CONSEQUENCES OF INHALATION:

RADIOLOGICAL DOSES:

CONTRIBUTION DUE TO U-232 $=5.9979 E+02 \mathrm{rem} / \mathrm{g}$ CONTRIBUTION DUE TO U-234 $=9.7344 \mathrm{E}+03 \mathrm{rem} / \mathrm{g}$ CONTRIBUTION DUE TO U-235 $=2.4391 \mathrm{E}+02 \mathrm{rem} / \mathrm{g}$ CONTRIBUTION DUE TO U-236 $=3.7312 E+01 \mathrm{rem} / \mathrm{g}$ CONTRIBUTION DUE TO $U-238=1.7470 E+00 \mathrm{rem} / \mathrm{g}$ TOTAL $=1.0617 \mathrm{E}+04 \mathrm{rem} / \mathrm{g}$

DOSE DUE TO INHALATION $=4.1055 E+00 \mathrm{rem}$

MAXIMUM CHEMICAL CONSEQUENCES OF INHALATION:

UPTAKE DUE TO INHALATION $=3.8669 \mathrm{E}-01 \mathrm{mg}$

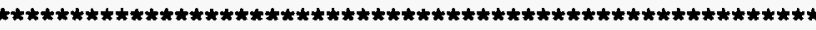

WATER TRANSPORT CALCULATIONS:

FRACTION REACHING PUBLIC DRINKING SUPPLY $=1.0000 E-02$

TANK VOLUME $=4.7317 E+02 \mathrm{m3}$

DAILY WATER UPTAKE $=2.0000 E-03 \mathrm{~m} 3$

MASS AVAILABLE FOR UPTAKE $=4.2268 \mathrm{E}-07 \mathrm{~kg}$

RADIOLOGICAL CONSEQUENCES OF INGESTION:

RADIOLOGICAL DOSES:

CONTRIBUTION DUE TO U-232 $=1.1638 E+00 \mathrm{rem} / \mathrm{g}$ CONTRIBUTION DUE TO U-234 $=1.9469 E+01 \mathrm{rem} / \mathrm{g}$ CONTRIBUTION DUE TO U-235 $=5.0814 \mathrm{E}-01 \mathrm{rem} / \mathrm{g}$ CONTRIBUTION DUE TO U-236 $=7.7734 \mathrm{E}-02 \mathrm{rem} / \mathrm{g}$ CONTRIBUTION DUE TO U-238 $=3.3485 E-03 \mathrm{rem} / \mathrm{g}$ TOTAL $=2.1222 E+01 \mathrm{rem} / \mathrm{g}$

DOSE DUE TO INGESTION $=\mathbf{8 . 9 6 9 9 E - 0 3 \mathrm { rem }}$

CHEMICAL CONSEQUENCES OF INGESTION:

INTAKE DUE TO INGESTION $=4.2268 \mathrm{E}-01 \mathrm{mg}$ 
DIRECT RADIATION EXPOSURE:

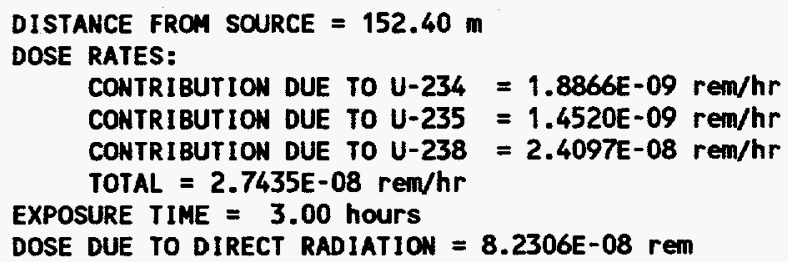

ATMOSPHERIC DISPERSION CALCULATIONS:

AMBIENT PROPERTIES: $\quad$ AMBIENT TEMPERATURE $=298.0 \mathrm{~K}$

MOLECULAR WEIGHT OF AMBIENT AIR $=\mathbf{2 8 . 9 6}$ DENSITY OF AMBIENT AIR $=1.1614 E+00 \mathrm{~kg} / \mathrm{m3}$ WIND VELOCITY AT $2 \mathrm{~m}=1.00 \mathrm{~m} / \mathrm{s}$

PLUME PROPERTIES:

MOLECULAR UEIGHT OF PLUME $=\mathbf{2 8 . 9 6}$ FLAME TEMPERATURE $=1200.0 \mathrm{~K}$ INITIAL PLUNE RADIUS $=0.50 \mathrm{~m}$ BURN RATE $=8.9000 \mathrm{E}-04 \mathrm{~kg} / \mathrm{s}$ INITIAL VERIICAL PLUME VELOCITY $=1.00 \mathrm{~m} / \mathrm{s}$ EQUILIBRIUM PLUME RISE $=3.6867 \mathrm{E}+01 \mathrm{~m}$

RECEPTOR INFORMATION: CROSSWIND DISTANCE $=0.0000 E+00 \mathrm{~m}$ ELEVATION OF RECEPTOR $=0.0000 E+00 \mathrm{~m}$ EXPOSURE TIME $=3.1211 \mathrm{E}+00 \mathrm{hr}$ BREATHING RATE $=1.20 \mathrm{~m} 3 / \mathrm{hr}$

Downwind Stability Concentration Concentration Inhalation Uptake Distance Class *Exposure Time Dose (m) ( $\mathrm{mg} / \mathrm{m} 3)$ $(\mathrm{mg}-\mathrm{hr} / \mathrm{m} 3) \quad(\mathrm{rem})$

(mg)

\begin{tabular}{|c|c|c|c|c|c|}
\hline $\begin{array}{r}100.0 \\
200.0 \\
300.0 \\
400.0 \\
500.0 \\
600.0 \\
700.0 \\
800.0 \\
900.0 \\
1000.0 \\
1100.0 \\
1200.0 \\
1300.0 \\
1400.0 \\
1500.0 \\
1600.0 \\
1700.0 \\
1800.0 \\
1900.0 \\
2000.0\end{array}$ & $\begin{array}{l}A \\
A \\
B \\
B \\
E \\
E \\
E \\
E \\
F \\
F \\
F \\
F \\
F \\
F \\
F \\
F \\
F \\
F \\
F \\
F\end{array}$ & $\begin{array}{l}1.0325 E-01 \\
5.2527 E-02 \\
4.2874 E-02 \\
4.0805 E-02 \\
4.1906 E-02 \\
5.4997 E-02 \\
6.0561 E-02 \\
6.1264 E-02 \\
6.0137 E-02 \\
6.4247 E-02 \\
6.5887 E-02 \\
6.5847 E-02 \\
6.4727 E-02 \\
6.2949 E-02 \\
6.0798 E-02 \\
5.8464 E-02 \\
5.6071 E-02 \\
5.3695 E-02 \\
5.1384 E-02 \\
4.9167 E-02\end{array}$ & $\begin{array}{l}3.2224 E-01 \\
1.6394 E-01 \\
1.3382 E-01 \\
1.2736 E-01 \\
1.3079 E-01 \\
1.7165 E-01 \\
1.8902 E-01 \\
1.9121 E-01 \\
1.8769 E-01 \\
2.0052 E-01 \\
2.0564 E-01 \\
2.0552 E-01 \\
2.0202 E-01 \\
1.9647 E-01 \\
1.8976 E-01 \\
1.8247 E-01 \\
1.7500 E-01 \\
1.6759 E-01 \\
1.6037 E-01 \\
1.5345 E-01\end{array}$ & $\begin{array}{l}3.3800 E-02 \\
1.7196 E-02 \\
1.4036 E-02 \\
1.3358 E-02 \\
1.3719 E-02 \\
1.8005 E-02 \\
1.9826 E-02 \\
2.0056 E-02 \\
1.9687 E-02 \\
2.1033 E-02 \\
2.1570 E-02 \\
2.1557 E-02 \\
2.1190 E-02 \\
2.0608 E-02 \\
1.9904 E-02 \\
1.9140 E-02 \\
1.8356 E-02 \\
1.7578 E-02 \\
1.6822 E-02 \\
1.6096 E-02\end{array}$ & $\begin{array}{l}3.8669 E-01 \\
1.9673 E-01 \\
1.6058 E-01 \\
1.5283 E-01 \\
1.5695 E-01 \\
2.0598 E-01 \\
2.2682 E-01 \\
2.2945 E-01 \\
2.2523 E-01 \\
2.4062 E-01 \\
2.4677 E-01 \\
2.4662 E-01 \\
2.4242 E-01 \\
2.3576 E-01 \\
2.2771 E-01 \\
2.1897 E-01 \\
2.1000 E-01 \\
2.0110 E-01 \\
1.9245 E-01 \\
1.8414 E-01\end{array}$ \\
\hline \multicolumn{6}{|c|}{ WORST CASE VALUES: } \\
\hline 100.0 & A & $1.0325 \mathrm{E}-01$ & $3.2224 E-01$ & $3.3800 E-02$ & $3.8669 \mathrm{E}-01$ \\
\hline
\end{tabular}

MAXIMUM RADIOLOGICAL CONSEQUENCES OF INHALATION: 
RADIOLOGICAL DOSES:

CONTRIBUTION DUE TO U-234 $=4.5427 \mathrm{E}+01 \mathrm{rem} / \mathrm{g}$

CONTRIBUT ION DUE TO $U-235=1.8293 E+00 \mathrm{rem} / \mathrm{g}$

CONTRIBUTION DUE TO U-238 $=4.0153 E+01 \mathrm{rem} / 9$

TOTAL = 8.7409E+01 rem/g

DOSE DUE TO INHALATION $=3.3800 E-02$ rem

MAXIMUM CHEMICAL CONSEQUENCES OF INHALATION:

UPTAKE DUE TO INHALATION $=3.8669 \mathrm{E}-01 \mathrm{mg}$

WATER TRANSPORT CALCULATIONS:

FRACTION REACHING PUBLIC DRINKING SUPPLY $=1.0000 E-02$

TANK VOLUME $=4.7317 \mathrm{E}+02 \mathrm{m3}$

DAILY WATER UPTAKE $=2.0000 E-03 \mathrm{m3}$

MASS AVAILABLE FOR UPTAKE $=4.2268 \mathrm{E}-07 \mathrm{~kg}$

RADIOLOGICAL CONSEQUENCES OF INGESTION:

RADIOLOGICAL DOSES:

CONTRIBUTION DUE TO U-234 $=9.0854 E-02 \mathrm{rem} / \mathrm{g}$

CONTRIBUTION DUE TO U-235 $=3.8111 \mathrm{E}-03 \mathrm{rem} / \mathrm{g}$

CONTRIBUTION DUE TO U-238 $=7.6960 \mathrm{E}-02 \mathrm{rem} / \mathrm{g}$

TOTAL $=1.7163 \mathrm{E}-01 \mathrm{rem} / \mathrm{g}$

DOSE DUE TO INGESTION $=7.2542 \mathrm{E}-05 \mathrm{rem}$

CHEMICAL CONSEQUENCES OF INGESTION:

INTAKE DUE TO INGESTION $=4.2268 \mathrm{E}-01 \mathrm{mg}$ 
DIRECT RADIATION EXPOSURE:

DISTANCE FROM SOURCE $=152.40 \mathrm{~m}$

DOSE RATES:

CONTRIBUTION DUE TO U-235 $=4.0162 \mathrm{E}-10 \mathrm{rem} / \mathrm{hr}$

CONTRIBUTION DUE TO U-238 $=2.4222 E-08 \mathrm{rem} / \mathrm{hr}$

TOTAL $=2.4624 \mathrm{E}-08 \mathrm{rem} / \mathrm{hr}$

EXPOSURE TIME $=3.00$ hours

DOSE DUE TO DIRECT RADIATION $=7.3871 E-08$ rem

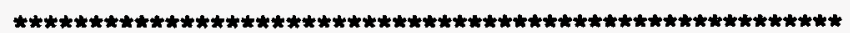

ATMOSPHERIC DISPERSION CALCULATIONS:

AMBIENT PROPERTIES: $\quad$ AMBIENT TEMPERATURE $=298.0 \mathrm{~K}$

MOLECULAR WEIGHT OF AMBIENT AIR $=28.96$

DENSITY OF AMBIENT AIR $=1.1614 \mathrm{E}+00 \mathrm{~kg} / \mathrm{m3}$

WIND VELOCITY AT $2 \mathrm{~m}=1.00 \mathrm{~m} / \mathrm{s}$

PLUME PROPERTIES:

MOLECULAR WEIGHT OF PLUME $=28.96$

FLAME TEMPERATURE $=1200.0 \mathrm{~K}$

INITIAL PLUME RADIUS $=0.50 \mathrm{~m}$

BURN RATE $=8.9000 E-04 \mathrm{~kg} / \mathrm{s}$

INITIAL VERTICAL PLUME VELOCITY $=1.00 \mathrm{~m} / \mathrm{s}$

EQUILIBRIUM PLUME RISE $=3.6867 \mathrm{E}+01 \mathrm{~m}$

RECEPTOR INFORMATION: CROSSWIND DISTANCE $=0.0000 E+00 \mathrm{~m}$

ELEVATION OF RECEPTOR $=0.0000 E+00 \mathrm{~m}$

EXPOSURE TIME $=3.1211 \mathrm{E}+00 \mathrm{hr}$

BREATHING RATE $=1.20 \mathrm{~m} 3 / \mathrm{hr}$

$\begin{array}{cccccc}\begin{array}{c}\text { Downwind } \\ \text { Distance } \\ \text { (m) }\end{array} & \begin{array}{c}\text { Stability } \\ \text { Class }\end{array} & \begin{array}{c}\text { Concentration Concentration Inhalation } \\ \text { *Exposure Time } \\ \text { (mg-hr/m3) }\end{array} & \begin{array}{c}\text { Dose } \\ (\text { rem) }\end{array} & \text { (mg) }\end{array}$

\begin{tabular}{|c|c|c|c|c|c|}
\hline $\begin{array}{r}100.0 \\
200.0 \\
300.0 \\
400.0 \\
500.0 \\
600.0 \\
700.0 \\
800.0 \\
900.0 \\
1000.0 \\
1100.0 \\
1200.0 \\
1300.0 \\
1400.0 \\
1500.0 \\
1600.0 \\
1700.0 \\
1800.0 \\
1900.0 \\
2000.0\end{array}$ & $\begin{array}{l}A \\
A \\
B \\
B \\
E \\
E \\
E \\
E \\
F \\
F \\
F \\
F \\
F \\
F \\
F \\
F \\
F \\
F \\
F \\
F\end{array}$ & $\begin{array}{l}1.0325 E-01 \\
5.2527 E-02 \\
4.2874 E-02 \\
4.0805 E-02 \\
4.1906 E-02 \\
5.4997 E-02 \\
6.0561 E-02 \\
6.1264 E-02 \\
6.0137 E-02 \\
6.4247 E-02 \\
6.5887 E-02 \\
6.5847 E-02 \\
6.4727 E-02 \\
6.2949 E-02 \\
6.0798 E-02 \\
5.8464 E-02 \\
5.6071 E-02 \\
5.3695 E-02 \\
5.1384 E-02 \\
4.9167 E-02\end{array}$ & $\begin{array}{l}3.2224 E-01 \\
1.6394 E-01 \\
1.3382 E-01 \\
1.2736 E-01 \\
1.3079 E-01 \\
1.7165 E-01 \\
1.8902 E-01 \\
1.9121 E-01 \\
1.8769 E-01 \\
2.0052 E-01 \\
2.0564 E-01 \\
2.0552 E-01 \\
2.0202 E-01 \\
1.9647 E-01 \\
1.8976 E-01 \\
1.8247 E-01 \\
1.7500 E-01 \\
1.6759 E-01 \\
1.6037 E-01 \\
1.5345 E-01\end{array}$ & $\begin{array}{l}1.5803 E-02 \\
8.0400 E-03 \\
6.5625 E-03 \\
6.2457 E-03 \\
6.4143 E-03 \\
8.4179 E-03 \\
9.2696 E-03 \\
9.3772 E-03 \\
9.2047 E-03 \\
9.8338 E-03 \\
1.0085 E-02 \\
1.0079 E-02 \\
9.9073 E-03 \\
9.6351 E-03 \\
9.3059 E-03 \\
8.9487 E-03 \\
8.5823 E-03 \\
8.2186 E-03 \\
7.8650 E-03 \\
7.5256 E-03\end{array}$ & $\begin{array}{l}3.8669 \mathrm{E}-01 \\
1.9673 \mathrm{E}-01 \\
1.6058 \mathrm{E}-01 \\
1.5283 \mathrm{E}-01 \\
1.5695 \mathrm{E}-01 \\
2.0598 \mathrm{E}-01 \\
2.2682 \mathrm{E}-01 \\
2.2945 \mathrm{E}-01 \\
2.2523 \mathrm{E}-01 \\
2.4062 \mathrm{E}-01 \\
2.4677 \mathrm{E}-01 \\
2.4662 \mathrm{E}-01 \\
2.4242 \mathrm{E}-01 \\
2.3576 \mathrm{E}-01 \\
2.2771 \mathrm{E}-01 \\
2.1897 \mathrm{E}-01 \\
2.1000 \mathrm{E}-01 \\
2.0110 \mathrm{E}-01 \\
1.9245 \mathrm{E}-01 \\
1.8414 \mathrm{E}-01\end{array}$ \\
\hline
\end{tabular}

WORST CASE VALUES:

100.0 A $\quad 1.0325 E-01 \quad 3.2224 E-01 \quad 1.5803 E-02 \quad 3.8669 E-01$

MAXIMUM RADIOLOGICAL CONSEQUENCES OF INHALATION:

RADIOLOGICAL DOSES: 
CONTRIBUTION DUE TO $U-235=5.0598 E-01 \mathrm{rem} / \mathrm{g}$

CONTRIBUTION DUE TO U-238 $=4.0362 E+01 \mathrm{rem} / \mathrm{g}$

TOTAL $=4.0868 \mathrm{E}+01 \mathrm{rem} / \mathrm{g}$

DOSE DUE TO INHALATION $=1.5803 E-02 \mathrm{rem}$

MAXIMUM CHEMICAL CONSEQUENCES OF INHALATION:

UPTAKE DUE TO INHALATION $=3.8669 \mathrm{E}-01 \mathrm{mg}$

WATER TRANSPORT CALCULATIONS:

FRACTION REACHING PUBLIC DRINKING SUPPLY $=1.0000 E-02$

TANK VOLUME $=4.7317 \mathrm{E}+02 \mathrm{m3}$

DAILY WATER UPTAKE $=2.0000 E-03 \mathrm{~m} 3$

MASS AVAILABLE FOR UPTAKE $=4.2268 \mathrm{E}-07 \mathrm{~kg}$

RADIOLOGICAL CONSEQUENCES OF INGESTION:

RADIOLOGICAL DOSES:

CONTRIBUTION DUE TO U-235 $=1.0541 \mathrm{E}-03 \mathrm{rem} / \mathrm{g}$

CONTRIBUTION DUE TO U-238 $=7.7360 \mathrm{E}-02 \mathrm{rem} / \mathrm{g}$

TOTAL $=7.8414 \mathrm{E}-02 \mathrm{rem} / \mathrm{g}$

DOSE DUE TO INGESTION $=3.3144 E-05$ rem

CHEMICAL CONSEQUENCES OF INGESTION:

INTAKE DUE TO INGESTION $=4.2268 E-01 \mathrm{mg}$ 
TOTAL RADIOLOGICAL DOSES FOR SHIPMENT:

TOTAL RADIOLOGICAL DOSE DUE TO DIRECT RADIATION $=2.9144 \mathrm{E}-06 \mathrm{rem}$

TOTAL RADIOLOGICAL DOSE DUE TO INHALATION $=4.1551 E+00 \mathrm{rem}$

TOTAL RADIOLOGICAL DOSE DUE TO INGESTION $=9.0756 \mathrm{E}-03 \mathrm{rem}$ 
Screen Dump for Run with User-Supplied Materials

\section{C:ITSRAITSRA}

32-bit Power for Lahey Computer Systems Phar Lap's 386|DOS-Extender(tm) Version 5.1 Copyright (C) 1986-93 Phar Lap Software, Ince Available Memory $=14580 \mathrm{~Kb}$

ENTER THE NAME (UP TO 8 CHARACTERS) OF THE OUTPUT FILE. DO NOT PROVIDE AN EXTENSION. THE FILE WILL AUTOMATICALLY BE GIVEN THE EXTENSION .OUT

ENTER A 0 IF YOU WISH TO ACCEPT THE DEFAULT OUTPUT

O

DEFAULT VALUES ASSUMED BY PROGRAM:

1. DISTANCE FROM THE SOURCE $=152.40 \mathrm{~m}$

2. EXPOSURE TIME FOR DIRECT RADIATION $=3.00 \mathrm{hr}$

3. MINIMUM DOWNWIND DISTANCE $=100.0 \mathrm{~m}$

4. MAXIMUM DOWNWIND DISTANCE $=2000.0 \mathrm{~m}$

5. DOWNWIND DISTANCE INCREMENT $=100.0 \mathrm{~m}$

6. ELEVATION $=0.0 \mathrm{~m}$

7. AMBIENT TEMPERATURE $=298.00 \mathrm{~K}$

8. INITIAL PLUME RADIUS $=0.50 \mathrm{~m}$

9. WIND VELOCITY AT AN ELEVATION OF $2 \mathrm{~m}=1.00 \mathrm{~m} / \mathrm{s}$

10. BREATHING RATE $=1.20 \mathrm{~m} 3 / \mathrm{hr}$

11. EXPOSURE TIME FOR INHALATION $=$ BURN DURATION

12. VOLUME OF THE WATER TANK $=473.17 \mathrm{~m} 3$

13. INDIVIDUAL DAILY UPTAKE OF WATER $=0.0020 \mathrm{~m} 3$

DO YOU WISH TO CHANGE ANY OF THESE VALUES?

$1=$ YES OR 2 = NO

2

DO YOU WISH TO ANALYZE MATERIALS OTHER THAN THOSE

CURRENTLY IN THE DATABASE?

$1=$ YES, $2=\mathrm{NO}$

1

ADDITIONAL MATERIALS SHOULD BE DEFINED IN FILE TSRA.DAT

1. Beryllium

2. Beryllium Oxide

3. Boron 
4. Lithium Deuteride

5. Lithium Hydride

6. Magnesium

7. Polyethylene

8. Polyethylpentene

9. Silicone

10. Tantalum

11. Thorium

12. Tungsten

13. Highly Enriched Uranium

14. Natural Uranium

15. Depleted Uranium

16. Uranium-Niobium Alloy

17. Uranium-Niobium-Zirconium Allo

18. Urethane

19. HE U

20. N U

21. DU

ENTER THE NUMBER OF THE MATERIAL OF INTEREST

19

ENTER MASS OF H EUIN kg

10

DO YOU WISH TO CHOOSE ANOTHER MATERIAL?

$1=$ YES OR $2=\mathrm{NO}$

1

1. Beryllium

2. Beryllium Oxide

3. Boron

4. Lithium Deuteride

5. Lithium Hydride

6. Magnesium

7. Polyethylene

8. Polyethylpentene

9. Silicone

10. Tantalum

11. Thorium

12. Tungsten

13. Highly Enriched Uranium

14. Natural Uranium

15. Depleted Uranium

16. Uranium-Niobium Alloy

17. Uranium-Niobium-Zirconium Allo

18. Urethane

19. HEU 
20. N U

21. DU

ENTER THE NUMBER OF THE MATERIAL OF INTEREST

20

ENTER MASS OF $\mathrm{N} \mathrm{U} \mathrm{IN} \mathrm{kg}$

10

DO YOU WISH TO CHOOSE ANOTHER MATERIAL?

$1=$ YES OR $2=\mathrm{NO}$

1

1. Beryllium

2. Beryllium Oxide

3. Boron

4. Lithium Deuteride

5. Lithium Hydride

6. Magnesium

7. Polyethylene

8. Polyethylpentene

9. Silicone

10. Tantalum

11. Thorium

12. Tungsten

13. Highly Enriched Uranium

14. Natural Uranium

15. Depleted Uranium

16. Uranium-Niobium Alloy

17. Uranium-Niobium-Zirconium Allo

18. Urethane

19. HEU

20. N U

21. DU

ENTER THE NUMBER OF THE MATERIAL OF INTEREST

21

ENTER MASS OF D U IN kg

10

DO YOU WISH TO CHOOSE ANOTHER MATERIAL?

$1=\mathrm{YES}$ OR $2=\mathrm{NO}$

2

C:ITSRA 


\section{TSRA.DAT (User-Supplied Material File)}

19, 'F E U', 5

$28.964,8.90-03,1200,0.01$

$\mathrm{U}-232,4.0 \mathrm{D}-08$

$232.032,72,19.0,6.7008,1.3006$

1,0

$17.84157,133.6308,1050.339,3644.77,14408.46,4.67012$

$4621940,4.48010,4.88011,1.54 D 11,7.31 D 11,2.13 D 12$

$6.17012,3.6011,7.36012,7.58011,6.93012,5.66012$

$\mathrm{U}-234,0.012$

$234.041,2.45005,18.6,1.3008,2.6005$

1,0

$1.00110-03,7.31140-03,5.65930-02,1.9480 D-01,2.7678001,1.1820002$

$7.1351 \mathrm{DO} 3,1.8679004,1.1191 \mathrm{DO} 4,2.2034 \mathrm{DO} 4,5.0551 \mathrm{D} 03,4.2723 \mathrm{DO} 4$

$5.5443003,3.3934004,2.8801004,1.3923006,3.6286006,1.9378008$

$\mathrm{U}-235,0.94$

$235.044,7.04008,18.7,1.2008,2.5005$

1,0

$6.5349 D-06,3.1690 D-05,1.6833 D-04,4.3831 D-04,1.36480-03,1.5844 D-03$

$2.8297 \mathrm{D}-03,4.8525 \mathrm{D}-03,3.4272 \mathrm{D}-05,2.8456 \mathrm{D} 00,6.8704 \mathrm{D} 01,3.9091 \mathrm{D} 01$

$3.2702 D 02,3.0189003,7.1816004,1.3098006,3.0265005,5.2699005$

$\mathrm{U}-236,0.0048$

$236.0455,2.34007,19.0,1.2008,2.5005$

1,0

9.70-05,4.840-04,2.6740-03,7.2320-03,2.34270-02,5.7870-02

$5.13 D-02,9.1312 D-02,1.3560-02,2.07746 D-01,6.2183 D-02,4.783060-01$

$4.8708 \mathrm{D}-02,1.7832 \mathrm{D}-02,7.12861 \mathrm{D}-01,6494.58,5.2117 \mathrm{D}-02,6.6527 \mathrm{D}-02$

$\mathrm{U}-238,0.04319996$

$238.051,4.47009,19.0,1.2008,2.3005$

1,0

$1.92420-04,9.0632 D-04,4.62030-03,1.15130-02,3.41060-02,3.79640-02$

$4.06480-01,1.5960002,1.6121002,9.7173002,1.7671003,2.3534003$

$3.2313003,4.7435003,6.6384003,2.0040 D 04,5.2775004,9.716 D 04$

$20,1 \mathrm{~N} \cup \cdot, 3$

$28.964,8.90-03,1200 ., 0.01$

$\mathrm{U}-234,5.6 \mathrm{D}-05$

$234.041,2.45005,18.6,1.3008,2.6005$

1,0

$1.0011 D-03,7.3114 D-03,5.65930-02,1.9480 D-01,2.7678001,1.1820002$

$7.1351003,1.8679004,1.1191004,2.2034004,5.0551003,4.2723004$

$5.5443 \mathrm{D} 03,3.3934 \mathrm{D} 04,2.8801004,1.3923 \mathrm{D} 06,3.6286 \mathrm{D} 06,1.9378 \mathrm{D} 08$

$\mathrm{U}-235,0.00705$

$235.044,7.04008,18.7,1.2008,2.5005$

1,0

$6.53490-06,3.1690 D-05,1.6833 D-04,4.3831 D-04,1.3648 D-03,1.5844 D-03$

$2.82970-03,4.8525 D-03,3.4272 D-05,2.8456000,6.8704 D 01,3.9091 D 01$

$3.2702 \mathrm{DO} 2,3.0189 \mathrm{D} 03,7.1816004,1.3098 \mathrm{D} 06,3.0265005,5.2699005$

U-238, 0.992894

$238.051,4.47009,19.0,1.2008,2.3005$

1,0

$1.9242 \mathrm{D}-04,9.0632 \mathrm{D}-04,4.6203 \mathrm{D}-03,1.1513 \mathrm{D}-02,3.4106 \mathrm{D}-02,3.7964 \mathrm{D}-02$

$4.06480-01,1.5960 D 02,1.6121002,9.7173002,1.7671003,2.3534003$

$3.2313003,4.7435003,6.6384003,2.0040004,5.2775004,9.716004$

$21,10 \mathrm{U} \cdot, 3$

$28.964,8.90-03,1200 ., 0.01$

$U-235,0.00195$

$235.044,7.04008,18.7,1.2008,2.5005$

1,0

$6.53490-06,3.16900-05,1.68330-04,4.38310-04,1.36480-03,1.58440-03$

$2.8297 \mathrm{D}-03,4.8525 \mathrm{D}-03,3.4272 \mathrm{D}-05,2.8456000,6.8704 \mathrm{D} 01,3.9091 \mathrm{D} 01$

$3.2702002,3.0189003,7.1816004,1.3098006,3.0265005,5.2699005$ 
$U-238,0.99805$

$238.051,4.47009,19.0,1.2008,2.3005$

1,0

$1.92420-04,9.06320-04,4.6203 D-03,1.1513 D-02,3.41060-02,3.7964 D-02$

4.06480-01, 1.5960002,1.6121002,9.7173002,1.7671003,2.3534003

$3.2313003,4.7435003,6.6384003,2.0040004,5.2775004,9.716004$

0, 'end of file', 0 


\section{Output File for Run with User-Supplied Materials}

ECHO OF USER-SUPPLIED MATERIAL DATA:

19 HE U

5

$2.8964 E+01 \quad 8.9000 E-03 \quad 1.2000 E+03 \quad 1.0000 E-02$

U-232 4.0000E-08

$2.3204 E+02 \quad 6.8900 E+01 \quad 1.8570 E+01 \quad 6.7000 E+08 \quad 1.3000 E+06$

$10.0000 E+00$

$\begin{array}{llllll}1.7440 E+01 & 1.3060 E+02 & 1.0270 E+03 & 3.5620 E+03 & 1.4080 E+04 & 4.5630 E+12\end{array}$

$\begin{array}{llllll}4.5170 E+06 & 4.3780 E+10 & 4.7700 E+11 & 1.5020 E+11 & 7.1490 E+11 & 2.0800 E+12\end{array}$

$\begin{array}{llllll}6.0260 E+12 & 3.5180 E+11 & 7.1910 E+12 & 7.4050 E+11 & 6.7710 E+12 & 5.5330 E+12\end{array}$

$\mathrm{U}-234 \quad 1.2000 \mathrm{E}-02$

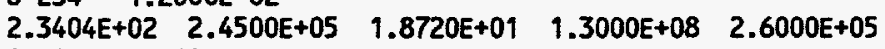

$10.0000 E+00$

$\begin{array}{llllll}1.0080 E-03 & 7.3590 E-03 & 5.6960 E-02 & 1.9610 E-01 & 2.7860 E+01 & 1.1900 E+02\end{array}$

$\begin{array}{llllll}7.1810 E+03 & 1.8800 E+04 & 1.1260 E+04 & 2.2180 E+04 & 5.0880 E+03 & 4.3000 E+04\end{array}$

$\begin{array}{llllll}5.5800 E+03 & 3.4150 E+04 & 2.8990 E+04 & 1.4010 E+06 & 3.6520 E+06 & 1.9500 E+08\end{array}$

U-235 9.4000E-01

$\begin{array}{lllll}2.3504 E+02 & 7.0400 E+08 & 1.8810 E+01 & 1.2000 E+08 & 2.5000 E+05\end{array}$

$10.0000 E+00$

$\begin{array}{lllllll}6.5730 E-06 & 3.1880 E-05 & 1.6930 E-04 & 4.4090 E-04 & 1.3730 E-03 & 1.5940 E-03\end{array}$

$\begin{array}{llllll}2.8460 E-03 & 4.8810 E-03 & 3.4470 E-05 & 2.8620 E+00 & 6.9110 E+01 & 3.9320 E+01\end{array}$

$\begin{array}{llllll}3.2890 E+02 & 3.0370 E+03 & 7.2240 E+04 & 1.3180 E+06 & 3.0440 E+05 & 5.3010 E+05\end{array}$

U-236 4.8000E-03

$2.3605 E+02 \quad 2.3400 E+07 \quad 1.8890 E+01 \quad 1.2000 E+08 \quad 2.5000 E+05$

$10.0000 E+00$

$\begin{array}{lllllll}9.6420 E-05 & 4.8150 E-04 & 2.6580 E-03 & 7.1900 E-03 & 2.3290 E-02 & 5.7540 E-02\end{array}$

$\begin{array}{llllll}5.1000 E-02 & 9.0780 E-02 & 1.3480 E-02 & 2.0650 E-01 & 6.1820 E-02 & 4.7550 E-01\end{array}$

$\begin{array}{llllll}4.8430 E-02 & 1.7730 E-02 & 7.0870 E-01 & 6.4570 E+03 & 5.1820 E-02 & 6.6140 E-02\end{array}$

$\mathrm{U}-238 \quad 4.3200 \mathrm{E}-02$

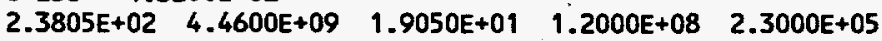

$10.0000 E+00$

$\begin{array}{llllll}1.9290 E-04 & 9.0870 E-04 & 4.6320 E-03 & 1.1540 E-02 & 3.4200 E-02 & 3.8060 E-02\end{array}$

$\begin{array}{llllll}4.0750 E-01 & 1.6000 E+02 & 1.6160 E+02 & 9.7430 E+02 & 1.7720 E+03 & 2.3600 E+03\end{array}$

$\begin{array}{lllllll}3.2400 E+03 & 4.7560 E+03 & 6.6560 E+03 & 2.0090 E+04 & 5.2910 E+04 & 9.7420 E+04\end{array}$

$20 \mathrm{~N} \mathrm{U}$

$2.8964 E+01 \quad 8.9000 E-03 \quad 1.2000 E+03 \quad 1.0000 E-02$

U-234 5.6000E-05

$2.3404 E+02 \quad 2.4500 E+05 \quad 1.8720 E+01 \quad 1.3000 E+08 \quad 2.6000 E+05$

$10.0000 E+00$

$\begin{array}{llllll}1.0080 E-03 & 7.3590 E-03 & 5.6960 E-02 & 1.9610 E-01 & 2.7860 E+01 & 1.1900 E+02\end{array}$

$\begin{array}{llllll}7.1810 E+03 & 1.8800 E+04 & 1.1260 E+04 & 2.2180 E+04 & 5.0880 E+03 & 4.3000 E+04\end{array}$

$\begin{array}{llllll}5.5800 E+03 & 3.4150 E+04 & 2.8990 E+04 & 1.4010 E+06 & 3.6520 E+06 & 1.9500 E+08\end{array}$

U-235 7.0500E-03

$2.3504 E+02 \quad 7.0400 E+08 \quad 1.8810 E+01 \quad 1.2000 E+08 \quad 2.5000 E+05$

$10.0000 E+00$

6.5730E-06 $3.1880 E-05 \quad 1.6930 E-04 \quad 4.4090 E-04 \quad 1.3730 E-03 \quad 1.5940 E-03$

$2.8460 E-03 \quad 4.8810 E-03 \quad 3.4470 E-05 \quad 2.8620 E+00 \quad 6.9110 E+01 \quad 3.9320 E+01$

$\begin{array}{llllll}3.2890 E+02 & 3.0370 E+03 & 7.2240 E+04 & 1.3180 E+06 & 3.0440 E+05 & 5.3010 E+05\end{array}$

U-238 $9.9289 E-01$

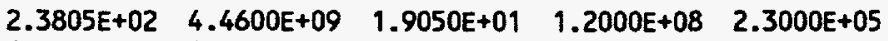

$10.0000 E+00$

$\begin{array}{lllllll}1.9290 E-04 & 9.0870 E-04 & 4.6320 E-03 & 1.1540 E-02 & 3.4200 E-02 & 3.8060 E-02\end{array}$

$\begin{array}{llllll}4.0750 E-01 & 1.6000 E+02 & 1.6160 E+02 & 9.7430 E+02 & 1.7720 E+03 & 2.3600 E+03\end{array}$

$\begin{array}{llllll}3.2400 E+03 \quad 4.7560 E+03 & 6.6560 E+03 & 2.0090 E+04 & 5.2910 E+04 & 9.7420 E+04\end{array}$

$21 \mathrm{DU}$

2

$2.8964 E+01 \quad 8.9000 E-03 \quad 1.2000 E+03 \quad 1.0000 E-02$

$U-235 \quad 1.9500 E-03$

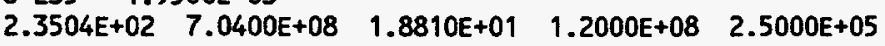

$10.0000 E+00$

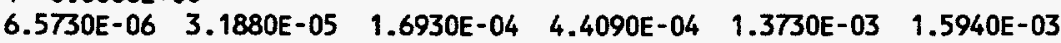


$\begin{array}{llllll}2.8460 E-03 & 4.8810 E-03 & 3.4470 E-05 & 2.8620 E+00 & 6.9110 E+01 & 3.9320 E+01\end{array}$

$\begin{array}{llllll}3.2890 E+02 & 3.0370 E+03 & 7.2240 E+04 & 1.3180 E+06 & 3.0440 E+05 & 5.3010 E+05\end{array}$

$\mathrm{U}-238 \quad 9.9805 \mathrm{E}-01$

$\begin{array}{lllll}2.3805 E+02 & 4.4600 E+09 & 1.9050 E+01 & 1.2000 E+08 & 2.3000 E+05\end{array}$

$10: 0000 E+00$

$\begin{array}{llllll}1.9290 E-04 & 9.0870 E-04 & 4.6320 E-03 & 1.1540 E-02 & 3.4200 E-02 & 3.8060 E-02\end{array}$

$\begin{array}{llllll}4.0750 E-01 & 1.6000 E+02 & 1.6160 E+02 & 9.7430 E+02 & 1.7720 E+03 & 2.3600 E+03\end{array}$

$\begin{array}{llllll}3.2400 E+03 & 4.7560 E+03 & 6.6560 E+03 & 2.0090 E+04 & 5.2910 E+04 & 9.7420 E+04\end{array}$ 
DIRECT RADIATION EXPOSURE:

DISTANCE FROM SOURCE $=152.40 \mathrm{~m}$

DOSE RATES:

CONTRIBUTION DUE TO U-232 $=3.2048 \mathrm{E}-07 \mathrm{rem} / \mathrm{hr}$

CONTRIBUTION DUE TO U-234 $=4.0427 \mathrm{E}-07 \mathrm{rem} / \mathrm{hr}$

CONTRIBUTION DUE TO U-235 $=1.9360 E-07 \mathrm{rem} / \mathrm{hr}$

CONTRIBUTION DUE TO U-236 $=2.1572 E-12 \mathrm{rem} / \mathrm{hr}$

CONTRIBUTION DUE TO U-238 $=1.0484 \mathrm{E}-09 \mathrm{rem} / \mathrm{hr}$

TOTAL $=9.1941 \mathrm{E}-07 \mathrm{rem} / \mathrm{hr}$

EXPOSURE TIME $=3.00$ hours

DOSE DUE TO DIRECT RADIATION $=2.7582 E-06 \mathrm{rem}$

ATMOSPHERIC DISPERSION CALCULATIONS:

AMBIENT PROPERTIES: $\quad$ AMBIENT TEMPERATURE $=298.0 \mathrm{~K}$

MOLECULAR UEIGHT OF AMBIENT AIR $=28.96$ DENSITY OF AMBIENT AIR $=1.1614 \mathrm{E}+00 \mathrm{~kg} / \mathrm{m} 3$ HIND VELOCITY AT $2 \mathrm{~m}=1.00 \mathrm{~m} / \mathrm{s}$

PLUME PROPERTIES:

MOLECULAR NEIGHT OF PLUME $=28.96$

FLAME TEMPERATURE $=1200.0 \mathrm{~K}$

INITIAL PLUME RADIUS $=0.50 \mathrm{~m}$

BURN RATE $=8.9000 E-04 \mathrm{~kg} / \mathrm{s}$

INITIAL VERTICAL PLUME VELOCITY $=1.00 \mathrm{~m} / \mathrm{s}$

EQUILIBRIUM PLUME RISE $=3.6867 E+01 \mathrm{~m}$

RECEPTOR INFORMATION: CROSSUIND DISTANCE $=0.0000 E+00 \mathrm{~m}$

ELEVATION OF RECEPTOR $=0.0000 E+00 \mathrm{~m}$

EXPOSURE TIME $=0.0000 E+00 \mathrm{hr}$

BREATHING RATE $=1.20 \mathrm{~m} 3 / \mathrm{hr}$

Downwind Stability Concentration Concentration Inhalation Uptake
Distance Class

(m) (mg/m3) (mg-hr/m3) (rem) (mg)

\begin{tabular}{rlllll}
\hline & & & & & \\
100.0 & A & $1.0325 E-01$ & $3.2224 E-01$ & $4.1055 E+00$ & $3.8669 E-01$ \\
200.0 & A & $5.2527 \mathrm{E}-02$ & $1.6394 \mathrm{E}-01$ & $2.0887 \mathrm{E}+00$ & $1.9673 \mathrm{E}-01$ \\
300.0 & B & $4.2874 \mathrm{E}-02$ & $1.3382 \mathrm{E}-01$ & $1.7049 \mathrm{E}+00$ & $1.6058 \mathrm{E}-01$ \\
400.0 & B & $4.0805 \mathrm{E}-02$ & $1.2736 \mathrm{E}-01$ & $1.6226 \mathrm{E}+00$ & $1.5283 \mathrm{E}-01$ \\
500.0 & E & $4.1906 \mathrm{E}-02$ & $1.3079 \mathrm{E}-01$ & $1.6664 \mathrm{E}+00$ & $1.5695 \mathrm{E}-01$ \\
600.0 & E & $5.4997 \mathrm{E}-02$ & $1.7165 \mathrm{E}-01$ & $2.1869 \mathrm{E}+00$ & $2.0598 \mathrm{E}-01$ \\
700.0 & E & $6.0561 \mathrm{E}-02$ & $1.8902 \mathrm{E}-01$ & $2.4082 \mathrm{E}+00$ & $2.2682 \mathrm{E}-01$ \\
800.0 & E & $6.1264 \mathrm{E}-02$ & $1.9121 \mathrm{E}-01$ & $2.4361 \mathrm{E}+00$ & $2.2945 \mathrm{E}-01$ \\
900.0 & F & $6.0137 \mathrm{E}-02$ & $1.8769 \mathrm{E}-01$ & $2.3913 \mathrm{E}+00$ & $2.2523 \mathrm{E}-01$ \\
1000.0 & F & $6.4247 \mathrm{E}-02$ & $2.0052 \mathrm{E}-01$ & $2.5547 \mathrm{E}+00$ & $2.4062 \mathrm{E}-01$ \\
1100.0 & F & $6.5887 \mathrm{E}-02$ & $2.0564 \mathrm{E}-01$ & $2.6199 \mathrm{E}+00$ & $2.4677 \mathrm{E}-01$ \\
1200.0 & F & $6.5847 \mathrm{E}-02$ & $2.0552 \mathrm{E}-01$ & $2.6184 \mathrm{E}+00$ & $2.4662 \mathrm{E}-01$ \\
1300.0 & F & $6.4727 \mathrm{E}-02$ & $2.0202 \mathrm{E}-01$ & $2.5738 \mathrm{E}+00$ & $2.4242 \mathrm{E}-01$ \\
1400.0 & F & $6.2949 \mathrm{E}-02$ & $1.9647 \mathrm{E}-01$ & $2.5031 \mathrm{E}+00$ & $2.3576 \mathrm{E}-01$ \\
1500.0 & F & $6.0798 \mathrm{E}-02$ & $1.8976 \mathrm{E}-01$ & $2.4176 \mathrm{E}+00$ & $2.2771 \mathrm{E}-01$ \\
1600.0 & F & $5.8464 \mathrm{E}-02$ & $1.8247 \mathrm{E}-01$ & $2.3248 \mathrm{E}+00$ & $2.1897 \mathrm{E}-01$ \\
1700.0 & F & $5.6071 \mathrm{E}-02$ & $1.7500 \mathrm{E}-01$ & $2.2296 \mathrm{E}+00$ & $2.1000 \mathrm{E}-01$ \\
1800.0 & F & $5.3695 \mathrm{E}-02$ & $1.6759 \mathrm{E}-01$ & $2.1351 \mathrm{E}+00$ & $2.0110 \mathrm{E}-01$ \\
1900.0 & F & $5.1384 \mathrm{E}-02$ & $1.6037 \mathrm{E}-01$ & $2.0433 \mathrm{E}+00$ & $1.9245 \mathrm{E}-01$ \\
2000.0 & F & $4.9167 \mathrm{E}-02$ & $1.5345 \mathrm{E}-01$ & $1.9551 \mathrm{E}+00$ & $1.8414 \mathrm{E}-01$
\end{tabular}

WORST CASE VALUES:

$\begin{array}{lllll}100.0 & A & 1.0325 E-01 \quad 3.2224 E-01 \quad 4.1055 E+00 \quad 3.8669 E-01\end{array}$ 
MAXIMUM RADIOLOGICAL CONSEQUENCES OF INHALATION:

RADIOLOGICAL DOSES:

CONTRIBUTION DUE TO U-232 $=5.9979 \mathrm{E}+02 \mathrm{rem} / \mathrm{g}$

CONTRIBUTION DUE TO U-234 $=9.7344 \mathrm{E}+03 \mathrm{rem} / \mathrm{g}$

CONTRIBUTION DUE TO U-235 $=2.4391 \mathrm{E}+02 \mathrm{rem} / \mathrm{g}$

CONTRIBUTION DUE TO U-236 $=3.7312 E+01 \mathrm{rem} / \mathrm{g}$

CONTRIBUTION DUE TO U-238 $=1.7470 E+00 \mathrm{rem} / \mathrm{g}$

TOTAL $=1.0617 \mathrm{E}+04 \mathrm{rem} / \mathrm{g}$

DOSE DUE TO INHALATION $=4.1055 \mathrm{E}+00 \mathrm{rem}$

MAXIMUN CHEMICAL CONSEQUENCES OF INHALATION:

UPTAKE DUE TO INHALATION $=3.8669 E-01 \mathrm{mg}$

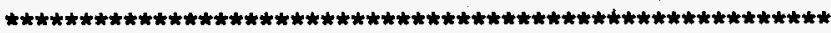

WATER TRANSPORT CALCULATIONS:

FRACTION REACHING PUBLIC DRINKING SUPPLY $=1.0000 E-02$ TANK VOLUME $=4.7317 \mathrm{E}+02 \mathrm{m3}$

DAILY WATER UPTAKE $=2.0000 \mathrm{E}-03 \mathrm{~m} 3$

MASS AVAILABLE FOR UPTAKE $=4.2268 \mathrm{E}-07 \mathrm{~kg}$

RADIOLOGICAL CONSEQUENCES OF INGESTION:

RADIOLOGICAL DOSES:

CONTRIBUTION DUE TO $U-232=1.1638 \mathrm{E}+00 \mathrm{rem} / \mathrm{g}$ CONTRIBUTION DUE TO U-234 $=1.9469 E+01 \mathrm{rem} / \mathrm{g}$

CONTRIBUTION DUE TO U-235 $=5.0814 \mathrm{E}-01 \mathrm{rem} / \mathrm{g}$

CONTRIBUTION DUE TO U-236 $=7.7734 \mathrm{E}-02 \mathrm{rem} / \mathrm{g}$

CONTRIBUT ION DUE TO U-238 $=3.3485 \mathrm{E}-03 \mathrm{rem} / \mathrm{g}$

TOTAL $=2.1222 E+01 \mathrm{rem} / \mathrm{g}$

DOSE DUE TO INGESTION $=8.9699 \mathrm{E}-03 \mathrm{rem}$

CHEMICAL CONSEQUENCES OF INGESTION:

INTAKE DUE TO INGESTION $=4.2268 \mathrm{E}-01 \mathrm{mg}$ 


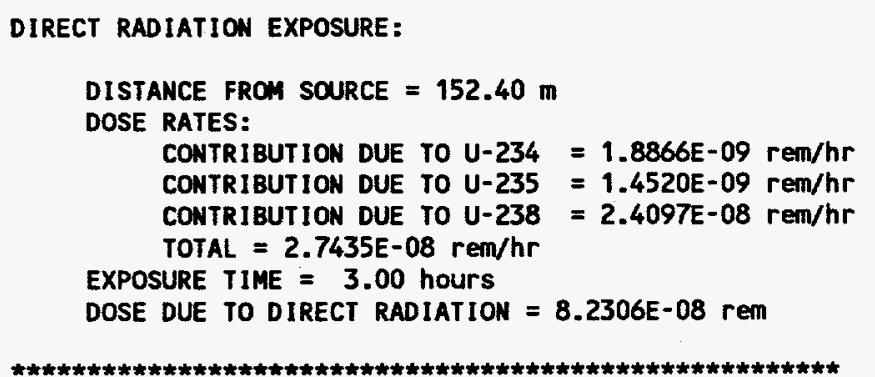

ATMOSPHERIC DISPERSION CALCULATIONS:

AMBIENT PROPERTIES: $\quad$ AMBIENT TEMPERATURE $=298.0 \mathrm{~K}$ MOLECULAR WEIGHT OF AMBIENT AIR $=28.96$ DENSITY OF AMBIENT AIR $=1.1614 \mathrm{E}+00 \mathrm{~kg} / \mathrm{m3}$ HIND VELOCITY AT $2 \mathrm{~m}=1.00 \mathrm{~m} / \mathrm{s}$

PLUME PROPERTIES:

MOLECULAR VEIGHT OF PLUME $=\mathbf{2 8 . 9 6}$

FLAME TEMPERATURE $=1200.0 \mathrm{~K}$

INITIAL PLUME RADIUS $=0.50 \mathrm{~m}$

BURN RATE $=8.9000 E-04 \mathrm{~kg} / \mathrm{s}$

INITIAL VERTICAL PLUME VELOCITY $=1.00 \mathrm{~m} / \mathrm{s}$

EQUILIBRIUM PLUME RISE $=3.6867 \mathrm{E}+01 \mathrm{~m}$

RECEPTOR INFORMATION: CROSSWIND DISTANCE $=0.0000 E+00 \mathrm{~m}$

ELEVATION OF RECEPTOR $=0.0000 E+00 \mathrm{~m}$

EXPOSURE TIME $=3.1211 \mathrm{E}+00 \mathrm{hr}$

BREATHING RATE $=1.20 \mathrm{~m} 3 / \mathrm{hr}$ $\begin{array}{cccccc}\begin{array}{c}\text { Downwind } \\ \text { Distance } \\ \text { (m) }\end{array} & \begin{array}{c}\text { Stability } \\ \text { Class }\end{array} & \begin{array}{c}\text { Concentration Concentration Inhalation } \\ \text { ¿Exposure Time } \\ (\mathrm{mg}-\mathrm{hr} / \mathrm{m} 3)\end{array} & \begin{array}{c}\text { Dose } \\ (\mathrm{rem})\end{array} & \begin{array}{c}\text { Uptake } \\ (\mathrm{mg})\end{array}\end{array}$

$(\mathrm{mg} / \mathrm{m3})$

$\begin{array}{rlllll}100.0 & \text { A } & 1.0325 E-01 & 3.2224 E-01 & 3.3800 E-02 & 3.8669 E-01 \\ 200.0 & \text { A } & 5.2527 E-02 & 1.6394 E-01 & 1.7196 E-02 & 1.9673 E-01 \\ 300.0 & \text { B } & 4.2874 E-02 & 1.3382 E-01 & 1.4036 E-02 & 1.6058 E-01 \\ 400.0 & \text { B } & 4.0805 E-02 & 1.2736 E-01 & 1.3358 E-02 & 1.5283 E-01 \\ 500.0 & \text { E } & 4.1906 E-02 & 1.3079 E-01 & 1.3719 E-02 & 1.5695 E-01 \\ 600.0 & \text { E } & 5.4997 E-02 & 1.7165 E-01 & 1.8005 E-02 & 2.0598 E-01 \\ 700.0 & \text { E } & 6.0561 E-02 & 1.8902 E-01 & 1.9826 E-02 & 2.2682 E-01 \\ 800.0 & \text { E } & 6.1264 E-02 & 1.9121 E-01 & 2.0056 E-02 & 2.2945 E-01 \\ 900.0 & \text { F } & 6.0137 E-02 & 1.8769 E-01 & 1.9687 E-02 & 2.2523 E-01 \\ 1000.0 & \text { F } & 6.4247 E-02 & 2.0052 E-01 & 2.1033 E-02 & 2.4062 E-01 \\ 1100.0 & \text { F } & 6.5887 E-02 & 2.0564 E-01 & 2.1570 E-02 & 2.4677 E-01 \\ 1200.0 & \text { F } & 6.5847 E-02 & 2.0552 E-01 & 2.1557 E-02 & 2.4662 E-01 \\ 1300.0 & \text { F } & 6.4727 E-02 & 2.0202 E-01 & 2.1190 E-02 & 2.4242 E-01 \\ 1400.0 & \text { F } & 6.2949 E-02 & 1.9647 E-01 & 2.0608 E-02 & 2.3576 E-01 \\ 1500.0 & \text { F } & 6.0798 E-02 & 1.8976 E-01 & 1.9904 E-02 & 2.2771 E-01 \\ 1600.0 & \text { F } & 5.8464 E-02 & 1.8247 \mathrm{E}-01 & 1.9140 E-02 & 2.1897 E-01 \\ 1700.0 & \text { F } & 5.6071 E-02 & 1.7500 E-01 & 1.8356 E-02 & 2.1000 E-01 \\ 1800.0 & \text { F } & 5.3695 E-02 & 1.6759 E-01 & 1.7578 E-02 & 2.0110 E-01 \\ 1900.0 & \text { F } & 5.1384 E-02 & 1.6037 \mathrm{E}-01 & 1.6822 E-02 & 1.9245 E-01 \\ 2000.0 & \text { F } & 4.9167 \mathrm{E}-02 & 1.5345 E-01 & 1.6096 E-02 & 1.8414 E-01\end{array}$

WORST CASE VALUES:

$\begin{array}{llllll}100.0 & A & 1.0325 E-01 & 3.2224 E-01 & 3.3800 E-02 & 3.8669 E-01\end{array}$

MAXIMUM RADIOLOGICAL CONSEQUENCES OF INHALATION: 
RADIOLOGICAL DOSES:

CONTRIBUTION DUE TO U-234 $=4.5427 \mathrm{E}+01 \mathrm{rem} / \mathrm{g}$

CONTRIBUTION DUE TO U-235 $=1.8293 \mathrm{E}+00 \mathrm{rem} / \mathrm{g}$

CONTRIBUTION DUE TO U-238 $=4.0153 \mathrm{E}+01 \mathrm{rem} / \mathrm{g}$

TOTAL $=8.7409 E+01 \mathrm{rem} / \mathrm{g}$

DOSE DUE TO INHALATION $=3.3800 \mathrm{E}-02 \mathrm{rem}$

MAXIMUM CHEMICAL CONSEQUENCES OF INHALATION:

UPTAKE DUE TO INHALATION $=3.8669 \mathrm{E}-01 \mathrm{mg}$

WATER TRANSPORT CALCULATIONS:

FRACTION REACHING PUBLIC DRINKING SUPPLY $=1.0000 E-02$

TANK VOLUME $=4.7317 E+02 \mathrm{m3}$

DAILY WATER UPTAKE $=2.0000 E-03 \mathrm{~m} 3$

MASS AVAILABLE FOR UPTAKE $=4.2268 \mathrm{E}-07 \mathrm{~kg}$

RADIOLOGICAL CONSEQUENCES OF INGESTION:

RADIOLOGICAL DOSES:

CONTRIBUTION DUE TO U-234 $=9.0854 E-02 \mathrm{rem} / \mathrm{g}$

CONTRIBUTION DUE TO $U-235=3.8111 \mathrm{E}-03 \mathrm{rem} / \mathrm{g}$

CONTRIBUTION DUE TO U-238 $=7.6960 \mathrm{E}-02 \mathrm{rem} / \mathrm{g}$

TOTAL $=1.7163 E-01 \mathrm{rem} / \mathrm{g}$

DOSE DUE TO INGESTION $=7.2542 \mathrm{E}-05 \mathrm{rem}$

CHEMICAL CONSEQUENCES OF INGESTION:

INTAKE DUE TO INGESTION $=4.2268 \mathrm{E}-01 \mathrm{mg}$ 
DIRECT RADIATION EXPOSURE:

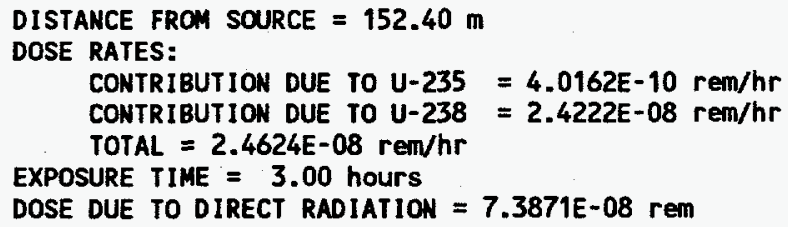

PLUME PROPERTIES:

MOLECULAR MEIGHT OF PLUME $=28.96$

FLAME TEMPERATURE $=1200.0 \mathrm{~K}$

INITIAL PLUME RADIUS $=0.50 \mathrm{~m}$

BURN RATE $=8.9000 \mathrm{E}-04 \mathrm{~kg} / \mathrm{s}$

INITIAL VERTICAL PLUME VELOCITY $=1.00 \mathrm{~m} / \mathrm{s}$

EQUILIBRIUM PLUME RISE $=3.6867 \mathrm{E}+01 \mathrm{~m}$

RECEPTOR INFORMATION: CROSSWIMD DISTANCE $=0.0000 E+00 \mathrm{~m}$

ELEVATION OF RECEPTOR $=0.0000 E+00 \mathrm{~m}$ EXPOSURE TIME $=3.1211 \mathrm{E}+00 \mathrm{hr}$ BREATHING RATE $=1.20 \mathrm{m3} / \mathrm{hr}$

\begin{tabular}{ccccc}
$\begin{array}{c}\text { Downwind } \\
\text { Distance } \\
(\mathrm{m})\end{array}$ & $\begin{array}{c}\text { Stability } \\
\text { Class }\end{array}$ & $\begin{array}{c}\text { Concentration Concentration } \\
\text { *Exposure Time } \\
(\mathrm{mg}-\mathrm{hr} / \mathrm{m} 3)\end{array}$ & $\begin{array}{c}\text { Dose } \\
\text { (rem) }\end{array}$ & $\begin{array}{c}\text { Uptake } \\
(\mathrm{mg})\end{array}$ \\
\hline
\end{tabular}

\begin{tabular}{|c|c|c|c|c|c|}
\hline $\begin{array}{r}100.0 \\
200.0 \\
300.0 \\
400.0 \\
500.0 \\
600.0 \\
700.0 \\
800.0 \\
900.0 \\
1000.0 \\
1100.0 \\
1200.0 \\
1300.0 \\
1400.0 \\
1500.0 \\
1600.0 \\
1700.0 \\
1800.0 \\
1900.0 \\
2000.0\end{array}$ & $\begin{array}{l}\mathbf{F} \\
\mathbf{F} \\
\mathbf{F} \\
\mathbf{F} \\
\mathbf{F} \\
\mathbf{F}\end{array}$ & $\begin{array}{l}1.0325 E-01 \\
5.2527 E-02 \\
4.2874 E-02 \\
4.0805 E-02 \\
4.1906 E-02 \\
5.4997 E-02 \\
6.0561 E-02 \\
6.1264 E-02 \\
6.0137 E-02 \\
6.4247 E-02 \\
6.5887 E-02 \\
6.5847 E-02 \\
6.4727 E-02 \\
6.2949 E-02 \\
6.0798 E-02 \\
5.8464 E-02 \\
5.6071 E-02 \\
5.3695 E-02 \\
5.1384 E-02 \\
4.9167 E-02\end{array}$ & $\begin{array}{l}3.2224 E-01 \\
1.6394 E-01 \\
1.3382 E-01 \\
1.2736 E-01 \\
1.3079 E-01 \\
1.7165 E-01 \\
1.8902 E-01 \\
1.9121 E-01 \\
1.8769 E-01 \\
2.0052 E-01 \\
2.0564 E-01 \\
2.0552 E-01 \\
2.0202 E-01 \\
1.9647 E-01 \\
1.8976 E-01 \\
1.8247 E-01 \\
1.7500 E-01 \\
1.6759 E-01 \\
1.6037 E-01 \\
1.5345 E-01\end{array}$ & $\begin{array}{l}1.5803 E-02 \\
8.0400 E-03 \\
6.5625 E-03 \\
6.2457 E-03 \\
6.4143 E-03 \\
8.4179 E-03 \\
9.2696 E-03 \\
9.3772 E-03 \\
9.2047 E-03 \\
9.8338 E-03 \\
1.0085 E-02 \\
1.0079 E-02 \\
9.9073 E-03 \\
9.6351 E-03 \\
9.3059 E-03 \\
8.9487 E-03 \\
8.5823 E-03 \\
8.2186 E-03 \\
7.8650 E-03 \\
7.5256 E-03\end{array}$ & $\begin{array}{l}3.8669 \mathrm{E}-01 \\
1.9673 \mathrm{E}-01 \\
1.6058 \mathrm{E}-01 \\
1.5283 \mathrm{E}-01 \\
1.5695 \mathrm{E}-01 \\
2.0598 \mathrm{E}-01 \\
2.2682 \mathrm{E}-01 \\
2.2945 \mathrm{E}-01 \\
2.2523 \mathrm{E}-01 \\
2.4062 \mathrm{E}-01 \\
2.4677 \mathrm{E}-01 \\
2.4662 \mathrm{E}-01 \\
2.4242 \mathrm{E}-01 \\
2.3576 \mathrm{E}-01 \\
2.2771 \mathrm{E}-01 \\
2.1897 \mathrm{E}-01 \\
2.1000 \mathrm{E}-01 \\
2.0110 \mathrm{E}-01 \\
1.9245 \mathrm{E}-01 \\
1.8414 \mathrm{E}-01\end{array}$ \\
\hline \multicolumn{6}{|c|}{ WORST CASE VALUES: } \\
\hline 1 & A & $=-07$ & $=-01$ & 1.380 SE-UL & 01 \\
\hline
\end{tabular}

MAXIMUM RADIOLOGICAL CONSEQUENCES OF INHALATION:

RADIOLOGICAL DOSES: 
CONTRIBUTION DUE TO U-235 $=5.0598 \mathrm{E}-01 \mathrm{rem} / \mathrm{g}$ CONTRIBUT ION DUE TO U-238 $=4.0362 E+01 \mathrm{rem} / \mathrm{g}$ TOTAL $=4.0868 \mathrm{E}+01 \mathrm{rem} / \mathrm{g}$

DOSE DUE TO INHALATION $=1.5803 E-02 \mathrm{rem}$

MAXIMUM CHEMICAL CONSEQUENCES OF INHALATION:

UPTAKE DUE TO INHALATION $=3.8669 \mathrm{E}-01 \mathrm{mg}$

MATER TRANSPORT CALCULATIONS:

FRACTION REACHING PUBLIC DRINKING SUPPLY $=1.0000 E-02$

TANK VOLUME \& $4.7317 E+02 \mathrm{~m} 3$

DAILY WATER UPTAKE $=2.0000 E-03 \mathrm{m3}$

MASS AVAILABLE FOR UPTAKE $=4.2268 \mathrm{E}-07 \mathrm{~kg}$

RADIOLOGICAL CONSEQUENCES OF INGESTION:

RADIOLOGICAL DOSES:

CONTRIBUTION DUE TO U-235 $=1.0541 \mathrm{E}-03 \mathrm{rem} / \mathrm{g}$

CONTRIBUTION DUE TO U-238 $=7.7360 \mathrm{E}-02 \mathrm{rem} / 9$

TOTAL $=7.8414 \mathrm{E}-02 \mathrm{rem} / \mathrm{g}$

DOSE DUE TO INGESTION $=3.3144 \mathrm{E}-05 \mathrm{rem}$

CHEMICAL CONSEQUENCES OF INGESTION:

INTAKE DUE TO INGESTION $=4.2268 \mathrm{E}-01 \mathrm{mg}$ 
TOTAL RADIOLOGICAL DOSES FOR SHIPMENT:

TOTAL RADIOLOGICAL DOSE DUE TO DIRECT RADIATION $=2.9144 \mathrm{E}-06 \mathrm{rem}$

TOTAL RADIOLOGICAL DOSE DUE TO INHALATION $=4.1551 E+00 \mathrm{rem}$

TOTAL RADIOLOGICAL DOSE DUE TO INGESTION $=9.0756 \mathrm{E}-03 \mathrm{rem}$ 

. 


\section{APPENDIX C}

Letters from Local Water Treatment Plants 


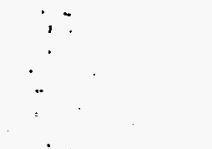

\section{KNOXVMLE UTILTIES BOARD}

September 18, 1997

Mr. Jim Anderson, Engr. Assoc.

Lockheed-Martin Eocrgy Systems

Central Engineering Services

Bldg. 1000

Mail Stop 6332

Oak Ridge, Tenn. 37831

Dear Mr. Smith:

In response to your request for information on pass-through rates of cersin particulate sizes in our filte the MBW Water Plant, we have found an average of some 5,000 particles per unl in our raw water from Teanessee River in the 2-15 micron size range. After treatment and filtration, this number will average 30 particles per $n$ in this same size range, with very feiv, if any, particles larger than this passing throutit?

Please don't hesitate to contact me if you need further information.

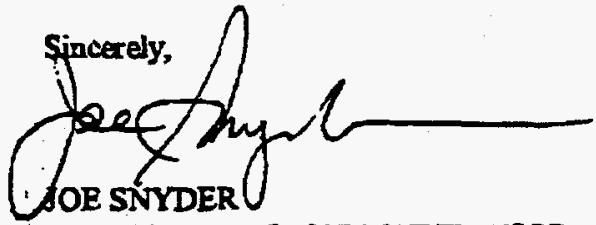

TREATMENT PLANTS SUPERVISOR

KNOXVILLE UTIITIES BOARD 


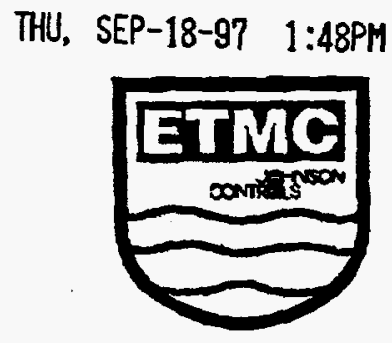

J I WATER PLANT 2412911

September 18, 1997

Mr. Jim Anderson

Enginearing Analyst

Lockheed Martin Energy Systems

FAX $\$ 576-4722$

Mr. Anderson,

The particle counting system was instalied at the D.O.EJOak Ridge Water Treatment Plant in 1995. We have fourteen fiters with particle counters on the efiluent side. Also, the clearwell which collects all the water from the firers before it goes to the customers has a particle counter. The raw water pardicle counters are beated at four locations prior to the water entering on top of the filters. We normally have very low turbidity water entering the top of the fitters and an average particle range would be 1100 per $100 \mathrm{ml}$ semple in 2-5u range, 800 5-10u. 100 10-15u $\leq 10015-25 \mathrm{u}$.

The fittered water going to the customer normally has 15 to 20 per 100 mil sample in the 2-5u range, 4 in the 5-10u range, and 0 in 10-25u.

We have taken reodings at the river intake station on the raw water in the river and the particle counts are in the 9,000 to 10,000 range. The readings at the plant on raw water particles are after chemicals have been added in the flocoulation process and most of the particles have dropped to the bottom of the sotting basin.

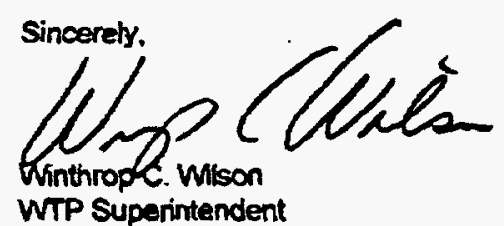

